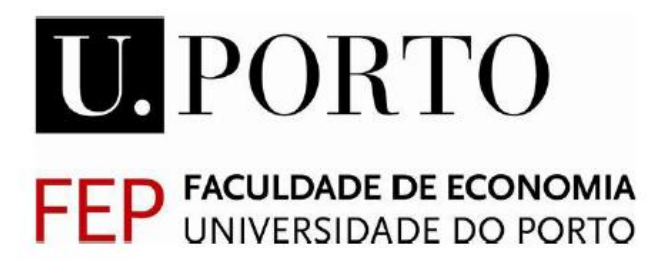

\title{
MOTIVAÇÕES NO EMPREENDEDORISMO SOCIAL
}

por

Joana Braga

Dissertação de Mestrado em Gestão de Serviços

Orientada por

Professora Doutora Teresa Proença 


\section{NOTA BIOGRÁFICA}

Joana Maria Carvalho Braga nasceu a 14 de abril de 1989, na cidade do Porto.

Em 2007 ingressou na Escola Superior de Educação do Porto para dar início à sua Licenciatura em Educação Social, que terminou no ano de 2010 com média final de 17 valores.

Em setembro desse mesmo ano, foi convidada para estagiar no Gabinete de Educação para o Desenvolvimento e Cooperação da Escola Superior de Educação do Porto.

Findo o estágio, vive uma outra experiência de estágio, a partir de novembro de 2011, numa organização não-governamental para o desenvolvimento, o Instituto de Solidariedade e Cooperação Universitária, onde acaba por permanecer até hoje como voluntária com funções de gestão e coordenação da formação.

Paralelamente ingressou em setembro de 2011 no Mestrado em Gestão de Serviços da Faculdade de Economia da Universidade do Porto, tendo terminado a parte curricular com média de 17 valores.

Em outubro de 2012, inicia um estágio na área de Marketing e Comunicação da empresa eact, Empresa Activa, onde ainda atualmente vai dando apoio pontual e desenvolvendo novos projetos. 
Here's to the crazy ones. The misfits. The rebels. The troublemakers. The round pegs in the square holes.

The ones who see things differently. They're not fond of rules. And they have no respect for the status quo. You can quote them, disagree with them, glorify or vilify them.

About the only thing you can't do is ignore them. Because they change things. They invent. They imagine. They heal. They explore. They create. They inspire. They push the human race forward.

Maybe they have to be crazy.

While some see them as the crazy ones, we see genius. Because the people who are crazy enough to think they can change the world, are the ones who do.

Steve Jobs 


\section{AGRADECIMENTOS}

Agradeço, em primeiro lugar, à minha orientadora, a Professora Doutora Teresa Proença, pelos ensinamentos, as críticas, a motivação e por acreditar em mim.

Aos meus pais, por fazerem de mim quem sou hoje, pelo amor e pela força que sempre me deram, por todo o esforço. À Ana, pelo grande apoio que me deu, em tudo.

Ao Carlos, pelo carinho, paciência, ajuda e por estar sempre presente.

A todos os Professores do Mestrado em Gestão de Serviços, em particular à Professora Doutora Teresa Fernandes por tudo que me ensinou e pelo apoio que sempre nos deu.

À Professora Doutora Catarina Roseira e Professora Doutora Luísa Pinto pelos conselhos, as críticas e disponibilidade.

Às pessoas do ISU, por tudo que me têm ensinado e em especial à Teresa Martins e ao Filipe Martins pelas oportunidades e experiências que vivencio e onde aprendo tanto.

A toda a minha família, pelo apoio, força e todos os momentos que me proporcionaram, em particular aos meus avós, por contribuírem sempre para quem sou hoje.

A todos os meus amigos, em particular, à Mariana, Cláudia, Luís, Rita, Isabel e Sara pela amizade e pelas palavras de incentivo neste meu desafio.

Às amigas do Maria Rapaz, pela compreensão, pela confiança e pela falta de tempo que tive.

À Rita Garcia, companheira de percurso, pela amizade e pela força e positivismo que põe em tudo. À Marisa Fernandes, pelo apoio, partilha e momentos de trabalho passados.

Aos professores da ESE, que tanto me ensinaram e fizeram crescer.

À Caroline e Helena da eact, pela oportunidade, experiência e compreensão, por fazerem de mim parte da vossa equipa. 
Ao Instituto de Empreendedorismo Social, em especial ao Tiago Ferreira, pela ajuda prestada e pela cedência dos contactos.

Um agradecimento muito especial a 13 empreendedores sociais sem as quais este trabalho não seria possível.

Ao Miguel Neiva, por colorir o mundo de todos.

Ao Frederico Fezas Vital, por realizar os sonhos impossíveis.

À Teresa Branco, pelo aconchego dos mais novos e companhia dos mais velhos.

Ao Abílio Cunha, por acreditar que somos todos diferentes.

À Filipa Palha, por acreditar em todos e fazê-los sorrir.

Ao Jorge Oliveira, por acreditar na diversidade e na arte.

À Ana Ferreira, por cuidar dos mais pequenos.

À Paula França, pela dedicação aos sem-abrigo.

Ao Pedro Teiga, por cuidar dos nossos rios.

Ao Sérgio Vide, por acompanhar as pessoas e acreditar nos jovens.

À Inês Santos Silva, por acreditar no potencial empreendedor de cada um.

À Ana Quintas, pelos mimos que ensina aos mais novos.

À Ana Reis, por partilhar memórias, tradições e juntar comunidades.

A todos, por acreditarem que podem mudar o mundo. 


\section{RESUMO}

É inegável a importância que o empreendedorismo social tem atualmente na sociedade e a relevância que os empreendedores sociais estão a ter a nível de impacto social. A forma como estão atentos aos que os rodeia, quer na sua vida pessoal, quer na sua atividade profissional, permite-lhes detetar necessidades sociais para as quais ainda não existem soluções ou as mesmas não têm obtido sucesso e assim, marcarem a diferença quer na procura de soluções alternativas ou inovadoras para os problemas já existentes, quer na forma como encaram o seu trabalho, com as suas competências e características de resiliência, paixão e crença de que é possível mudar o mundo.

A presente dissertação tem como principal objetivo explorar as motivações que levam os indivíduos a criarem, desenvolverem e se manterem num projeto de empreendedorismo social, bem como explorar os principais obstáculos enfrentados e as expectativas dos empreendedores sociais face à criação do seu empreendimento.

Esta investigação tem por base um estudo exploratório que incorporou a recolha e análise de dados qualitativos, envolvendo a realização de treze entrevistas a empreendedores sociais com projetos muito diversificados.

$\mathrm{O}$ estudo fornece informação sobre as motivações que levam os indivíduos a iniciarem e se manterem num projeto social, destacando-se o altruísmo, a paixão, a influência de role models, as experiências de voluntariado anteriormente vividas e a vontade de criar e inovar. A mobilização de recursos financeiros e humanos, bem como alguma burocracia, são os obstáculos mais frequentes no processo de criação do empreendimento social, mas a vontade de lutar, a persistência e a paixão que os entrevistados demonstram, ou seja, a sua motivação, parece ser o mote para continuar a lutar pelos seus objetivos.

Palavras-chave: Empreendedorismo Social; motivações; obstáculos; competências 


\section{ABSTRACT}

It is undeniable the importance that social entrepreneurship has in today's society and the role social entrepreneurs play in the social impact.

The way they see what surrounds them, either in their personal or professional life, allows them to detect social needs for which still do not exist solutions or those solutions have not obtained success yet, either by making a difference in the search of alternative or innovatory solutions for the already existent problems, or by the way they face their work, with their competencies and characteristics of resilience, passion and belief that it is possible to change the world.

The main purpose of this dissertation is to explore the factors that motivate people to create, develop and maintain a social entrepreneurship project and also to explore the principal difficulties and expectations social entrepreneurs have in the process.

This investigation is based on an exploratory study that included the collection and analysis of qualitative data, involving 13 interviews to social entrepreneurs with different types of projects.

The study provides information about the motivations that take individuals to initiate and maintain a social project, standing out the altruism, the passion, the influence of role models, volunteering experiences previously lived and the willing to create and innovate. The mobilization of financial and human resources, as well as the burocracy, are the most frequent difficulties in the process of social venture creation but the will to fight, the persistence and the passion the interviewers have, it means, their motivation, seems to be the motto for continuing to battle for their goals.

Key-words: Social entrepreneurship; motivations; difficulties; competences 


\section{INDICE}

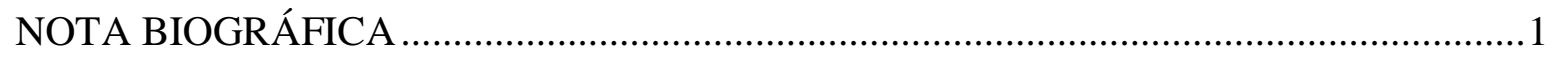

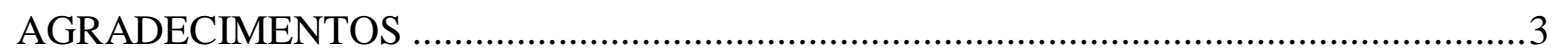

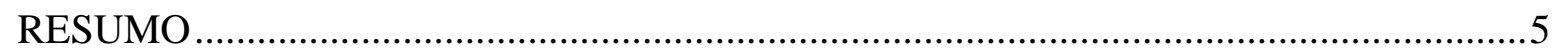

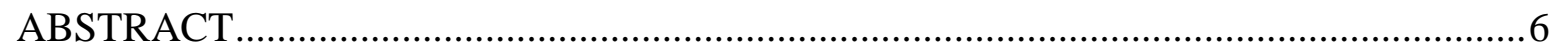

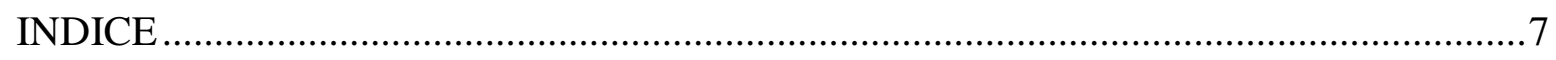

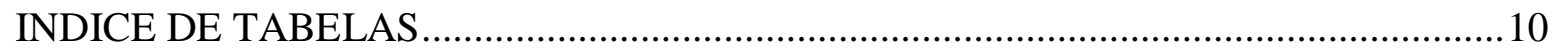

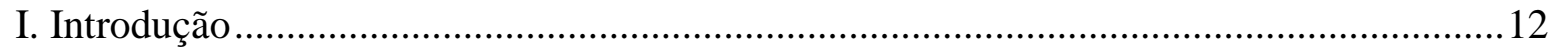

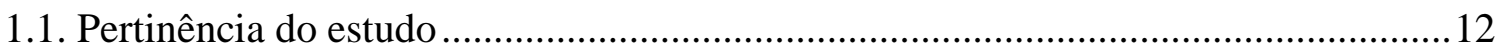

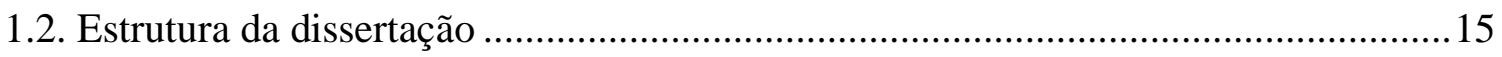

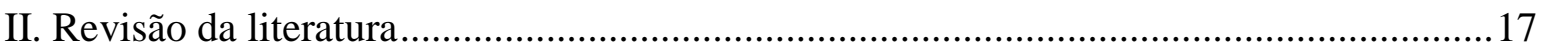

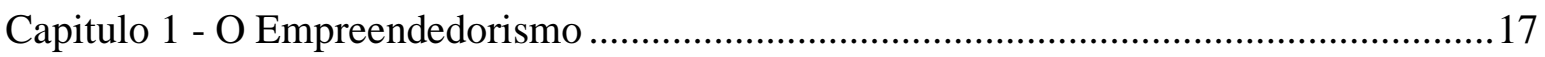

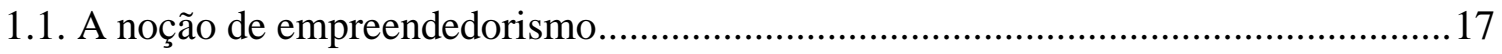

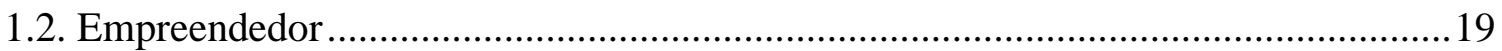

Capítulo 2 - Motivações no empreendedorismo ..........................................................22

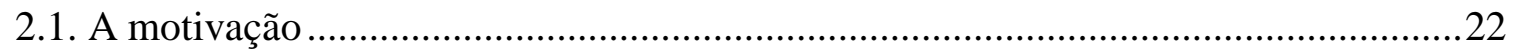

2.2. Teorias da motivação aplicadas ao empreendedorismo........................................23

2.2.1. Teorias da motivação de conteúdo..............................................................23

2.2.2. Teorias da motivação de processo .............................................................2 27

Capítulo 3- O Empreendedorismo Social .............................................................. 31

3.1. A noção de Empreendedorismo Social ............................................................ 31

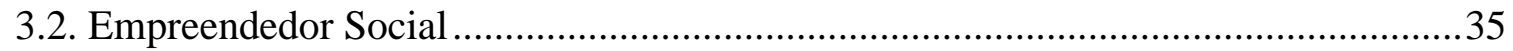




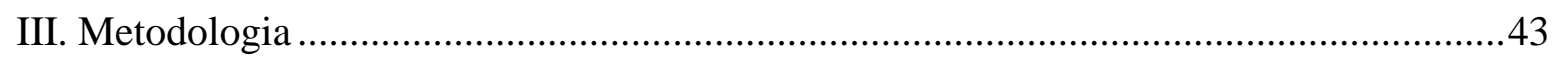

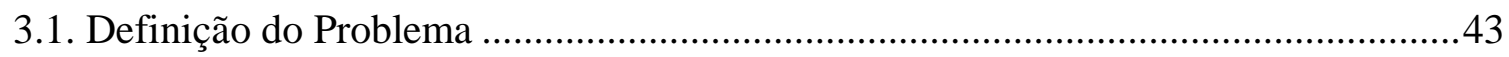

3.2. Estratégia metodológica de investigação ......................................................................45

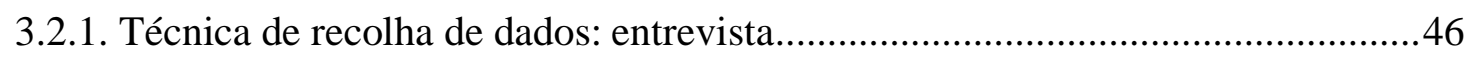

3.2.2. Procedimento para a recolha de dados............................................................50

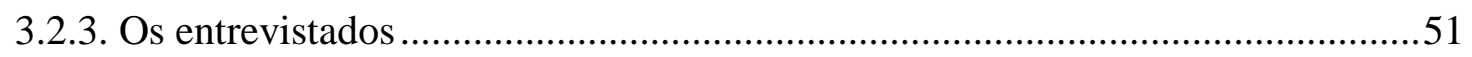

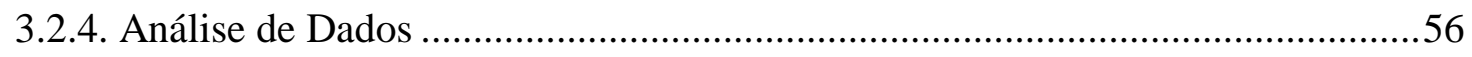

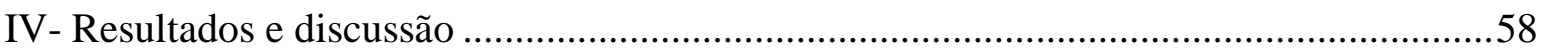

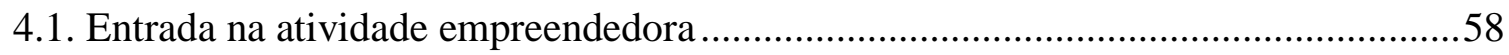

4.1.1. Fatores que despoletam o Empreendedorismo Social ........................................58

4.1.2. Envolvimento em iniciativas empreendedoras anteriormente .............................59

4.1.3. Modo de financiamento do projeto .................................................................60

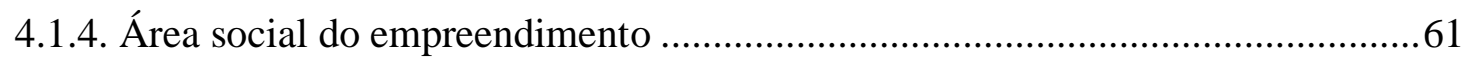

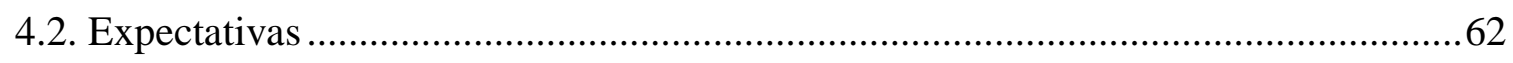

4.2.1. Expectativas de ter empreendimento próprio …………......................................62

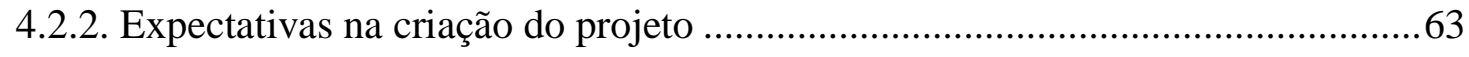

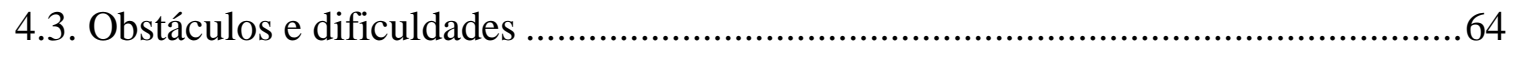

4.3.1. Obstáculos enfrentados na criação do empreendimento social.............................64

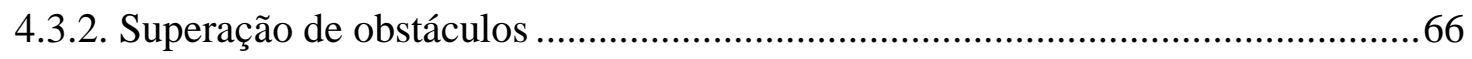

4.3.3. Preparação para enfrentar obstáculos...................................................................67

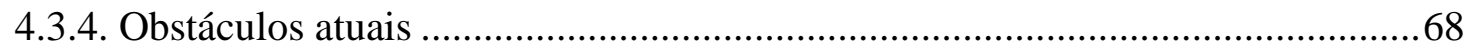

4.3.5. Superação dos obstáculos atuais ....................................................................69

4.3.6. Impacto dos obstáculos na motivação de um potencial empreendedor social....70 
4.4. Sucesso na perspetiva do empreendedor social .70

4.4.1. Sucesso como percurso individual........................................................ 71

4.4.2. Competências e capacidades do empreendedor social .....................................72

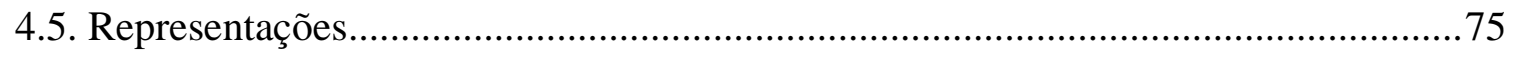

4.5.1. Diferenças entre empreendedorismo social e empreendedorismo comercial .....75

4.5.2. Representação de si próprio: Criatividade e inovação ....................................77

4.5.3. Aspetos positivos e negativos de ser um empreendedor social ........................78

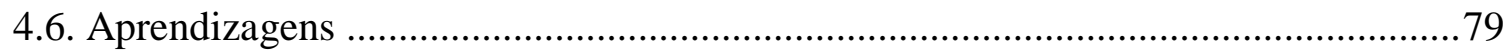

4.6.1. Recomendações a potenciais empreendedores sociais ..................................79

4.6.2. Mudanças na vida dos empreendedores sociais........................................... 80

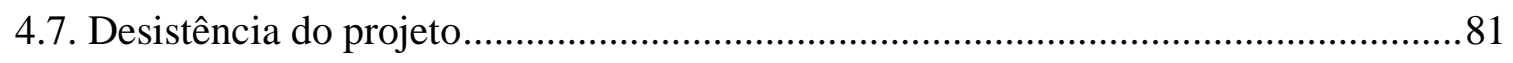

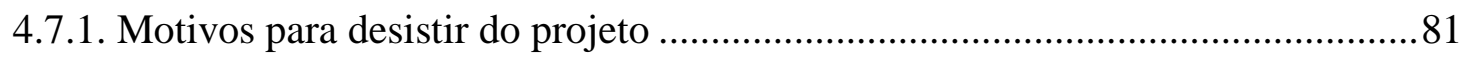

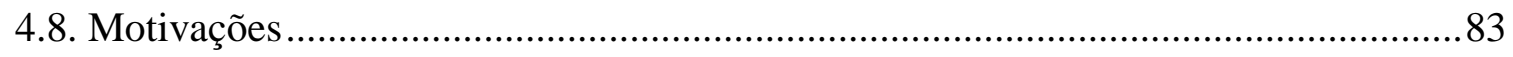

4.8.1. Motivações na criação do empreendimento social .........................................83

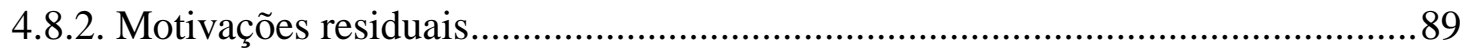

4.8.3. Alteração nas motivações ao longo do tempo .................................................93

4.8.4. Diferença nas motivações na criação de um empreendimento comercial e social

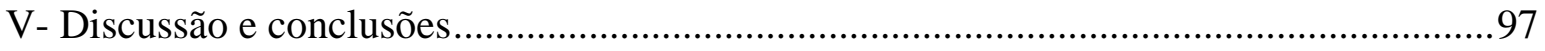

5.1. - Motivação dos indivíduos a iniciarem um empreendimento de âmbito social .......97

5.2. - Diferenças entre as motivações para o empreendedorismo social e as motivações para o empreendedorismo tradicional .................................................................99

5.3. - O impacto da motivação no processo de desenvolvimento do projeto, nomeadamente, quais são os obstáculos, expectativas e alteração nas motivações ao

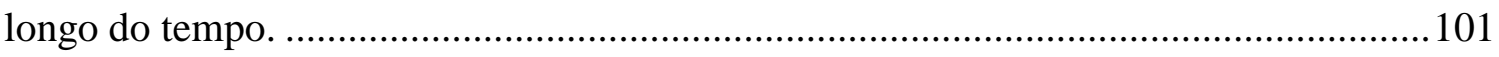

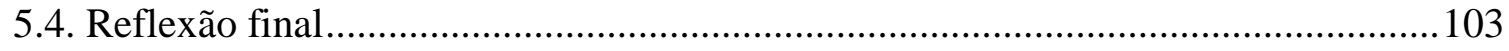


5.5. Limitações do estudo e sugestões para investigações futuras

Bibliografia 106

Anexos 115

Guião de entrevista 115

\section{INDICE DE TABELAS}

Tabela 1 - Características psicológicas dos empreendedores

Tabela 2 - Categorias de motivações no empreendedorismo.........................................22

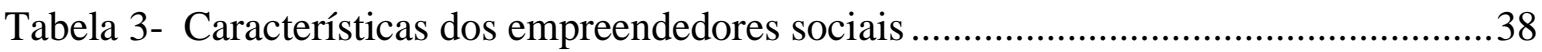

Tabela 4 - Diferenças entre empreendedorismo comercial e empreendedorismo social ......42

Tabela 5 - Dimensões de análise do estudo e respetivas questões do guião de entrevista ...50

Tabela 6 - Empreendedores sociais entrevistados e respetivos projetos..........................54

Tabela 7 - Perfil demográfico e profissional dos entrevistados ........................................55

Tabela 8 - Envolvimento dos entrevistados em iniciativas empreendedoras .....................60

Tabela 9 - Expectativas de ter empreendimento próprio $(\%)$..........................................63

Tabela 10 - Obstáculos dos empreendedores sociais na criação do empreendimento..........66

Tabela 11 - Obstáculos atuais enfrentados pelos empreendedores sociais .....

Tabela 12 - Perceção dos entrevistados das competências necessárias ao empreendedor social para obter sucesso

Tabela 13 - Aspetos positivos e negativos de ser um empreendedor social

Tabela 14 - Recomendações dos entrevistados a um potencial empreendedor social .80

Tabela 15 - Mudanças nos entrevistados enquanto empreendedores sociais .81

Tabela 16 - Motivos para desistir do empreendimento social 
Tabela 17 - Motivações dos empreendedores sociais na criação do empreendimento social .

Tabela 18 - Motivações na criação do empreendimento social ................................................98

Tabela 19 - Diferenças e semelhanças nas motivações entre empreendedorismo comercial e

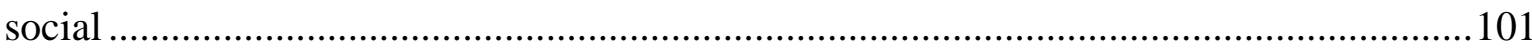




\section{Introdução}

\subsection{Pertinência do estudo}

Este estudo, focado nas motivações no empreendedorismo social, reveste-se de enorme importância para a temática do empreendedorismo, o qual tem hoje um papel marcante na sociedade, contribuindo para o crescimento dos serviços, para a promoção do emprego a nível nacional, para a inovação e mudanças tecnológicas gerando, desta forma, crescimento económico e maior bem-estar social (Schumpeter, 1934 cit. Shane et al, 2003).

Certo e Miller (2008) definem o empreendedorismo social como um processo que envolve o reconhecimento, avaliação e exploração de oportunidades que resultam em valor social, por oposto à criação de riqueza pessoal ou dos acionistas e este valor social não está relacionado com lucros, mas envolve sim a satisfação de necessidades básicas como a entrega de alimentos, água, saúde, educação e serviços médicos. O empreendedorismo social combina os benefícios do empreendedorismo com a resolução de objetivos sociais e ambientais e tem potencial para assistir os indivíduos económica e socialmente em todas as comunidades no mundo (Haugh, 2007).

A capacidade dos indivíduos e comunidades para se auto-organizarem em grupos e associações, de forma a providenciar os bens e serviços necessários, sempre foi uma preocupação ao longo do tempo. Contudo, a emergência de aventuras sociais empresariais que procuram uma sustentabilidade financeira apenas recentemente recebeu atenção dos académicos. Na verdade a investigação em empreendedorismo tem dado pouca atenção aos processos de empreendedorismo no contexto social (Shaw \& Carter, 2007). Segundo Seelos e Mair (2005, p.243), “a falta de teoria em empreendedorismo social constitui uma barreira ao reconhecimento e a um suporte mais focado que permita que estas iniciativas cresçam de forma significativa e que atinjam uma escala em que possam realmente constituir uma diferença para a erradicação da pobreza em todas as suas formas”. Este conhecimento tem necessidade de ser construído para que os governantes possam saber gerir a melhor forma de definir políticas que promovam a criação e o desenvolvimento de novas empresas 
(Rubio et al, s/d). Para além deste argumento, outros existem, que nos levam a querer explorar melhor o empreendedorismo social.

Em primeiro lugar, o crescimento do empreendedorismo social providencia uma oportunidade única de desafiar, questionar e repensar determinados conceitos e teorias relativas ao empreendedorismo comercial, no sentido de se poder analisar a construção de um paradigma comum (Mair \& Noboa, 2005). O número de empreendedores sociais têm aumentado significativamente nos últimos anos e as suas atividades e organizações já não são vistas como menos importantes do que as atividades dos empreendedores comerciais; em vez disso, elas são percebidas como de enorme importância na sociedade contemporânea (Steinerowski et al, 2008). Por exemplo, mais de $2 \%$ da população adulta ativa nos Estados Unidos, Reino Unido ou Finlândia está envolvida num negócio social (Harding, 2006 cit. Rubio et al, s/d).

Em segundo, é inegável a importante contribuição que os empreendedores sociais têm tido a nível social, cultural e ambiental. Num ambiente em que as instituiçõos, o próprio Estado e organizações de voluntariado têm sido tão criticados pela sua resistência à mudança e burocracias que envolvem, e onde o setor público se encontra sobrecarregado, o empreendedorismo social representa a maneira inovadora de dar resposta a determinadas necessidades económicas e sociais (Mulgan \& Landry, 1995; Leadbeater, 1997, cit. Shaw \& Carter, 2007). Em boa medida, o empreendedorismo social funciona como um mecanismo de suporte à atividade económica e tem sido a força do crescimento do setor social (Rubio et al, s/d). De facto, os empreendedores sociais identificam oportunidades que vêm dar resposta a falhas do mercado e oferecem soluções criativas e inovadoras para os problemas sociais das comunidades.

Terceiro, embora exista já algum trabalho que procura diferenciar o empreendedorismo social de outras formas de organização com o intuito de melhor o definir, um dos aspetos que continua a ser ignorado são os seus antecedentes motivacionais pelo que é necessário continuar a explorar as múltiplas motivações que sustentam este complexo fenómeno (Miller et al, 2012). Movimentos que procurem compreender a motivação de alguém para criar mudança social são de enorme relevância para o estudo do empreendedorismo social (Mair \& Martí, 2006). Ademais, o estudo das motivações para o 
empreendedorismo é crítico para o estudo de outras áreas do empreendedorismo, como sendo as cognições, as intenções e os comportamentos empreendedores (Carsrud \& Brannback, 2011).

Em quarto, alguns estudos que exploram as motivações para o empreendedorismo, têm apenas em conta as motivações para iniciar um negócio; contudo, o empreendedorismo é um processo dinâmico e as motivações podem mudar ao longo do tempo (Littunen, 2000 cit. Hessels et al, 2008) pelo que faz falta investigação que procure compreender estas possíveis mudanças (Hessels et al, 2008; Shane et al, 2003), e sobretudo no domínio do empreendedorismo social.

A importância de estudar as motivações aumenta ainda mais se tivermos em conta que o tipo de motivação que um indivíduo tem pode determinar os objetivos e metas da empresa (Hessels et al, 2008). Corroborando esta ideia, Shane et al (2003) referem que as decisões que as pessoas tomam ao longo do processo de empreendedorismo e o sucesso que relatam são influenciados pela vontade das mesmas para entrar neste "jogo". Isto significa que as motivações humanas influenciam a forma como as pessoas vão procurar oportunidades, explorar recursos e a forma como levam a cabo o processo de empreenderem (Shane et al, 2003), pelo que estudar as suas motivações é de enorme importância se quisermos compreender por exemplo, de que forma motivar as pessoas para serem mais empreendedoras (Shane et al, 2003).

Por último, é ainda importante referir que o facto de se estudar o empreendedorismo social do ponto de vista do empreendedor (enquanto pessoa) e não ao nível organizacional (instituições) torna-se muito pertinente pelo facto de existirem poucos estudos que foquem o empreendedor social. Embora existam diversos estudos sobre a personalidade do empreendedor, a maioria da investigação existente na área tem-se focado essencialmente ao nível institucional (Aldrich, 2000), pelo que alguns autores sugerem um foco no indivíduo (de Bruin et al, 2007). Isto parece particularmente importante quando se fala de motivações para o empreendedorismo (Shane et al, 2003; Kirkwood, 2009), mais concretamente com a compreensão do papel da ação humana (Shane et al, 2003).

Desta forma, o objetivo desta investigação é explorar as motivações que levam os indivíduos a criarem, desenvolverem e se manterem num projeto de empreendedorismo ou 
seja, explorar o que as pessoas pretendem alcançar com o empreendimento e explorar os processos/dinâmicas motivacionais para a construção do mesmo, isto é, as expetativas iniciais, os apoios que procuraram obter, os obstáculos enfrentados, o que aconteceu de diferente em relação ao esperado, entre outros que possam ser relevantes.

Esta investigação é também o fruto da paixão do investigador pela área social e pelo empreendedorismo. O conhecimento pessoal de alguns empreendedores sociais suscita curiosidade, admiração e fascínio pelo seu trabalho e pelas suas ideias.

Por fim, espera-se com este estudo poder contribuir para o conhecimento sobre o empreendedorismo social, nomeadamente as motivações dos indivíduos para ingressarem nesta aventura e espero poder desenvolver novos contributos na área, estabelecendo novas ideias para futuras investigações.

\subsection{Estrutura da dissertação}

A dissertação encontra-se organizada em cinco capítulos.

No primeiro capítulo, a introdução, é explicada a importância que o empreendedorismo social tem atualmente e a pertinência da investigação na área e concretamente nas motivações no empreendedorismo social.

No segundo capítulo é efetuado o enquadramento teórico do tema de investigação, sendo explorado o conceito de empreendedorismo e exploradas as características do empreendedor comercial e as respetivas motivações, no sentido de enquadrar, posteriormente, o empreendedorismo social. Neste sentido, é também explorado este conceito, confrontando com o anterior, bem como as características do empreendedor social e lançam-se já algumas pistas que nos poderão levar a compreender as motivações do empreendedor social.

No terceiro capítulo, apresentam-se as questões de investigação, assim como a metodologia de investigação utilizada, e respetiva recolha e análise dos dados bem como a apresentação dos entrevistados deste estudo.

No quarto capítulo são apresentados os resultados e sua respetiva análise. 
No quinto e último capítulo é feita a discussão dos resultados e apresentadas as conclusões da pesquisa. São ainda sintetizadas as principais contribuiçõos do estudo, indicadas as limitações desta pesquisa e, por fim, sugerem-se orientações para futuras investigações. 


\section{Revisão da literatura}

No início deste capítulo começa-se por explicar o que é o empreendedorismo tradicional já que os empreendedores sociais constituem um subtipo de empreendedores (Dees, 1998; Certo \& Miller, 2008) que diferem na sua missão e na forma como iniciam os seus negócios, particularmente no que diz respeito às suas motivações para se tornarem empreendedores (Mair \& Noboa, 2005). Posteriormente são abordadas as motivações no empreendedorismo porque uma vez que existe pouca investigação na área das motivações para o empreendedorismo social, é necessário basear-me na literatura existente nas motivações para o empreendedorismo comercial ou convencional (Dacin et al, 2010).

\section{Capitulo 1 - O Empreendedorismo}

\subsection{A noção de empreendedorismo}

"This is the entrepreneurial age. Entrepreneurs are driving a revolution that is transforming and renewing economies worldwide. Entrepreneurship is the essence of free enterprise because the birth of new businesses gives a market economy its vitality. New and emerging businesses create a very large proportion of the innovative products and services that transform the way we work and live" (Bygrave \& Zacharakis, 2011, p.1).

O empreendedorismo "é o processo de criar algo novo com valor, dedicando o tempo e o esforço necessários, assumindo os riscos financeiros, psíquicos e sociais correspondentes e recebendo as consequentes recompensas da satisfação e da independência financeira e pessoal" (Hisrich, Peters e Shepherd, 2010, p.30).

Ele envolve a ligação entre dois fenómenos: a criação de oportunidades lucrativas e a presença de indivíduos empreendedores (Venkataraman, 1997 cit. Shane \& 
Venkataraman, 2000), pelo que não podemos definir o empreendedorismo tendo em conta apenas um deles, mas sim os dois.

Implica, por isso, a descoberta, a avaliação e exploração de oportunidades, ou seja, de novos produtos e/ou serviços ou processos de produção, novas estratégias e formas de organização e de novos mercados com diversos inputs que antes não existiam (Shane \& Venkataraman, 2000). Ou seja, é um processo que envolve o reconhecimento destas oportunidades mas também o ser capaz de as converter em ideias vendáveis, através do dispêndio de tempo, esforço, dinheiro, competências e assunção de riscos associados às mesmas (Drost, 2012).

Importa salientar que o empreendedorismo "caracteriza tipicamente uma empresa em que um ou mais acionistas que detêm os ativos da firma ficam com os lucros ou reinvestem-nos" (Whitman, 2011, p.570). O resultado final é a criação de novo valor para os clientes, quer este seja económico, social, ambiental ou uma combinação de vários (Thompson \& Doherty, 2006).

Resumindo, o empreendedorismo inclui todas as funções, atividades e ações associadas com a perceção de oportunidades e a criação da organização para as levar a cabo (Krueger \& Brazeal, 1994; Shane et al, 2003; Bygrave \& Zacharakis, 2011). Por tudo isto, e tendo especialmente em conta a forma como os empreendedores mobilizam os recursos de forma inovadora, é possível afirmar que o empreendedorismo é um processo criativo (Shane et al, 2003). Também é um processo que envolve conhecimento, informação, inovação, mudança, descoberta, desenvolvimento, movimento, ação, risco, incerteza e exploração (Acs \& Audretsch, 2002 cit. Steinrowski et al, s/d) independentemente destas características se traduzirem na criação de uma nova organização ou de simplesmente ocorrer no interior de uma já existente.

Este processo tem início, como já foi referido, com o reconhecimento de uma oportunidade e segue-se o desenvolvimento de uma ideia para perseguir essa oportunidade, a avaliação da viabilidade da oportunidade, o desenvolvimento do produto ou serviço que será entregue ao cliente, a junção dos recursos humanos e financeiros necessários, o planeamento organizacional e a procura de clientes (Shane et al, 2003). 
Tal como já foi referido, o empreendedor é considerada a principal força do processo empreendedor (Shane et al., 2003). O processo de empreendedorismo ocorre porque as pessoas perseguem as oportunidades e, como as pessoas são diferentes, a sua capacidade e habilidade para agir sobre as mesmas também o são (Shane et al, 2003). Posto isto, importa agora fazer uma breve referência à principal literatura sobre o empreendedor.

\subsection{Empreendedor}

"[to creat a new venture] For that we need a person, in whose mind all of the possibilities come together, who believes that innovation is possible, and who has the motivation to persist until the job is done" (Naffziger, Hornsby \& Kuratko, 1994, p.29)

Joseph Schumpeter (1934) apresentou-nos, no século 20, uma definição moderna de empreendedor como sendo o indivíduo que destrói a ordem na economia existente ao introduzir novos produtos e serviços, novos métodos de produção, através da criação de novas formas de organização ou pela exploração de novas matérias-primas. Segundoo mesmo autor, é mais provável que esta "destruição" passe pela criação de um novo negócio, mas também pode passar pela inovação num já existente (Schumpeter, 1934).

No seu livro "Empreendedorismo", ByGrave e Zacharakis (2011) definem o empreendedor como sendo a pessoa que percebe uma oportunidade e cria uma organização para a atingir, o que parece ser uma definição unânime para vários autores. Outros autores acrescentam ainda que o empreendedor é um indivíduo que é capaz de identificar e/ou criar oportunidades e inovações e mobilizar recursos que o permitam tirar o máximo de benefícios dessa inovação (Thompson, 2004; Marques et al, 2012).

Os empreendedores podem perseguir as oportunidades em qualquer indústria e a qualquer momento. Eles podem ser encontrados em grandes ou pequenas empresas, quer no setor público ou privado, na procura pela mudança e marcando a diferença (Thompson, 2004). Por exemplo, alguns empreendedores construíram empresas inovadoras de sucesso, 
contribuindo assim para a criação de uma nova indústria, outros construíram novas empresas em indústrias maduras (Shane et al, 2003).

Podemos então falar de empreendedores que revolucionaram o mundo dos negócios, como Bill Gates (Microsoft), ou Jeffrey Bezos (Amazon) ou de empreendedores que entram em mercados já existentes mas com ideias ou formas de gestão inovadoras como Sam Walton (Walmart). A questão é que todos eles perseguem uma oportunidade, criam valor com ela, inovam, correm pelos seus sonhos. E todos eles possuem uma "atitude de alguém que preza a sua independência e realização pessoal" (Guia Prático do Empreendedor, 2012, p.2). Ademais, "Detetar uma oportunidade e possuir o conhecimento, criatividade e iniciativa para, isoladamente ou em conjunto, enfrentar a incerteza e transformar essa oportunidade em criação de valor, são as características fundamentais de um empreendedor" (Guia Prático do Empreendedor, 2012, p.2).

Diferentes autores têm procurado estudar as características que definem um empreendedor alegando que estas possuem influência numa maior propensão para o empreendedorismo. Nas leituras efetuadas, características como a autonomia, a criatividade e a inovação são constantemente referidas; também se considera que o empreendedor tem uma certa propensão para o risco, isto é, é alguém que está disposto a se comprometer, que gosta de desafios e que não se importa de correr riscos. Defende-se também que o empreendedor é alguém com capacidade de liderança, que acredita nas suas capacidades e possui elevada autoestima. Por isso, acredita que é capaz de controlar os seus próprios objetivos e comportamentos, tendo por isso sido identificado como tendo locus de controlo interno ${ }^{1}$. Por fim, é alguém que possui uma elevada necessidade de realização e que vê no empreendedorismo um meio para a alcançar. As características do empreendedor apresentam-se compiladas na tabela 1.

\begin{tabular}{|c|c|}
\hline \multicolumn{2}{|c|}{ Características psicológicas dos empreendedores } \\
\hline Características & Autores \\
\hline
\end{tabular}

\footnotetext{
${ }^{1}$ Indivíduo sente que tem controlo sobre os seus próprios comportamentos, ou seja, uma pessoa que tenha um locus de controlo predominantemente interno sente que tem controlo sobre a sua própria vida e sucesso, exigindo mais de si mesmo e lida com os seus próprios problemas atuais.
} 


\begin{tabular}{|l|l|}
\hline Autonomia & McClelland (1961); Douglas (1999). \\
\hline Criatividade & Kourilsky (1980); Hisrich et al. (2004). \\
\hline Inovação & $\begin{array}{l}\text { McClelland (1961); Miner (1990); Koh (1996); Hisrich et al. } \\
\text { (2004); Marques et al. (2011a, b). }\end{array}$ \\
\hline Locus controlo interno & Kourilsky (1980); Bygrave (1989); Kobia \& Sikalieh (2010). \\
\hline $\begin{array}{l}\text { Necessidade de } \\
\text { realização }\end{array}$ & $\begin{array}{l}\text { McClelland (1961); Kourilsky (1980); Bygrave (1989); Hisrich } \\
\text { et al. (2004); Kobia \& Sikalieh (2010). }\end{array}$ \\
\hline $\begin{array}{l}\text { Competências de } \\
\text { liderança e organização }\end{array}$ & Hornaday \& Aboud (1971); Hisrich et al. (2004). \\
\hline Propensão para o risco & $\begin{array}{l}\text { McClelland (1961); Bygrave (1989); Begley (1995); } \\
\text { Brandstatter (1997); Van Praag \& Cramer (2001); Kobia \& } \\
\text { Sikalieh (2010). }\end{array}$ \\
\hline Confiança & $\begin{array}{l}\text { Kourilsky (1980); Hisrich et al. (2004); Marques et al. (2011a, } \\
\text { b). }\end{array}$ \\
\hline Auto-estima & Hisrich et al. (2004); Marques et al. (2011b). \\
\hline
\end{tabular}

Tabela 1 - Características psicológicas dos empreendedores

Fonte: Elaboração própria

Ser um empreendedor, do ponto de vista de gerir ou criar a sua própria empresa ou projeto é então um desafio pessoal que muitos preferem ao invés de trabalhar para outrem. É aceitar correr riscos financeiros pessoais que ter um negócio próprio acarreta, mas também beneficiar diretamente do potencial sucesso do negócio (Segal et al, 2005). Ser empreendedor é, muitas das vezes, ser visto como alguém que opta por uma carreira de risco e ser confrontado diariamente na sua empresa com situações de trabalho repletas de incerteza, impedimentos, falhanços e frustrações associadas ao processo de criação de uma nova empresa (Campbell, 1992 cit. Segal et al, 2005).

Assim, isto leva a que os investigadores tenham vindo a procurar explorar o que motiva os indivíduos a tornarem-se empreendedores, o que os leva a assumir os riscos e incertezas de criar uma empresa, ou seja, ao estudo das motivações no empreendedorismo. 


\section{Capítulo 2 - Motivações no empreendedorismo}

\subsection{A motivação}

A motivação representa uma ponte importante entre a intenção e a ação, o que significa que os objetivos e as motivações desempenham um papel importante na previsão do comportamento humano, especialmente no comportamento empreendedor (Bird \& Schjoedt cit. Carsrud \& Brannback, 2011).

A motivação, usada para explicar o esforço e a persistência sobre uma dada ação (Kanfer, 1990 cit. Hechavarria et al, 2012), desempenha um papel importante na criação de novas organizações (Segal et al., 2005) uma vez que influencia a tomada de decisão, inclusive aquela a que se refere à criação de um novo negócio (Shane et al., 2003). Mais concretamente, a motivação influencia o comportamento empreendedor de três formas: influencia na escolha do individuo, ou seja, a direção da ação; influencia a intensidade da ação, baseada na importância, no valor que a ação possui para o empreendedor e influencia a persistência da ação (Locke, 2000).

De facto, as empresas não nascem por elas próprias...alguém, um empreendedor, toma uma decisão consciente e compromete-se com tempo e recursos nesta nova aventura. Tendo isto em conta, bem como os riscos associados a este processo, parece óbvio que os indivíduos que a ele se propõe, possuem uma grande motivação para o fazer (Hechavarria et al, 2012; Dunkelberg et al, 2012).

Se pensarmos que o ser humano é tão diverso, é claro afirmar que também as motivações diferem de pessoa para pessoa (Dunkelberg et al, 2012), pelo que a motivação para se tornar um empreendedor é um processo complexo e multifacetado que varia de empreendedor para empreendedor (Kirkwoord \& Walton, 2010).

As teorias sobre a motivação procuram compreender e explorar de que forma a motivação influencia e está na base das opções, da perseverança e do esforço que os indivíduos dedicam em determinadas atividades (Eccles, Wigfield e Schiefele, 1998), pelo que se apresentam de seguida as referidas teorias. 


\subsection{Teorias da motivação aplicadas ao empreendedorismo}

As motivações para o empreendedorismo têm sido investigadas à luz de diferentes teorias, sendo que estas se podem incluir dentro das teorias da motivação de conteúdo ou de processo. As teorias de conteúdo procuram compreender "o porquê" de dado comportamento, isto é, aquilo que move os indivíduos e pretendem identificar os fatores específicos que motivam as pessoas para fazer algo, dando enfâse às causas para dado comportamento (Beardwell et al, 2004); partem da ideia de que as pessoas estão motivadas pelo desejo de satisfazerem as suas necessidades e dão resposta à questão "o que motiva o comportamento?" (Borkowski, 2009). Permitem, por isso, compreender o que leva os indivíduos a criarem o seu próprio negócio. As teorias da motivação de processo focam-se em compreender o "o como", ou seja, o esforço que a pessoa está disposta a dedicar nas atividades (Segal et al, 2005), o processo de desenvolvimento dos motivos (Beardwell et al, 2004) e providenciam uma descrição e uma análise de como o comportamento é iniciado, sustentado e interrompido (Borkowski, 2009). Desta forma, permitem perceber as dificuldades, expectativas e fatores influenciadores envolventes no processo empreendedor.

\subsubsection{Teorias da motivação de conteúdo}

Dentro das teorias da motivação de conteúdo, uma das que recebeu especial atenção - a teoria de McClelland (1961), defende que uma elevada necessidade de autorrealização é um traço comum dos empreendedores (Segal et al, 2005). Ou seja, indivíduos com alto nível de necessidade de autorrealização possuem uma maior propensão para se dedicarem a atividades ou tarefas que envolvam uma maior responsabilidade e que requeiram um esforço individual e, por isso, é provável que essas pessoas prefiram tornar-se empreendedores do que desempenhar outro tipo de papel (Shane et al, 2003). Na sua perspetiva, e considerando que uma pessoa tem uma alta necessidade de reconhecimento, iniciar um novo negócio envolve assumir os riscos, responsabilidades e atenção às finanças da empresa, bem como implica a descoberta de formas inovadoras de desenvolver produtos ou serviços (McClelland, 1961 cit. Marques et al, 2012). 
Outros autores, Gilad e Levine (1986), propuseram uma teoria ainda hoje usada em muitos estudos que permite classificar as motivações em duas categorias: push e pull (Segal et al, 2005; Kirkwood \& Walton, 2010; Marques et al, 2012).

A teoria push defende que os indivíduos são "empurrados" para o processo de empreendedorismo por forças externas negativas como por exemplo, um divórcio, ser ultrapassado por outro colega numa promoção ou insatisfação com o trabalho; os fatores pull são aqueles que "atraem" uma pessoa para iniciar um negócio (Kirkwood \& Walton, 2010), isto é, as pessoas são atraídas para o empreendedorismo pela procura de independência, autorrealização ou pelo reconhecimento de uma oportunidade (Marques et al, 2012).

Na lógica dos fatores $\mathrm{push} / \mathrm{pull}$, alguns autores desenvolveram outros conceitos para categorizar as motivações, como sendo a autonomia (pull) e a necessidade económica (push) (Kirkwood \& Walton, 2010) ou uma outra dicotomia: os conceitos de oportunidade (pull) e de necessidade (push). O empreendedorismo na lógica necessidade versus oportunidade (ou push e pull respetivamente) é largamente influenciado pelo nível de desenvolvimento económico do país no longo prazo e pelo estado da economia no curto prazo (Thurik, Carree, van Stel \& Audretsch, 2008 cit. Hessels, Gelderen \& Thurik, 2008)

Há pessoas que reconhecem uma oportunidade e agem, atraídos pelo sucesso de explorar essa oportunidade e pelo alcance de algum tipo de recompensa, geralmente monetária (Carsrud \& Brannback, 2011). Outros empreendedores são atraídos por orientações de sobrevivência (necessidade), mais preocupados em evitar o falhanço (Carsrud \& Brannback, 2011), iniciam uma start-up por motivos de desemprego ou infelicidade com o emprego atual (Marques et al, 2012).

Os fatores pull são mais prevalentes do que os fatores push (Segal et al, 2005) o que é importante uma vez que os empreendedores que são motivados por este tipo de motivações têm maior probabilidade de ter sucesso nos seus negócios (Amit and Muller, 1995). Tendo em conta o desenvolvimento económico do país, diversos autores defendem que quanto mais desenvolvido for o país maior será a taxa de empreendedores movidos por fatores pull (Kelly et al, 2011; Bosma et al, 2012). Acrescente-se a isto o facto de, nas economias menos desenvolvidas, existir uma menor oferta de postos de trabalho e um 
baixo nível de direitos de segurança social, levando a que as pessoas sintam a necessidade de criar o seu próprio negócio a fim de melhorarem as suas condições de vida (Kelly et al, 2011; Bosma et al, 2012).

Nesta lógica do push e pull, as motivações para o empreendedorismo giram em torno de quatro unidades principais: desejo por independência; motivações monetárias; fatores relacionados com a família; e fatores relacionados com o trabalho (Kirkwood \& Walton, 2010).

O desejo de independência e autonomia é, geralmente, o fator de motivação mais significativo para as pessoas se tornarem empreendedoras, classificado como um fator pull. As motivações monetárias também são categorizadas como um fator pull; nem sempre as pessoas são motivadas pelo dinheiro para iniciarem um empreendimento mas é um fator a ter em conta (Kirkwood \& Walton, 2010).

As motivações relacionadas com o trabalho são geralmente consideradas fatores push e podem manifestar-se de duas formas: insatisfação com o trabalho ou instabilidade no mesmo que podem motivar a pessoa a abandonar o seu emprego e tornarem-se empreendedoras; ou então, o desejo de obter maior flexibilidade ou evolução na carreira, insatisfação com a carreira atual ou dificuldade em encontrar emprego, todos eles podem constituir fatores de motivação para entrar no mundo do empreendedorismo (Kirkwood \& Walton, 2010). Os fatores relacionados com a família, geralmente classificados como push, dizem respeito à difícil combinação entre o emprego e o trabalho doméstico, obrigações familiares ou o desejo por um equilíbrio familiar (Kirkwood \& Walton, 2010).

A distinção entre motivações extrínsecas (associadas a motivações push) e intrínsecas (associadas a motivações pull) também é uma categorização dos conteúdos motivacionais no empreendedorismo. A motivação intrínseca refere-se ao interesse pessoal na tarefa empreendedora; a motivação extrínseca está relacionada com uma recompensa externa que segue determinado comportamento (Carsrud \& Brannback, 2011).

As motivações intrínsecas e extrínsecas não são mutuamente exclusivas já que internamente a pessoa pode estar motivada para atingir determinado objetivo, como por exemplo sucesso pessoal e profissional, e externamente para outro objetivo, como por exemplo, obter status e riqueza (Carsrud \& Brannback, 2011). Se por um lado a maioria da 
pesquisa assume que o empreendedor é motivado por recompensas externas (tais como dinheiro, status e poder) - uma visão mais económica da motivação, por outro lado também é verdade que há pessoas que se envolvem em atividades empreendedoras como um fim em si mesmo - motivação intrínseca (Carsrud \& Brannback, 2011). Da mesma forma, também as motivações push e pull não são mutuamente exclusivas, já que por exemplo, a pessoa pode por um lado, estar desiludida com o trabalho atual e, por outro lado, surgir uma oportunidade noutro contexto.

Ainda nesta lógica push e pull, e segundo um estudo de Carter et al. (2003) as principais motivações dos empreendedores para decidirem se criam ou não um novo negócio estão relacionadas com a inovação, a independência, o reconhecimento, as regras, o sucesso financeiro e a autorrealização, sendo maioritariamente fatores de ordem pull.

Um outro estudo (Rahman \& Rahmanl, 2011) revela um novo conjunto de cinco categorias, umas semelhantes ao estudo acima referido, outras algo diferentes, que ajudam a explicar as motivações para o empreendedorismo: necessidade de realização, necessidade de obter poder, necessidade de afiliação, necessidade de obter segurança e necessidade de obtenção de status.

Também o fator paixão surge na literatura (Shane et al, 2003) e está relacionado com uma paixão "egoística" pelo trabalho e por servir a sociedade e a sua empresa sem interesses por trás. São pessoas que gostam daquilo que fazem e que têm prazer em construir algo de novo e torná-lo lucrativo. Embora ainda não existam muitos estudos sobre o papel da paixão no empreendedorismo, foi mostrado que a paixão tem um efeito direto no crescimento da empresa (Baum, Locke \& Smith, 2001 cit. Shane et al, 2003).

A tabela $\left(\mathrm{n}^{\circ} 2\right)$ permite sistematizar as diversas motivações empreendedoras que foram surgindo na literatura.

\begin{tabular}{|c|c|c|}
\hline \multicolumn{3}{|c|}{ Categorias das motivações empreendedoras } \\
\hline Categorias & Descrição & Autores \\
\hline $\begin{array}{c}\text { Inovação/criação } \\
(p u l l)\end{array}$ & $\begin{array}{c}\text { Intenção da pessoa de atingir algo } \\
\text { novo; desenvolver um novo }\end{array}$ & $\begin{array}{c}\text { Carter et al, 2003; Giacomin et } \\
\text { al, 2011; Edelman et al, 2010; } \\
\text { produto/serviço; continuar a }\end{array}$ \\
& Miller et al, 2012; \\
\hline
\end{tabular}




\begin{tabular}{|c|c|c|}
\hline & aprender; desenvolvimento pessoal & \\
\hline $\begin{array}{l}\text { Independência } \\
\text { (pull) }\end{array}$ & $\begin{array}{l}\text { Desejo de liberdade, controlo e } \\
\text { flexibilidade na gestão do tempo e } \\
\text { do trabalho; }\end{array}$ & $\begin{array}{l}\text { Carter et al, 2003; Giacomin et } \\
\text { al, 2011; Hessels et al, 2008; } \\
\text { Edelman et al, 2010; Shane et al, } \\
\text { 2003; Kolvereid, 1996 cit. Miller } \\
\text { et al, 2012; }\end{array}$ \\
\hline $\begin{array}{c}\text { Reconhecimento/ } \\
\text { Status } \\
\text { (extrínseca) }\end{array}$ & $\begin{array}{l}\text { Obtenção de status, aprovação e } \\
\text { reconhecimento por parte dos } \\
\text { outros; ser respeitado pela família, } \\
\text { amigos e comunidade; ter acesso a } \\
\text { determinados recursos (carro, casa, } \\
\text { estudos); }\end{array}$ & $\begin{array}{l}\text { Carter et al, 2003; Rahman \& } \\
\text { Rahmanl, 2011; Giacomin et al, } \\
\text { 2011; Edelman et al, 2010; } \\
\text { Miller et al, 2012; }\end{array}$ \\
\hline $\begin{array}{l}\text { Roles (Modelo, } \\
\text { papéis) }\end{array}$ & $\begin{array}{l}\text { Desejo do indivíduo de seguir } \\
\text { tradições familiares ou o exemplo } \\
\text { de outros significativos; }\end{array}$ & Carter et al, 2003. \\
\hline $\begin{array}{l}\text { Sucesso } \\
\text { financeiro }(p u l l)\end{array}$ & $\begin{array}{l}\text { Intenção de ganhar mais dinheiro; } \\
\text { alcançar segurança financeira }\end{array}$ & $\begin{array}{l}\text { Carter et al, 2003; Hessels et al, } \\
\text { 2008; Edelman et al, } 2010\end{array}$ \\
\hline $\begin{array}{l}\text { Autorrealização } \\
(p u l l)\end{array}$ & $\begin{array}{l}\text { Perseguição de objetivos pessoais; } \\
\text { liderar e motivar os outros; desafio } \\
\text { pessoal; resolver um problema } \\
\text { complexo }\end{array}$ & $\begin{array}{l}\text { Carter et al, 2003.; Rahman \& } \\
\text { Rahmanl, 2011; (Birley and } \\
\text { Westhead, 1994; Edelman et al, } \\
\text { 2010); Miller et al, 2012; }\end{array}$ \\
\hline $\begin{array}{l}\text { Necessidade de } \\
\text { segurança }\end{array}$ & $\begin{array}{l}\text { Ter um emprego seguro; ter } \\
\text { proteção contra perda de } \\
\text { rendimentos ou doença; }\end{array}$ & $\begin{array}{l}\text { Kolvereid, } 1996 \text { cit. Miller et al, } \\
\text { 2012; Rahman \& Rahmanl, } 2011\end{array}$ \\
\hline $\begin{array}{l}\text { Insatisfação } \\
\text { profissional } \\
\text { (push) }\end{array}$ & $\begin{array}{l}\text { Insatisfação com a ocupação } \\
\text { profissional; dificuldade em } \\
\text { encontrar o emprego certo; }\end{array}$ & Giacomin et al, 2011; \\
\hline $\begin{array}{c}\text { Paixão } \\
\text { (intrínseco) }\end{array}$ & $\begin{array}{l}\text { Paixão pelo trabalho; servir os } \\
\text { colaboradores e a sociedade } \\
\text { desinteressadamente; gosto pela } \\
\text { criação de uma organização }\end{array}$ & $\begin{array}{l}\text { Shane et al, 2003; Miller et al, } \\
\text { 2012; }\end{array}$ \\
\hline
\end{tabular}

Tabela 2 - Categorias de motivações no empreendedorismo

Fonte: Elaboração própria

\subsubsection{Teorias da motivação de processo}

As teorias da motivação de processo focam-se mais nas atitudes e crenças e como elas podem prever o comportamento e as intenções das pessoas (Segal et al, 2005). Deste 
ponto de vista, os empreendimentos dos indivíduos são o resultado de processos cognitivos. As pessoas são capazes de pensar em objetivos e resultados futuros, de decidir quais deles são os mais desejados e se é viável perseguir o alcance desses objetivos. Não é razoável esperar que as pessoas vão perseguir objetivos que considerem ser indesejáveis ou inviáveis (Segal et al, 2005).

Estas ideias tiveram início com a Teoria das Expectativas de Vroom (1964) que defende que um indivíduo irá adotar, entre os vários comportamentos, aquele que o levará ao alcance do resultado desejado, ou seja, uma ação é levada a cabo quando o indivíduo acredita que o seu esforço conduzirá a uma performance de sucesso, a qual lhe trará determinados resultados com valores positivos ou negativos (Olsen, Roese e Zanna 1996; Vroom 1964 cit. Edelman et al, 2010).

Baseadas no trabalho de Vroom, surgiram posteriormente outras duas teorias, as quais ainda hoje são mobilizadas em estudos sobre as motivações empreendedoras: a teoria da definição de objetivos de Locke (1968) e a teoria da autoeficácia de Bandura (1977) (Segal et al, 2005).

Segundo Locke (1991 cit. Hechavarria et al, 2012) aquilo que as pessoas fazem é em grande parte influenciado pelos seus objetivos e pela confiança percebida em ser capaz de efetuar essas ações. Os objetivos são representações mentais do que o futuro poderia ser, permitindo aos empreendedores não desistirem (Perwin, 2003 cit. Carsrud \& Brannback, 2011). A sua teoria da definição de objetivos sugere que o planeamento do negócio antes da partida para a ação permitirá obter melhores resultados, porque ter um plano facilita o alcance dos mesmos (Hechavarria et al, 2012). Contudo, por si só, esses objetivos não são suficientes para levar à criação da empresa, pois é necessário que o indivíduo acredite que é capaz de o fazer. Daí surge a teoria da autoeficácia de Bandura.

Autoeficácia é a crença da pessoa nas suas capacidades para reunir e aplicar os recursos, ferramentas e competências pessoais necessários para atingir um certo nível de realização em certa tarefa (Krueger \& Brazeal, 1994; Bandura, 1997 cit. Shane et al, 2003), ou seja, a autoeficácia serve de moderador entre os objetivos e a performance (Hechavarria et al, 2012). A autoeficácia é então um antecedente chave das intenções para o empreendedorismo (Carsrud \& Brannback, 2011) e um fator chave na explicação pela 
opção e persistência no comportamento empreendedor (Rubio et al, s/d). Quanto maior for a autoeficácia percebida pela pessoa, maior será o seu esforço e perseverança na resolução de dado problema e mais facilmente atribuirá as falhas a si própria em vez de associar a fatores externos (Hechavarria et al, 2012). Indivíduos com alto grau de autoeficácia têm maior propensão para o empreendedorismo e acreditam que possuem uma ideia viável para o negócio e que ela é concretizável (Wilson et al, 2007). Pelo contrário, indivíduos com baixo nível de autoeficácia não acreditam poder ter sucesso e, por isso, aplicarão menos esforço (Hechavarria et al, 2012).

No seguimento destas teorias, surgiu ainda um outro modelo, também muito relevante, o modelo da expectativa-valor. Esta teoria "liga o alcance da performance, a persistência e a escolha mais diretamente aos indivíduos" (Eccles \& Wigfield, 2002, p.118). Na sua investigação Eccles e os seus colegas argumentam que as expetativas para o sucesso e a capacidade do indivíduo para avaliar a sua competência (autoeficácia) influenciam os resultados da atividade; ademais, revelou também que o valor que é depositado nessa mesma atividade, ou seja, as razões que o indivíduo tem para executar determinada atividade, influenciam de forma considerável a persistência na ação (Eccles \& Wigfield, 2002). No seu modelo, defendem que as escolhas do indivíduo são influenciadas por características positivas e negativas da tarefa e as escolhas têm custos associados precisamente porque uma escolha elimina, geralmente, outras opções. Assim, o valor relativo e probabilidade de sucesso das várias opções são aspetos determinantes da escolha. Por isso, o envolvimento em determinadas atividades e a avaliação do sucesso dependerá dos motivos e valores que as pessoas atribuem a essas mesmas atividades. As expetativas que o indivíduo possui sobre o sucesso, as crenças sobre a capacidade para ser bemsucedido $\mathrm{e}$ as motivações que o leva a querer ser empreendedor definem o seu comportamento (Eccles \& Wigfield, 2002). Por sua vez, estas variáveis de autoeficácia e crenças do individuo são influenciadas pela sua comunidade e pela sua experiência anterior. Isto é, e tendo também surgido como um outro fator de motivação na literatura, e que parece ter uma grande preponderância no empreendedor para a criação de um novo negócio é a influência de outros significativos, isto é, "role models". De facto, aqueles que possuem familiares, amigos ou pessoas próximas que tenham ingressado nesta aventura, é mais 
provável que também o façam (Williams \& Williams, 2012). Isto pode explicar o porquê de alguns países terem níveis de empreendedorismo muito superiores a outros. As pessoas influenciam-se umas às outras, levando à criação de mais iniciativas empreendedoras e cultivando assim uma cultura empreendedora.

Em suma, o valor que o empreendedor atribui à sua atividade terá uma influência na sua motivação e na persistência que possui sobre essa mesma atividade (Eccles \& Wigfield, 2002).

A junção destas teorias providencia desta forma um modelo individual de motivação que nos permite compreender o processo de criação de um negócio (Hechavarria et al, 2012). Estes modelos estão implícita ou explicitamente fundamentados na conceção básica de que as intenções de um indivíduo para se tornar um empreendedor são previstas pela resposta a duas questões: (1) o empreendedorismo é desejável para mim? (isto é, leva-me a alcançar os resultados e objetivos que eu desejo?) e (2) o empreendedorismo é viável para $\mathrm{mim}$ ? (isto é, tenho aquilo que preciso para ter sucesso enquanto empreendedor?) (Segal et al, 2005). De facto, alguns investigadores descobriram que os empreendedores que acreditam nas suas capacidades e habilidades são motivados para exercer o esforço necessário na criação da sua nova aventura (Edelman et al, 2010).

Em suma, isto permite-nos então perceber que os empreendedores estão dispostos a despender esforço na criação do seu próprio negócio porque isso lhes levará a alcançar os seus desejos, isto é, os resultados desejados (Edelman et al, 2010).

Para concluir, importa salientar que as motivações da pessoa podem influenciar a transição dos indivíduos empreendedores de uma fase do processo ${ }^{2}$ para outra (Shane et al, 2003). Pouca investigação na área do empreendedorismo considerou os efeitos da motivação nas diversas fases do processo empreendedor (Shane et al, 2003). Isto é uma limitação existente uma vez que o processo de criação de uma empresa é dinâmico e é provável que envolva diferentes motivações nas suas diversas fases. Por exemplo, um engenheiro pode estar motivado para a criação de um novo equipamento médico mas pode

\footnotetext{
${ }^{2}$ Por exemplo, a transição do reconhecimento de uma oportunidade para o desenvolvimento efetivo da ideia.
} 
faltar-lhe motivação para procurar os recursos financeiros necessários para o fazer (Hechavarria et al, 2012). As motivações serão então o mote para se perceber se o indivíduo se mantém ou não neste processo, aplicando todo o seu esforço ou não (Shane et al, 2003).

\section{Capítulo 3- O Empreendedorismo Social}

\subsection{A noção de Empreendedorismo Social}

"Social entrepreneurs are not content just to give a fish, or teach how to fish. They will not rest until they have revolutionized the fishing industry.'

Bill Drayton, Founder and CEO of Ashoka ${ }^{3}$

O empreendedorismo social é um campo de ação e investigação que tem vindo a ganhar uma crescente atenção por parte de académicos, políticos e profissionais dos diversos setores da economia. E, embora a linguagem do empreendedorismo social possa ser relativamente recente, o fenómeno em si não o é (Instituto de Empreendedorismo Social, 2013). Ele possui já uma longa tradição que data dos séculos XVIII e XIX, quando filantrópicos e detentores de negócios como Robert Owen demonstraram alguma preocupação com o bem-estar dos seus empregados ao melhorarem as suas vidas ao nível do trabalho, educação e cultura (Shaw \& Carter, 2007).

Importa recordar a noção de empreendedorismo social que nos é dada pelos autores Certo e Miller (2008) já citada no início desta dissertação, como sendo um processo que envolve o reconhecimento, avaliação e exploração de oportunidades que resultam em valor social como a satisfação de necessidades básicas, por oposto à criação de riqueza pessoal ou dos acionistas. Casos bem conhecidos de empreendedores sociais são: Muhammad

\footnotetext{
${ }^{3}$ www.ashoka.org. Fundada em 1981, é uma das maiores associações no mundo de líderes empreendedores sociais (Moore, 2009). O seu staff trabalha no sentido de identificar empreendedores sociais emergentes por todo o mundo e procura investir e apoiar o seu trabalho (Ashoka About Us, 2012 cit. Moore, 2009).
} 
Yunus ${ }^{4}$, que em 1976 criou o Grammen Bank para erradicar a pobreza e dar empowerment às mulheres no Bangladesh (Mair \& Martí, 2006) ou Maria Montessori, a primeira médica italiana, que nos anos de 1960 começou a trabalhar com crianças e criou um método de educação revolucionário que defendia que cada criança tinha um desenvolvimento único (Instituto de Empreendedorismo Social, 2013).

Hoje em dia, o mundo enfrenta um enorme conjunto de problemas e não precisamos de pensar muito para enumerar alguns como a pobreza, a fome, o aquecimento global, as pandemias, o terrorismo e muitos outros. O empreendedorismo social é cada vez mais reconhecido como a solução para esses mesmos problemas sociais (Sud et al, 2009). Na verdade, o empreendedorismo social tem maior probabilidade de ocorrer em contextos onde existam problemas socioeconómicos, ambientais e culturais significativos e aumenta ainda mais se existirem menos instituições que colmatem essas falhas (Dacin et al, 2010). No entanto, pode ocorrer em diversos contextos e pode envolver empreendedores individuais, organizações novas ou já existentes ${ }^{5}$ ou governos (Certo \& Miller, 2008).

Importa realçar que o empreendedorismo social é muito mais do que filantropia ou caridade na medida em que promove uma solução duradoura, atraente e sustentável para os problemas sociais (Nga \& Shamuganathan, 2010). De facto, os empreendedores sociais promovem a sua missão e a mudança social providenciando aos seus beneficiários suporte para realizarem e porem em prática o seu potencial de forma a que tenham responsabilidade sobre a melhoria da sua própria qualidade de vida (Nga \& Shamuganathan, 2010), fomentando assim o empowerment nas pessoas e permitindo maior autonomia e aprendizagem ao longo da vida, de forma sustentada.

O empreendedorismo social tem estado muito associado às instituições de caridade, igrejas, setor não-lucrativo e organizações de voluntariado. O designado terceiro setor tem

\footnotetext{
${ }^{4}$ Muhammad Yunus recebeu em 2006 o Prémio Nobel da Paz graças à criação do Grammen Bank, com o qual conseguiu ajudar os seus clientes a ultrapassar um problema de pobreza através do microcrédito. $\mathrm{O}$ microcrédito já existiu de várias formas ao longo dos séculos mas Yunus foi o primeiro a desafiar a sua teoria mostrando como este podia ser usado como uma estratégia para minorar a pobreza ao conceder empréstimos grátis às pessoas das vilas mais pobres (Moore, 2009).

${ }^{5} \mathrm{O}$ processo de empreendedorismo social pode ocorrer de igual forma numa nova organização ou numa já existente e se for este o caso, pode também ser denominado de "Social intrapreneurship" (Mair \& Martí, 2006).
} 
vindo a expandir-se em diversas áreas, quer a nível de respostas sociais para os problemas da sociedade, quer na criação de mais empregos, crescimento da economia e pelo preenchimento das lacunas às quais o Estado não consegue dar resposta, pois se é verdade que os serviços públicos tentam alcançar os mais pobres, também é verdade que estas respostas são maioritariamente ineficientes (Seelos \& Mair, 2005; Shaw \& Carter, 2007).

Contrariamente ao que muitas das vezes é pensado, organizações não lucrativas ${ }^{6}$ que empreguem boas práticas financeiras podem ter um grande crescimento e pagar salários muito competitivos (Whitman, 2011), mas isso, infelizmente, não é uma realidade nas organizações não lucrativas em Portugal, o que faz com que, por exemplo, seja mais difícil captar recursos humanos. A verdade é que ter pessoas qualificadas com conhecimento e ferramentas nestes domínios, pode potenciar a mobilização de práticas de gestão que possibilitem alcançar maior sustentabilidade sendo por isso essencial reter estes experts (Whitman, 2011). Recentemente têm surgido diversos tipos de apoios para o lançamento e sustentabilidade dos projetos sociais; é o caso de algumas organizações que surgiram com o objetivo primário de apoiar empreendedores sociais, como a Ashoka, o Instituto de Empreendedorismo Social e até diversos concursos de empreendedorismo social que estabelecem prémios monetários e apoio técnico (recursos humanos, incubadoras, formação, etc.) que permitem assim o crescimento deste tipo de projetos.

Em suma, o empreendedorismo social constitui atividade com objetivos comunitários, gerando lucro para reinvestimento na própria organização (Harding, 2006 cit. Steinerowski et al, 2008).

Em anos mais recentes, surgiu uma nova forma de organização, as empresas sociais, onde o empreendedorismo social pode ter também um grande destaque. De forma simples, as empresas sociais são "organizações que procuram soluções de negócio para problemas sociais e podem incluir cooperativas, empresas comunitárias, organizações empresariais de voluntários e outras formas de negócios sociais" (Hall, Miller \& Millar, 2012, p.50).

\footnotetext{
${ }^{6}$ Os lucros são públicos e não podem ser distribuídos por entidades privadas, quer sejam indivíduos ou outras corporações (Whitman, 2011).
} 
Um exemplo de uma empresa social é a Grameen Danone, criada em 2005, a partir de uma parceria entre o banco Grameen e a empresa de lacticínios Danone, e cujo objetivo é reduzir os níveis de subnutrição das crianças do Bangladeche. Esta empresa produz um iogurte para crianças e vende-o a um preço acessível para os mais desfavorecidos; a este iogurte são adicionados todos os nutrientes necessários para crescer e de que estas crianças carecem. É uma empresa sustentável e que defende que os proprietários não deverão retirar quaisquer dividendos para além do montante original investido. O sucesso desta empresa não é medido pelo lucro mas sim pelo número de crianças que fogem à subnutrição nesse ano (Yunus, 2010). De facto, "Numa empresa social, o investidor tem o objetivo de ajudar as outras pessoas sem obter qualquer contrapartida financeira para si próprio. A empresa social é uma empresa porque deve ser autossustentável - ou seja, deve produzir um rendimento suficiente para cobrir os seus próprios custos. Parte do superavit que a empresa social cria é investida na expansão da empresa e uma outra parte fica de reserva para cobrir imprevistos" (Yunus, 2010, p.19).

Fazendo uma analogia com as organizações sem fins lucrativos, tradicionalmente estas organizações são fundadas com base em doações, fundos do governo, taxas de utilização e empréstimos (DiMaggio and Anheier, 1990 cit. Sud et al, 2009). As empresas sociais, contudo, têm procurado outro tipo de modelo de financiamento através de movimentos estratégicos para novos mercados de forma a subsidiar as suas atividades quer através da exploração de oportunidades lucrativas no seio das atividades das suas subsidiárias lucrativas ou via alianças e parcerias com empresas comerciais (Nicholls, 2004 cit. Sud et al, 2009). São, por isso, baseadas em princípios inovadores e sustentáveis, por oposto à lógica tradicional que as instituições procuram, e desta forma evitam a dependência financeira do Estado (Parente et al, 2012) e, daí, merecem um destaque especial neste momento. Ademais, e ao contrário das organizações sem fins lucrativos, uma empresa social tem investidores e proprietários, no entanto, eles não recebem lucros, dividendos ou qualquer outro tipo de benefício financeiro (Yunus, 2010). As empresas sociais têm de ser distinguidas de outro tipo de organizações e iniciativas que possuem benefícios sociais para as suas comunidades mas que não são "negócios" (Thompson \& Doherty, 2006). 
Parece claro afirmar que, se por um lado, a missão de um empreendedor social é de certeza, social, a sua organização ou projeto só será sustentável através das receitas que gera; daí que, as preocupações financeiras devam ser equilibradas com as sociais (Dacin et al, 2010). Assim, o empreendedorismo social tem uma preocupação acrescida àquela que todos os negócios possuem: como equilibrar as preocupações económicas e sociais na gestão da organização de forma a garantir a satisfação mútua dos vários stakeholders, o que umas vezes poderá ser visto como uma oportunidade mas também terá os seus constrangimentos (Dacin et al, 2010).

Este conceito de empresa social é muito interessante e já começa a surgir em Portugal, contudo o empreendedorismo social ocorre também noutro tipo de organizações já que os empreendedores sociais poderão albergar os seus projetos, por exemplo, em Organizações Não Governamentais (ONG) ou atividades com fins lucrativos (Yunus, 2010); contudo, seja que iniciativa for, deverá ter como primeiro objetivo um propósito social.

Importa ainda distinguir este conceito do de responsabilidade social empresarial, pois este último "designa frequentemente um fundo de beneficência reservado por uma empresa com fins lucrativos para o bem da comunidade local" (Yunus, 2010, p. 37), mas o seu objetivo primário é obtenção de lucro e não as questões sociais.

Para concluir, e tendo em conta que o empreendedorismo social é o resultado de traços especiais pessoais, que vão além de motivações altruísticas e refletem a determinação para mudar toda a sociedade partilhados apenas por uma pequena percentagem da população (Drayton, 2002 cit. Seelos et al, 2005), importa então explorar mais aprofundadamente o que caracteriza o empreendedor social.

\subsection{Empreendedor Social}

"Social innovator or social entrepreneur, a champion of systemic change, creating transformative forces with his idea to find new and appropriate solutions to existing problems" (Sen, 2007, p.535). 
Os poucos estudos existentes na área do empreendedorismo social procuraram essencialmente perceber quem são os empreendedores sociais, isto é, identificar e definir os seus traços de personalidade. De acordo com alguns desses estudos, os empreendedores sociais são caracterizados por traços especiais (Drayton, 2002 cit. Mair \& Noboa, 2005), ferramentas de liderança (Henton, Melville \& Walesh, 1997 cit. Mair \& Noboa, 2005), uma paixão enorme pelo trabalho pelo qual lutam para realizar a sua visão (Bornstein, 1998; Boschee, 1995, cit. Mair \& Noboa, 2005), um forte sentido ético (Bornstein, 1998 cit. Mair \& Noboa, 2005) e determinadas qualidades empreendedoras (Drayton, 2002 cit. Mair \& Noboa, 2005).

Os empreendedores sociais são pessoas que identificam uma falha na sociedade e a transformam numa oportunidade introduzindo imaginação e visão na sua solução; são indivíduos que recrutam e motivam outros para a sua causa e constroem redes de pessoas essenciais ao mesmo tempo que asseguram os recursos necessários; além disso, ultrapassam os obstáculos e os desafios e introduzem sistemas próprios de gestão do seu negócio social (Thompson, 2002).

Numa descrição ideal, é possível enumerar alguns pontos-chave que procuram definir o que é um empreendedor social. Eles são na verdade agentes de mudança no setor social, na medida em que adotam uma missão que crie e sustente valor social; reconhecendo e rentabilizando novas oportunidades que vão de encontro à sua missão; procurando constantemente a inovação, adaptação e aprendizagem; exibindo responsabilidade acrescida perante as pessoas e os resultados criados (Dees, 1998). Os empreendedores sociais atacam diretamente a causa dos problemas em vez de tentar apenas tratar os sintomas e, embora possam atuar apenas localmente, as suas ações têm um impacto global em diferentes áreas de atuação, quer educação, saúde, ambiente, cultura, artes e outros (Dees, 1998).

Para um empreendedor social a sua missão é fundamental, procura realmente uma mudança no mundo e, por isso, não pode ser reduzida à criação de lucro para a pessoa. Obter lucro e criar riqueza podem fazer parte do modelo mas são apenas meios e não um 
fim em si mesmo (Dees, 1998). Por isso, criam ou aplicam modelos económicos viáveis para atingir propósitos sociais ou ambientais (Whitman, 2011).

Destacam-se também a sua habilidade para encarar e potenciar a transformação social eficientemente, num contexto com diversos riscos (Thompson, 2002 cit. Nga \& Shamuganathan, 2010). Ademais, os empreendedores sociais possuem um alto grau de comprometimento com a sua visão social e são apreciadores de práticas sustentáveis (Nga \& Shamuganathan, 2010). Uma das grandes ferramentas que possuem é a sua capacidade de inspirar, atrair e mobilizar esforços de parceiros comerciais e não comerciais, donativos, voluntários e colaboradores na criação de riqueza social (Zahra et al, 2009).

A tabela 3 sumariza as diferentes características que foram surgindo na literatura.

\begin{tabular}{|l|l|}
\hline \multicolumn{1}{|c|}{$\begin{array}{c}\text { Características dos } \\
\text { empreendedores sociais }\end{array}$} & \multicolumn{1}{|c|}{ Autores } \\
\hline Inovadores & $\begin{array}{l}\text { Dees, 1998; Sud et al, 2009; Steinerowski et al, 2008; } \\
\text { Nga \& Shamuganathan, 2010; Shaw \& Carter, 2007 }\end{array}$ \\
\hline Persistentes & Dees, 1998; Steinerowski et al, 2008; Moore, 2009; \\
\hline $\begin{array}{l}\text { Apaixonados pela sua visão e } \\
\text { missão }\end{array}$ & $\begin{array}{l}\text { Steinerowski et al, 2008; Cardon et al, 2009 cit. Dacin et } \\
\text { al, 2010; Bornstein, 1998 cit. Mair \& Martí, 2006; Hall et } \\
\text { al, 2012; }\end{array}$ \\
\hline Pró-ativos & Steinerowski et al, 2008; \\
\hline Propensos ao risco & Steinerowski et al, 2008; \\
\hline Capacidade de liderança & $\begin{array}{l}\text { Thompson, Alvy \& Lees, 2000 cit. Mair \& Martí, 2006; } \\
\text { Moore, 2009; }\end{array}$ \\
\hline Forte sentido ético & Drayton, 2002 cit. Mair \& Martí, 2006; Hall et al, 2012; \\
\hline Altruístas & Hall et al, 2012; \\
\hline Criativos & Shaw \& Carter, 2007; \\
\hline Visionários & Moore, 2009; \\
\hline
\end{tabular}


Tabela 3- Características dos empreendedores sociais

Fonte: Elaboração própria

\subsection{Empreendedorismo versus Empreendedorismo Social}

$\mathrm{O}$ que distingue, afinal de contas, o empreendedorismo tradicional e o empreendedorismo social? Para podermos compreender o segundo fenómeno, foi crucial estudarmos o primeiro uma vez que, como já foi referido, o empreendedorismo social é um subtipo de empreendedorismo. Como é óbvio, eles possuem diferenças entre eles, mas também algumas semelhanças, as quais importa agora salientar.

Por um lado, há quem defenda que os empreendedores sociais possuem muitas similaridades com os empreendedores convencionais. Drucker (1999) e Leadbeater (1997) defendem que muitos dos traços e comportamentos dos empreendedores sociais são o espelho dos empreendedores comerciais, incluindo as duas determinações, ambições, carisma, liderança, habilidade de comunicar a sua visão e inspirar os outros e a maximização na utilização dos recursos.

Determinadas variáveis foram já analisadas por diversos autores, no sentido de compreender as diferenças entre os dois tipos de empreendedorismo. Em boa medida, a diferença chave é que no empreendedorismo comercial o foco principal é no retorno económico enquanto que no empreendedorismo social é no retorno social. Ou seja, os empreendedores convencionais procuram essencialmente o lucro (Kirzner, 1973), pelo que a sua performance está agarrada ao retorno financeiro (Austin et al, 2006). Por sua vez, os empreendedores sociais procuram, geralmente, quer atingir metas económicas, quer sociais (Dorado, 2006). Assim, as empresas sociais partilham com as empresas comerciais a procura da geração de receitas mas as primeiras procuram também alcançar objetivos sociais (Di Domenico et al, 2010 cit. Rubio et al, s/d).

As competências necessárias para iniciar um negócio e mantê-lo são semelhantes para os empreendedores comerciais e sociais: ambos têm de conhecer a indústria onde operam, os seus fornecedores, clientes e concorrência e o talento que é necessário trazerem para a sua empresa. 
Importante é também a sua rede de contactos, embora de forma diferente: para os empreendedores sociais manter estas relações é absolutamente crucial. O escasso acesso a recursos com que eles se deparam faz da sua capacidade de relacionamento e criação de reputação para com investidores e contribuidores, uma das competências mais importantes de se ter (Austin et al, 2006). Uma vez que os empreendedores sociais dependem, muitas das vezes, de doações de fundações, contribuições individuais, quotas, taxas de utilização e pagamentos do governo, a confiança deve ser acrescida já que todas estas pessoas possuem expectativas e motivações face à organização que devem ser cumpridas (Austin et al, 2006). Daqui também surge a importância de, por um lado, estabelecerem parcerias e alianças de modo a aumentar o seu impacto e a transmitir aos outros os seus métodos de criação de valor (Meykens et al, 2010 cit. Rubio et al, s/d) e, por outro lado, envolverem os seus stakeholders na criação e gestão das suas empresas (Di Domenico et al, 2010 cit. Rubio et al, s/d).

No que diz respeito aos recursos humanos, tanto as empresas comerciais como as sociais, devem procurar reter talentos e, por isso, saber motivar os seus gestores, colaboradores, fundadores e outras pessoas essenciais para a organização (Austin et al, 2006). Para tal, e assim como os empreendedores comerciais, os empreendedores sociais deverão ter uma forte reputação que transmita confiança aos outros e ainda uma grande vontade de investir na empresa e na sua missão (Austin et al, 2006).

Ademais, o empreendedorismo tradicional tende a focar-se no progresso e na satisfação de novas necessidades do mercado enquanto que o empreendedorismo social se foca geralmente nas necessidades que já existem há algum tempo e, por vezes, mais básicas do mercado através de abordagens inovadoras (Austin et al, 2006). Há quem defenda que as organizações com fins sociais emergem quando existem falhas no mercado, ou seja, as forças comerciais, como sendo os serviços públicos ou as empresas por exemplo, não conseguem dar resposta a uma necessidade social (Weisbrod, 1977 cit. Austin et al, 2006). Para um empreendedor comercial a oportunidade que ele persegue deverá ter um potencial de mercado elevado ou uma previsão de grande crescimento e a indústria tem de ser atrativa pois é essa procura que influencia a criação de valor (Dees, 1998). Pelo contrário, para o empreendedor social uma necessidade identificada ou uma falha no mercado 
garantem, por norma, um tamanho de mercado suficiente (Dees, 1998). Isto permite, por um lado, a abrangência de um maior número de oportunidades já que, para o empreendedor social, é perfeitamente possível projetar um empreendimento autossustentável ou um que requeira subsídios, ao passo que, para o empreendedor comercial, oportunidades que não sejam lucrativas e representem altos níveis de crescimento não são tão atrativas (Dees, 1998).

No que respeita à mobilização de recursos, esta é diferente uma vez que o acesso aos mesmos no empreendedorismo social é mais difícil e o retorno financeiro dos negócios sociais torna geralmente difícil a compensação dos recursos humanos e a competitividade para com os mercados comerciais. Os empreendedores sociais parecem não mobilizar de forma tão competitiva os seus recursos mas, pelo contrário, tendem a usá-los de forma criativa e a partilhá-los com outras organizações (Dacin et al, 2010).

Um outro desafio para os empreendedores sociais é a medição da performance, ao contrário do que acontece com os empreendedores comerciais que facilmente conseguem adquirir medidas tangíveis e quantificáveis, tais como os indicadores financeiros. $\mathrm{O}$ desafio na medição da performance da mudança social é enorme por não ser quantificável, por ser multicausal, ter uma dimensão temporal longa e diferentes perceções para as pessoas do impacto causado (Austin et al, 2006). As medidas de performance no empreendedorismo social são menos estandardizadas e mais adaptadas a cada organização e, embora já existam algumas métricas que permitem quantificar o ganho social (Young, 2006 cit. Certo \& Miller, 2008), a verdade é que este é um trabalho que tem de ser mais desenvolvido. O impacto e a performance são muito difíceis de medir no setor social e mesmo que possam existir métodos para medir a performance, o verdadeiro impacto social demora muito tempo a sentir-se (Austin et al, 2006).

Alguns autores argumentam que os empreendedores sociais possuem uma tarefa mais complexa e trabalham num ambiente também ele mais complexo que os empreendedores comerciais. Os primeiros têm não apenas de obter sucesso para o seu negócio como também produzir resultados sociais que tenham impacto e, por isso, têm de ter ferramentas do empreendedorismo comercial combinadas com uma abordagem ética e social que os permitam desenvolver o seu trabalho (Steinerowski et al, 2008). 
Os valores éticos que guiam o empreendedorismo social ajudam a assegurar que o dinheiro público é bem aplicado, as ideias não são corrompidas por outros interesses e que as pessoas estão totalmente comprometidas com o trabalho da organização (Shaw \& Carter, 2007). Isto não significa que os empreendedores comerciais não tenham também os seus valores éticos.

Por último, uma diferença também apontada por outros autores é a forma de organização da empresa ("for-profit" ou "nonprofit"), geralmente definida pelos sistemas legais dos países onde os empreendedores estão. $\mathrm{Na}$ maioria dos casos, os empreendimentos sociais são levados a cabo em organizações sem fins lucrativos (Shaw \& Carter, 2007). Contudo, os autores Mair \& Martí (2006) consideram que o empreendedorismo social pode acontecer numa base de geração de lucro ${ }^{7}$. A análise feita pelos mesmos autores a diversos casos de estudo de iniciativas for-profit ou not-for-profit revela que a escolha sobre este critério é ditada pela natureza das necessidades sociais, dos recursos necessários, do capital e da capacidade de gerar valor económico, ou seja, está dependente do modelo de negócio e das necessidades sociais a serem resolvidas.

Assim, mais do que pensar neste critério lucrativo ou não lucrativo, a grande diferença entre o empreendedorismo comercial e o social reside na prioridade dada à criação de riqueza social versus a criação de riqueza económica (Mair \& Martí, 2006). Contudo, a criação de riqueza económica é importante para o empreendedor social poder garantir a sustentabilidade da sua organização e para que esta se torne autossustentável. Ainda assim, aqueles empreendedores sociais que dão resposta a necessidades básicas como alimentação, saúde, água, educação, enfrentam um grande desafio: a dificuldade de capturar valor económico, uma vez que, na maioria das vezes, os beneficiários não estão capazes de pagar pelos produtos/serviços que lhes são providenciados (Seelos \& Martí, 2005 cit. Mair \& Martí, 2006). Em suma, “enquanto um empreendedor comercial procura oportunidades de criar e capturar valor económico, para um empreendedor social, o foco é

\footnotetext{
7 Por exemplo, o caso do Grameen Bank no Bangladesh o qual usa os lucros gerados nas suas diversas atividades para investir em novos projetos sociais; para este banco, criar valor económico é crítico para assegurar a continuidade da sua missão, nomeadamente providenciar empréstimos às pessoas mais pobres do país, para que elas possam iniciar a sua própria empresa e gerar novos postos de trabalho (Mair \& Martí, 2006).
} 
o problema da sociedade a resolver, mesmo que a resolução desse problema não pareça permitir fazer lucros. O empreendedor social procura maximizar a criação de valor social para a sociedade, satisfazendo a captura de valor (para si e para a sua organização) a um nível que assegure a sustentabilidade da solução a longo prazo" (Instituto de Empreendedorismo Social, 2013).

Para concluir, é importante reforçar que toda esta distinção não é dicotómica mas que ambos os tipos de empreendedorismo se podem inserir num contínuo desde o puramente social ao puramente económico e que, mesmo nestes extremos, existem pontos em comum entre eles. Assim o é, uma vez que a atividade social reflete realidades económicas (para sustento da organização) e a atividade económica gera de alguma forma valor social (Austin et al, 2006), por exemplo na criação de emprego.

A tabela 4 apresenta uma síntese das principais distinções apontadas aos dois tipos de empreendedorismo em questão.

\begin{tabular}{|c|c|c|}
\hline & Empreendedorismo Comercial & Empreendedorismo Social \\
\hline Definição & $\begin{array}{l}\text { Um indivíduo que persegue uma } \\
\text { visão baseada numa nova ideia } \\
\text { com o objetivo de criar } \\
\text { inovações de sucesso } \\
\text { (Schumpeter, 1950) }\end{array}$ & $\begin{array}{l}\text { Um indivíduo que aplica } \\
\text { princípios de negócio para } \\
\text { resolver problemas sociais. }\end{array}$ \\
\hline $\begin{array}{l}\text { Distribuição de } \\
\text { riqueza }\end{array}$ & Acionista & Acionista e/ou Stakeholders \\
\hline $\begin{array}{l}\text { Forma de organização } \\
\text { predominante }\end{array}$ & Lucrativo & Lucrativo ou não lucrativo \\
\hline Objetivo primário & Económico & Mudança social \\
\hline Produto & $\begin{array}{l}\text { Criar e distribuir produto ou } \\
\text { serviço ao consumidor }\end{array}$ & Promover a mudança social \\
\hline Tensões & $\begin{array}{l}\text { Crescimento versus } \\
\text { sobrevivência }\end{array}$ & $\begin{array}{l}\text { Sustentabilidade económica } \\
\text { versus missão social }\end{array}$ \\
\hline
\end{tabular}

Tabela 4 - Diferenças entre empreendedorismo comercial e empreendedorismo social Fonte: Adaptado de Dacin et al, 2010, p. 44 


\section{Metodologia}

\subsection{Definição do Problema}

Nos capítulos anteriores foi contextualizado o conceito de empreendedorismo comercial e foram exploradas as motivações subjacentes a este fenómeno. Estudou-se, igualmente, o fenómeno de empreendedorismo social, percebendo por um lado aquilo que o assemelha ao empreendedorismo tradicional e o que o torna único. Como já foi referido na introdução, o estudo das motivações no empreendedorismo social é ainda muito escasso e necessita ser melhor explorado, contudo existem autores que já procuraram fazer algumas referências a este tema.

Poderíamos pensar, em primeiro lugar, que a motivação de um empreendedor para ingressar numa aventura de índole social seria precisamente a prossecução de uma meta social, ao contrário de um empreendedor comercial que procura obter lucro. Embora alcançar valor social seja claramente, e como já vimos anteriormente, um objetivo dos empreendedores sociais, ele pode não constituir o único fator de motivação, tal como verificamos que obter lucro não é o único fator de motivação dos empreendedores convencionais.

$\mathrm{Na}$ verdade não podemos ver o empreendedorismo comercial e $\mathrm{o}$ empreendedorismo social de forma tão dicotómica, pensando que aquilo que os distingue é a questão financeira ou social. Em boa medida, os motivos para o empreendedorismo social também incluem razões menos altruístas como a realização pessoal (Mair \& Martí, 2006; Hall et al, 2012). Outros autores corroboram esta ideia e, embora o seu estudo não se foque nas motivações no empreendedorismo social, eles acrescentam que os empreendedores sociais são motivados por um forte desejo de mudar a sociedade, um desconforto com o status quo, sentimentos altruístas e uma necessidade de serem socialmente responsáveis (Mair \& Noboa, 2005). Steinerowski et al (2008) sugerem ainda a motivação "paixão", ou seja, o querer marcar a diferença na vida das pessoas, como sendo um fator de motivação para o empreendedor social. Miller et al (2012) defendem que determinadas emoções como a compaixão, podem estar relacionadas com a motivação para o empreendedorismo social. Eles argumentam que a compaixão pode ajudar os indivíduos a atingirem a realização de 
ajudar o próximo através da criação de negócios que acumulam riqueza económica e social. Para estes autores, indivíduos com altos níveis de compaixão darão especial importância no seu processo de decisão aos benefícios de aliviar o sofrimento dos outros e, como tal, a compaixão providencia o impulso necessário para agir (Miller et al, 2012). No mesmo estudo, os autores defendem que a decisão de fundar uma empresa social depende da perceção do indivíduo de que o empreendedorismo social pode ser um meio para atingir os seus desejos (Miller et al, 2012).

Shaw e Carter (2007) procuraram, no seu estudo, conhecer e explorar as características dos empreendedores sociais, nomeadamente através da compreensão dos antecedentes históricos e as suas práticas atuais e da comparação com os empreendedores comerciais. Assim, embora este estudo não se foque nas motivações as autoras referem que as motivações divergem de empreendedores sociais para comerciais (Shaw \& Carter, 2007). Dão destaque ao facto de apenas uma pequena percentagem de empreendedores sociais darem importância aos fatores "tornar-se o seu próprio chefe e ser independente" e "criar segurança financeira pessoal" ao contrário dos empreendedores comerciais que foram caracterizados na literatura como sendo motivados por uma grande necessidade de realização e autonomia (McClelland, 1961 cit. Shaw \& Carter, 2007). A sua investigação revelou ainda que para a maioria dos empreendedores sociais o reconhecimento de uma falha na provisão de serviços ou uma necessidade social desconhecida foram a força chave na criação e desenvolvimento do seu projeto social (Shaw \& Carter, 2007). Ademais, o desejo de provocar a mudança e fazer a diferença, de ir ao encontro de necessidades sociais locais e resolver um problema social específico foram razões repetidas pelos seus entrevistados como constituindo fatores de motivação chave (Shaw \& Carter, 2007).

O objetivo geral da presente dissertação consiste assim em compreender e explorar as motivações dos empreendedores sociais para criarem, desenvolverem e se manterem num empreendimento social, sendo as questões de investigação:

- O que motiva os indivíduos a iniciarem um empreendimento de âmbito social?

- As motivações para o empreendedorismo social dos entrevistados diferem das motivações para o empreendedorismo tradicional encontradas na literatura? 
- Qual o impacto da motivação no processo de desenvolvimento do projeto, nomeadamente, quais são os obstáculos, expectativas e alteração nas motivações ao longo do tempo?

\subsection{Estratégia metodológica de investigação}

"A geração de novas teorias é geralmente fruto de um processo concetual e qualitativo (...) e precisamos de teoria para tornar a realidade em algo compreensivel para que nos possamos adaptar a ela e geri-la. Esta teoria pede dados num determinado contexto, ou seja, a teoria é um mapa e um bom mapa permite navegar num território desconhecido

para o viajante."

(Gummesson, 2005, p.318)

Esta investigação baseia-se num estudo qualitativo de natureza exploratória. As abordagens qualitativas são peculiarmente úteis em áreas que não estão muito desenvolvidas teoricamente (Edmondson and McManus, 2007), o que se revela particularmente pertinente no estudo das motivações para o empreendedorismo (Shaw \& Carter, 2007; Amit \& Muller, 1995). Lee et al (1999) mostraram que os dados qualitativos são úteis para gerar, elaborar e até testar teorias, no sentido de inspirar outros investigadores a procurarem oportunidades para expandir o seu pensamento e investigação (cit. Edmondon \& McManus, 2007). Ademais, os métodos de pesquisa qualitativos dão uma importância decisiva à compreensão das ações dos participantes na base das suas experiências de vida (Burgess, 1984 cit. Moreira, 1994), "permitem indicar por que razão o indivíduo se comporta de certa forma e responde aos vários estímulos" (...) e oferecem uma abordagem aberta, flexível e experimental “(Milliken, 2001, p.75).

A investigação qualitativa neste estudo pode ainda ser justificada pelo trabalho dos autores Bogdan e Biklen (1994), que clarificam a pertinência do seu uso pelas suas características. A primeira característica definida por estes autores prende-se com o facto de "na investigação qualitativa a fonte direta de dados é o ambiente natural, constituindo o 
investigador o instrumento principal" (Bogdan e Biklen, 1994, p.47). Neste estudo, privilegiou-se o contacto direto com os empreendedores sociais através das entrevistas pessoais. Em segundo lugar, "investigação qualitativa é descritiva" (Bogdan \& Biklen, 1994, p. 48), ou seja, os dados recolhidos são palavras, frases, pensamentos e representações das pessoas entrevistadas, e não dados numéricos, sendo cada entrevista tratada individualmente. A terceira característica prende-se com o facto de "os investigadores qualitativos se interessarem mais pelo processo do que simplesmente pelos resultados ou produtos" (Bogdan \& Biklen, 1994, p.49). Na verdade, nesta investigação prevalece o interesse em compreender o processo motivacional subjacente ao empreendedorismo existindo a conceção de que o mesmo se estende desde o momento remoto da intenção da criação do um projeto social passando pela própria criação e desenvolvimento do mesmo. Os autores referem uma quarta característica, "os investigadores qualitativos tendem a analisar os seus dados de forma indutiva" (Bogdan \& Biklen, 1994, p.50). Considerando a já referida falta de estudos empíricos sobre a motivação em empreendedorismo social, não se assumiu no início da investigação que se conheciam as grandes questões deste estudo, pautando-se todo o processo de investigação pela procura de compreensão e descoberta em relação à temática, com base no que os empreendedores sociais entrevistados poderiam evidenciar. Por último, os autores referem que "o significado é de importância vital na abordagem qualitativa" (Bogdan \& Biklen, 1994, p.50). Foi preocupação deste estudo ouvir, conhecer e problematizar o que motiva os empreendedores sociais a iniciarem os seus projetos e explorar o processo de empreendedorismo social em que se envolveram.

\subsubsection{Técnica de recolha de dados: entrevista}

Como técnica de investigação, e no sentido de se poderem conhecer e explorar as motivações de cada pessoa para o empreendedorismo social, interagindo oralmente com as pessoas, foram utilizadas as entrevistas semiestruturadas pessoais. Estas constituem um dos "métodos mais utilizados pelos investigadores da comunidade científica no âmbito das investigações com dados qualitativos" (Carson, Gilmore, Perry \& Gronhaug, 2001, p.73), 
uma vez que é flexível, acessível e inteligível; além disso, é capaz de revelar facetas do comportamento humano e organizacional que muitas das vezes são importantes mas desconhecidas (Qu \& Dumay, 2011).

De facto, as entrevistas pessoais constituem o método mais adequado para entrar no mundo das pessoas, compreender de perto as suas motivações e ter a possibilidade de abordar, de modo mais aprofundado o assunto, explorando as diversas questões motivacionais (Shaw \& Carter, 2007). Isto porque, no sentido de se compreender a motivação, a forma como veem o próprio empreendedorismo social, as dificuldades e obstáculos sentidos, a influência de determinados fatores na criação do seu projeto, é importante examinar de que forma os empreendedores sociais pensam, relembram e falam da sua experiência na criação e desenvolvimento do seu empreendimento. E, na verdade, são as entrevistas qualitativas que permitem que a pessoa conte a sua própria história, usando a sua própria linguagem (Moore, 2009). As questões abertas permitem que os entrevistados providenciem o seu próprio conhecimento e experiências pessoais (Moore, 2009).

As entrevistas semiestruturadas envolvem a preparação do entrevistador para as questões a colocar aos entrevistados, devendo estas ser guiadas por temas identificados de forma consistente e sistemática. Com base na revisão da literatura estabeleceram-se um conjunto de dimensões de análise a explorar, que permitiram a elaboração de um guião de entrevista (anexo 1). Na tabela 5 estão indicadas as dimensões técnicas de análise e as respetivas questões do guião. Este guião não é estanque, serve de referência e, no fundo, pretende apenas garantir que a mesma abordagem temática é aplicada durante a entrevista (Qu \& Dumay, 2011). Na verdade, essa é uma das vantagens do método de entrevista, já que ele permite que o entrevistador possa modificar o estilo, ritmo e ordem das questões no sentido de obter respostas mais completas do entrevistado (Qu \& Dumay, 2011). Esta margem para alterações foi fundamental em diversas entrevistas, tendo havido algumas situações em que foi realizada uma pergunta que previamente não estava prevista mas cuja necessidade surgiu com o decorrer da conversa e que se revelou importante para a elaboração dos resultados. 


\begin{tabular}{|c|c|c|}
\hline \multicolumn{2}{|c|}{ Dimensão de Análise } & Questões do guião \\
\hline $\begin{array}{l}\text { Entrada } \mathrm{n} \\
\text { empreendedora e }\end{array}$ & atividade & $\begin{array}{l}\text { Q1. Quando teve início a sua prática empreendedora e em que } \\
\text { iniciativas já esteve, ou não, envolvido. }\end{array}$ \\
\hline \multirow[t]{3}{*}{$\begin{array}{l}\text { Motivações na } \\
\text { criação do } \\
\text { empreendimento } \\
\text { social }\end{array}$} & $\begin{array}{l}\text { Fatores } \\
\text { motivacionais } \\
\text { push/pull }\end{array}$ & $\begin{array}{l}\text { Q3. Que projeto criou? (objetivos, missão, trabalho desenvolvido; } \\
\text { pessoas assalariadas, voluntários envolvidos, como se financia o } \\
\text { projeto, evolução em termos financeiros, clientes...). } \\
\text { Q4. Quais foram as suas principais motivações na criação deste } \\
\text { projeto? }\end{array}$ \\
\hline & $\begin{array}{l}\text { Vontade de ser o } \\
\text { próprio chefe }\end{array}$ & Q17. O que acha de ser o seu próprio chefe? \\
\hline & $\begin{array}{ll}\text { Propensão } & \mathrm{e} \\
\text { vontade } & \mathrm{de} \\
\text { correr riscos } & \end{array}$ & $\begin{array}{l}\text { Q18. Sente que há forte risco associado a este projeto? Que outras } \\
\text { situações na sua vida considera terem sido situações em que correu } \\
\text { risco? Gosta de correr riscos? }\end{array}$ \\
\hline $\begin{array}{l}\text { Alteração nas } \\
\text { motivações ao } \\
\text { longo do tempo }\end{array}$ & \multicolumn{2}{|c|}{$\begin{array}{l}\text { Q5. As motivações que teve para criar o seu projeto mantêm-se hoje em dia ou } \\
\text { alteraram-se? }\end{array}$} \\
\hline $\begin{array}{l}\text { Diferenças nas } \\
\text { motivações na } \\
\text { criação de um } \\
\text { empreendimento } \\
\text { empresarial (se } \\
\text { for o caso) }\end{array}$ & \multicolumn{2}{|c|}{$\begin{array}{l}\text { Q9. Já esteve envolvido na criação de algum projeto de empreendedorismo comercial? } \\
\text { Se sim, que motivações teve para o criar? São diferentes das que teve para criar este } \\
\text { projeto? } \\
\text { Q10. (se tiver respondido que não na questão 9) Porque criou uma iniciativa social e não } \\
\text { comercial? }\end{array}$} \\
\hline Reconhecimento & $\begin{array}{l}\text { Compreender se } \\
\text { a categoria } \\
\text { reconhecimento } \\
\text { foi uma } \\
\text { motivação para } \\
\text { criar o projeto } \\
\text { (push) }\end{array}$ & $\begin{array}{l}\text { Q12. Sente que o facto de ter o seu próprio projeto lhe confere um } \\
\text { reconhecimento que não teria anteriormente? Esta também foi uma } \\
\text { motivação para criar este projeto? E hoje em dia serve como fator } \\
\text { motivador? }\end{array}$ \\
\hline
\end{tabular}




\begin{tabular}{|c|c|c|}
\hline Realização & $\begin{array}{l}\text { Compreender se } \\
\text { a realização } \\
\text { profissional foi } \\
\text { uma motivação } \\
\text { para criar este } \\
\text { projeto. }\end{array}$ & $\begin{array}{l}\text { Q16. Sente-se realizado? A sua realização pessoal e/ou profissional } \\
\text { esteve dependente da criação deste projeto? }\end{array}$ \\
\hline \multirow[t]{5}{*}{ Expectativas } & $\begin{array}{l}\text { Compreender de } \\
\text { que forma as } \\
\text { expectativas da } \\
\text { pessoa a } \\
\text { influenciaram na } \\
\text { prossecução do } \\
\text { projeto }\end{array}$ & $\begin{array}{l}\text { Q6. Sempre teve expectativas de ter o seu próprio empreendimento? } \\
\text { Foi algo planeado? } \\
\text { Q7. Quais eram as suas expectativas iniciais face à criação do } \\
\text { projeto? Foram cumpridas? }\end{array}$ \\
\hline & $\begin{array}{l}\text { Razões de } \\
\text { escolha }\end{array}$ & Q2. Como surgiu a vontade de ser empreendedor? \\
\hline & $\begin{array}{l}\text { Escolha (valor: } \\
\text { realização, } \\
\text { utilidade, } \\
\text { intrínseco). }\end{array}$ & $\begin{array}{l}\text { Q14. Antes de criar o seu projeto já fez voluntariado nesta área? E } \\
\text { atualmente? Isso influenciou de alguma forma o projeto em que se } \\
\text { envolveu? }\end{array}$ \\
\hline & $\begin{array}{l}\text { Influência de } \\
\text { role models }\end{array}$ & $\begin{array}{l}\text { Q13.Possui outras pessoas na família/próximas que tenham criados } \\
\text { projetos empreendedores? (Ou outros empreendedores). Sente que } \\
\text { isso influenciou de alguma forma a sua vontade de prosseguir com } \\
\text { um projeto próprio? }\end{array}$ \\
\hline & $\begin{array}{l}\text { Aferir de que } \\
\text { forma a } \\
\text { perceção de } \\
\text { autoeficácia da } \\
\text { pessoa } \\
\text { influencia a } \\
\text { propensão para } \\
\text { criar um novo } \\
\text { negócio; } \\
\text { Explorar de que } \\
\text { forma os } \\
\text { obstáculos } \\
\text { influenciam a } \\
\text { vontade de } \\
\text { continuar com o }\end{array}$ & $\begin{array}{l}\text { Q19. Principais obstáculos com que se deparou no início da criação } \\
\text { do projeto? E hoje em dia? Como tem ultrapassado esses obstáculos? } \\
\text { Q20. Estava preparado para enfrentar essas dificuldades? Se não } \\
\text { estava, e se hoje soubesse que iria enfrentar essas dificuldades, } \\
\text { avançaria com o projeto na mesma? } \\
\text { Q21. Acha que esses obstáculos são suficientemente fortes para } \\
\text { inviabilizar as motivações de um potencial empreendedor social? }\end{array}$ \\
\hline
\end{tabular}




\begin{tabular}{|c|c|}
\hline & $\begin{array}{l}\text { projeto } \\
\text { (persistência) }\end{array}$ \\
\hline $\begin{array}{l}\text { Sucesso na } \\
\text { perspetiva do } \\
\text { empreendedor } \\
\text { social }\end{array}$ & $\begin{array}{l}\text { Q15. Acha-se bem-sucedido? Porquê? } \\
\text { Q22. Quais acha que devem ser as capacidades e competências de um empreendedor } \\
\text { social para obter sucesso? Sente que sempre as teve ou foi algo que adquiriu com o } \\
\text { tempo? (Como adquiriu essas competências?) }\end{array}$ \\
\hline $\begin{array}{l}\text { Representações } \\
\text { face às } \\
\text { diferenças entre } \\
\text { o empreendedor } \\
\text { comercial e } \\
\text { social }\end{array}$ & $\begin{array}{l}\text { Q8. Acha que existem diferenças entre um empreendedor comercial e um empreendedor } \\
\text { social? Quais? }\end{array}$ \\
\hline $\begin{array}{l}\text { Representação } \\
\text { de si próprio } \\
\text { enquanto } \\
\text { empreendedor } \\
\text { social e } \\
\text { conhecer as } \\
\text { características } \\
\text { dos mesmos }\end{array}$ & $\begin{array}{l}\text { Q11. Sente que é uma pessoa criativa? E inovadora? Porquê? } \\
\text { Q23. O que recomendaria a outros empreendedores sociais? } \\
\text { Q24. O que mudou em si? Que efeitos teve e o que tem representado para si ser um } \\
\text { empreendedor social? } \\
\text { Q26. Quais considera serem os aspetos positivos e negativos de ser um empreendedor } \\
\text { social? }\end{array}$ \\
\hline $\begin{array}{l}\text { Motivos para } \\
\text { desistir do } \\
\text { projeto ou do } \\
\text { empreendedoris } \\
\text { mo social }\end{array}$ & Q25. Razões que o poderiam levar a abandonar a prática. \\
\hline
\end{tabular}

Tabela 5 - Dimensões de análise do estudo e respetivas questões do guião de entrevista Fonte: Elaboração própria

\subsubsection{Procedimento para a recolha de dados}

O Instituto de Empreendedorismo Social em Portugal reconheceu e validou um conjunto de projetos de empreendedorismo social em Portugal. Procedeu-se ao estabelecimento de contactos com os empreendedores sociais desses projetos no sentido de marcar as entrevistas. As entrevistas realizaram-se entre os meses de maio e junho, nos 
locais de trabalho ou em casa dos entrevistados, contabilizando um total de 13 entrevistas individuais, com a duração máxima de $1 \mathrm{~h} 30$.

Todas as entrevistas foram realizadas presencialmente e gravadas (à exceção de duas que se realizaram por skype), de forma a preservar tudo o que foi dito e precaver que nada fosse esquecido na sua análise. Contudo, foram feitas anotações durante as entrevistas, para salvaguardar a informação em caso de avaria do gravador. Poder entrevistar as pessoas

presencialmente permite obter respostas mais precisas, maior interação com as pessoas e respostas mais refletidas (Shuy, 2002 cit. Moore, 2009). Contudo, o facto de todos os empreendedores sociais trabalharem, dificultou o processo de agendamento das entrevistas, implicando um maior espaçamento no tempo daquele que estava previsto inicialmente.

Todas as entrevistas foram transcritas na totalidade, o que se considerou um procedimento indispensável para a análise e comparação de dados posteriormente. Embora a identificação (nome) dos empreendedores sociais tenha sido permitida e esteja relacionada aos projetos, não será feita a referência, por pedido de anonimato, a quem disse o quê.

\subsubsection{Os entrevistados}

Os potenciais entrevistados foram inicialmente contactados através de e-mail com um sumário escrito com a apresentação da investigação e objetivos do estudo em questão. Todos os participantes foram identificados como empreendedores sociais, estando reconhecidos pelo Instituto de Empreendedorismo Social, como já referido, como tendo projetos de elevado potencial e cumprindo um conjunto de quatro requisitos:

1. Resolução de problemas sociais/ambientais negligenciados (Missão Social/ Ambiental)

2. Potencial de transformação positiva na sociedade a nível social/ambiental (Impacto social/ambiental)

3. Desafiando a visão tradicional e utilizando modelos de negócio inovadores (Inovação) 
4. Potencial de crescerem e/ou se replicarem noutro local geográfico (Escalabilidade/Replicabilidade)

(Instituto de Empreendedorismo Social, 2013)

O conjunto de entrevistas efetuadas reflete uma seleção natural dos empreendedores sociais derivada das suas disponibilidades e interesse em integrar o estudo, depois do convite formulado. Algumas entrevistas solicitadas foram recusadas ou inviabilizadas pela falta de tempo disponível em agenda para a entrevista. Os 13 projetos sociais e respetivos empreendedores sociais encontram-se descritos na tabela 6. Os empreendedores sociais entrevistados não pedem o anonimato face aos projetos mas pedem para não existir relação entre aquilo que disseram. Todos os projetos têm sido financeiramente sustentáveis até ao momento presente, sendo que uns são financiados pelo estado, outros por empresas, donativos, angariações de fundos e do dinheiro que fazem com o próprio trabalho realizado.

\begin{tabular}{|c|c|c|c|}
\hline $\begin{array}{c}\text { Nome do } \\
\text { Projeto }\end{array}$ & $\begin{array}{c}\text { Ano de } \\
\text { início do } \\
\text { projeto }\end{array}$ & $\begin{array}{c}\text { Empreen } \\
\text { dedor } \\
\text { social }\end{array}$ & Breve resumo do projeto \\
\hline 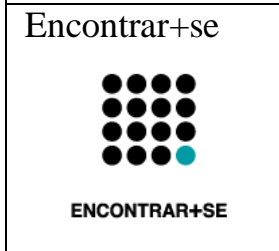 & 2006 & $\begin{array}{l}\text { Filipa } \\
\text { Palha }\end{array}$ & $\begin{array}{l}\text { A Encontrar+se desenvolve um amplo espectro de atividades em } \\
\text { torno da doença mental grave. Desenvolve investigação, } \\
\text { formação, sensibilização e assistência de forma a tornar o } \\
\text { ecossistema mais qualificado e amigável da pessoa com a doença } \\
\text { mental grave. }\end{array}$ \\
\hline $\begin{array}{l}\text { Programa } \\
\text { Aconchego } \\
\text { PROGRAMA \{ACONCHEGO\} }\end{array}$ & $\begin{array}{l}\text { Ano letivo } \\
2003 / 2004\end{array}$ & $\begin{array}{l}\text { Teresa } \\
\text { Branco }\end{array}$ & $\begin{array}{l}\text { O Aconchego é um programa que promove a convivência entre } \\
\text { séniores e jovens universitários através da partilha de residência } \\
\text { do idoso ao jovem estudante que se desloca para a cidade do Porto } \\
\text { para estudar no ensino superior. O projeto gera uma partilha } \\
\text { intergeracional. }\end{array}$ \\
\hline
\end{tabular}




\begin{tabular}{|c|c|c|c|}
\hline $\begin{array}{l}\text { Associação do } \\
\text { Porto de Paralisia } \\
\text { Cerebral }\end{array}$ & $\begin{array}{l}\text { Associaçã } \\
\text { o fundada } \\
\text { em } 1974 \\
\text { o projeto } \\
\text { implement } \\
\text { ado em } \\
2000\end{array}$ & $\begin{array}{l}\text { Abílio } \\
\text { Cunha }\end{array}$ & $\begin{array}{l}\text { A APPC é uma parceira empenhada das pessoas com paralisia } \\
\text { cerebral ou doenças neurológicas afins com a visão de os tornar } \\
\text { agentes efetivos da mudança. Instituiu no seu modelo de } \\
\text { funcionamento que as direções da instituição têm de ser } \\
\text { constituídas por três partes, incluindo encarregados de educação, } \\
\text { técnicos e as próprias pessoas com paralisia cerebral, como forma } \\
\text { de mudar o paradigma dos próprios e da sociedade. }\end{array}$ \\
\hline ColorAdd & 2010 & $\begin{array}{l}\text { Miguel } \\
\text { Neiva }\end{array}$ & $\begin{array}{l}\text { ColorAdd é um código de cores que permite aos daltónicos } \\
\text { identificar qualquer tipo e variante de cor. Este código está a ser } \\
\text { aplicado progressivamente em mais áreas, incluindo já a sua } \\
\text { utilização em lápis de cor, indicações de linhas de metro, } \\
\text { catálogos de tintas, roupas e mesmo em hospitais. }\end{array}$ \\
\hline$\frac{\text { Espaço }}{18 \text { anos }_{94}^{12}}$ & 1994 & $\begin{array}{l}\text { Jorge } \\
\text { Oliveira }\end{array}$ & $\begin{array}{l}\text { O Espaço T envolve o indivíduo em atividades artísticas formais e } \\
\text { não formais, estimulando as suas capacidades expressivas e } \\
\text { desenvolver o investimento em si próprio. Desenvolve a criação } \\
\text { de ligações duradouras com os seus alunos usando a arte como } \\
\text { veículo de comunicação e desenvolvimento. }\end{array}$ \\
\hline Fisiotrimtrim & 2011 & $\begin{array}{l}\text { Ana } \\
\text { Ferreira }\end{array}$ & $\begin{array}{l}\text { A equipa da Fisiotrimtrim presta serviços de babysitting } \\
\text { especializados no cuidado a crianças e jovens com necessidades } \\
\text { especiais. Nos cuidados que prestam, além de cuidarem, } \\
\text { direcionam a sua atividade para o estímulo à manutenção e } \\
\text { desenvolvimento de capacidades das crianças, constituindo-se } \\
\text { também como um suporte fundamental aos encarregados de } \\
\text { educação. }\end{array}$ \\
\hline NPISA & 2005 & $\begin{array}{l}\text { Paula } \\
\text { França }\end{array}$ & $\begin{array}{l}\text { O NPISA (Núcleo do Porto de Intervenção com os Sem-abrigo) é } \\
\text { uma rede de instituições que desenvolvem atividades para a } \\
\text { população sem-abrigo. Desenvolve um trabalho de articulação de } \\
\text { cuidados prestados e competências entre instituições, promovendo } \\
\text { a discussão e construção de um modelo de atuação e gestão } \\
\text { comum a toda a rede. }\end{array}$ \\
\hline $\begin{array}{l}\text { Projeto } \\
\text { RIOS } \\
\text { projetorios }\end{array}$ & 2005 & $\begin{array}{l}\text { Pedro } \\
\text { Teiga }\end{array}$ & $\begin{array}{l}\text { O Projeto Rios tem como principal eixo o apadrinhamento de um } \\
\text { troço de um rio por parte de um grupo de pessoas. Os grupos nas } \\
\text { suas visitas regulares às margens do rio recolhem um conjunto de } \\
\text { dados e fazendo algumas intervenção de melhoramento, que } \\
\text { depois enviam à equipa do Rios que assim as integra nas suas } \\
\text { bases de dados. }\end{array}$ \\
\hline
\end{tabular}




\begin{tabular}{|c|c|c|c|}
\hline Terra dos Sonhos & 2007 & $\begin{array}{l}\text { Frederico } \\
\text { Fezas } \\
\text { Vital }\end{array}$ & $\begin{array}{l}\text { A Terra dos Sonhos desenvolve todas as diligências de forma a } \\
\text { conseguir concretizar os maiores sonhos das crianças, jovens e } \\
\text { idosos em situação de carência ou estado grave de saúde. Desta } \\
\text { forma desenvolvem a crença das pessoas e famílias nos seus } \\
\text { sonhos criando um ambiente mais propício ao bem-estar e } \\
\text { qualidade de vida pessoal e familiar. }\end{array}$ \\
\hline $\begin{array}{l}\text { V.O.U. } \\
\text { Acompanhar }\end{array}$ & 2006 & $\begin{array}{l}\text { Sérgio } \\
\text { Vide }\end{array}$ & $\begin{array}{l}\text { O projeto VO.U Acompanhar incide sobre pessoas, que se verifica } \\
\text { que reincidirem em tratamentos hospitalares e cujas causas se } \\
\text { prendem com o não cumprimento de ordens médicas. Em } \\
\text { articulação com IPPSs locais, Hospital Santo António e ICBAS } \\
\text { desenvolvem um voluntariado que passa por visitas domiciliárias } \\
\text { a estas pessoas. }\end{array}$ \\
\hline Start Up Pirates & 2012 & $\begin{array}{l}\text { Inês } \\
\text { Santos } \\
\text { Silva }\end{array}$ & $\begin{array}{l}\text { Startup Pirates é um programa de aceleração de empreendedores } \\
\text { em potência com a duração de uma semana. Através de uma } \\
\text { combinação de conceitos teóricos, aplicação prática, exercícios, } \\
\text { apoio de mentores e desenvolvimento de ideias, apoia os } \\
\text { participantes na estruturação e desenvolvimento das suas ideias } \\
\text { para que ganhem forma. }\end{array}$ \\
\hline Vitamimos & 2007 & $\begin{array}{l}\text { Ana } \\
\text { Quintas }\end{array}$ & $\begin{array}{l}\text { A Vitamimos constitui um projeto inovador que tem como } \\
\text { principal objetivo intervir na prevenção da obesidade infanto- } \\
\text { juvenil, através da promoção de estilos de vida saudáveis. No } \\
\text { Espaço Vitamimos instalado na Quinta da Alagoa em Carcavelos } \\
\text { funciona um Centro de Educação Alimentar. }\end{array}$ \\
\hline $\begin{array}{l}\text { Percurso das } \\
\text { Memórias }\end{array}$ & 2012 & Ana Reis & $\begin{array}{l}\text { O percurso das memórias é um projeto de desenvolvimento do } \\
\text { turismo comunitário no centro histórico do Porto. Tem como } \\
\text { objetivo a preservação e divulgação da identidade sociocultural } \\
\text { deste território, dando a conhecer as tradições, memórias e } \\
\text { histórias deste local, através da realização de percursos } \\
\text { constituídos por atividades dinamizadas pela própria comunidade. }\end{array}$ \\
\hline
\end{tabular}

Tabela 6 - Empreendedores sociais entrevistados e respetivos projetos Fonte: Elaboração própria

As características demográficas e situação profissional dos entrevistados são apresentadas na tabela 7 . 


\begin{tabular}{|c|c|}
\hline Caracterização & Empreendedores sociais \\
\hline $\begin{array}{c}\text { Distribuição por sexo } \\
\text { Feminino } \\
\text { Masculino }\end{array}$ & $\begin{array}{l}7 \\
6\end{array}$ \\
\hline $\begin{array}{c}\text { Distribuição por faixa etária } \\
\text { 20-24 Anos } \\
\text { 25-29 Anos } \\
\text { 30-34 Anos } \\
\text { 35-39 Anos } \\
\text { 40-44 Anos } \\
\text { 45-49 Anos } \\
\text { 50-54 Anos }\end{array}$ & $\begin{array}{l}3 \\
1 \\
0 \\
0 \\
4 \\
4 \\
1\end{array}$ \\
\hline $\begin{array}{c}\text { Distribuição por habilitação académica } \\
\text { Ensino Secundário } \\
\text { Licenciatura } \\
\text { Mestrado } \\
\text { Doutoramento }\end{array}$ & $\begin{array}{l}1 \\
7 \\
3 \\
2\end{array}$ \\
\hline $\begin{array}{c}\text { Situação Profissional anterior ao projeto } \\
\text { Desempregado } \\
\text { Trabalhador por conta de outrem } \\
\text { Trabalhador por conta própria } \\
\text { Estudante }\end{array}$ & $\begin{array}{l}0 \\
7 \\
3 \\
3\end{array}$ \\
\hline $\begin{array}{c}\text { Situação Profissional atual } \\
\text { Desempregado } \\
\text { Trabalhador por conta de outrem } \\
\text { Trabalhador por conta própria } \\
\text { Estudante } \\
\text { [Exclusivamente no projeto] }\end{array}$ & $\begin{array}{l}1 \\
5 \\
7 \\
0 \\
5\end{array}$ \\
\hline $\begin{array}{c}\frac{\text { Aferimento de salário com o projeto }}{\text { Aufere de salário }} \\
\text { Aufere de salário no âmbito das suas funções }{ }^{8} \\
\text { Não aufere }\end{array}$ & $\begin{array}{l}5 \\
3 \\
5\end{array}$ \\
\hline
\end{tabular}

Tabela 7 - Perfil demográfico e profissional dos entrevistados

A distribuição dos entrevistados por sexo é relativamente semelhante, sendo a amostra constituída por 7 mulheres e 6 homens. Podemos verificar que as idades dos

\footnotetext{
${ }^{8}$ Alguns empreendedores sociais criaram projetos no âmbito das suas funções nas organizações onde desempenham a sua profissão.
} 
empreendedores sociais se situam entre os 20-29 anos e 40-54 anos, havendo um maior número de pessoas entre os 40 e os 49 anos. O grau de formação académica dos entrevistados é elevado, sendo que apenas um dos elementos não frequentou o ensino superior, três deles possuem mestrado e dois possuem doutoramento.

No momento anterior à criação do empreendimento, a maioria das pessoas trabalhava por conta de outrem. Atualmente a situação profissional é diferente, destacandose a maioria das pessoas como sendo trabalhador por conta própria, sendo que destes sete elementos, cinco deles se dedicam exclusivamente ao projeto. Quanto ao facto de auferirem ou não de rendimento, os resultados dividem-se já que cinco pessoas auferem e cinco não auferem, havendo ainda três empreendedores sociais que auferem de salário com o seu projeto pelo facto de este estar inserido no âmbito das suas funções.

\subsubsection{Análise de Dados}

Depois de efetuada a análise exploratória dos dados demográficos, e para o propósito desta investigação, os dados recolhidos das entrevistas foram analisados recorrendo-se à técnica da análise de conteúdo.

O lugar ocupado pela análise de conteúdo em investigação é cada vez maior porque esta permite tratar de uma forma metódica informações e testemunhos com um elevado grau de profundidade e complexidade (Quivy \& Campenhoudt, 2008). Esta abordagem define-se como "um conjunto de técnicas de análise das comunicações visando obter, por procedimentos, sistemáticos e objetivos de descrição do conteúdo das mensagens, indicadores (quantitativos ou não) que permitam a inferência de conhecimentos relativos às condições de produção/receção (variáveis inferidas) dessas mensagens” (Bardin, 1997, p.42). Tem como finalidade efetuar deduções lógicas e justificadas, referentes à origem das mensagens tomadas em consideração, neste caso o emissor e o seu contexto ou os efeitos das mensagens (Bardin, 1997). Esta técnica ajuda na revelação de novas temáticas e questões que se repetem e precisam de maior exploração (Edmondson \& McManus, 2007). Importa realçar que "a chave para a análise em investigação qualitativa é a comparação. Os dados são comparados com outros dados, com a teoria já existente e possíveis resultados 
que possam já existir de outras investigações. Esta comparação faz parte de um processo através do qual os conceitos, categorias e possivelmente teorias são formados" (Gummesson, 2005, p.312).

Para a construção do conhecimento e tal como sugerido pelos autores Quivy \& Campenhoudt (2008), são analisados os termos usados pelo entrevistado, a frequência de utilização e o seu modo de disposição, a construção do discurso e o seu desenvolvimento.

A análise de conteúdo das entrevistas desta investigação seguiu três fases: a préanálise, onde foi efetuada uma primeira leitura do material recolhido; a exploração do material, na qual foi efetuada a codificação dos dados; na terceira e última, o tratamento dos resultados obtidos e sua respetiva interpretação, tendo emergido novas categorias teóricas (Edmondson \& McManus, 2007).

A análise dos resultados e sua discussão constituirão os capítulos seguintes deste trabalho. 


\section{IV- Resultados e discussão}

Neste capítulo serão expostos os dados recolhidos junto dos empreendedores sociais entrevistados, procurando-se partir dos seus depoimentos para uma articulação com as reflexões teóricas do capítulo II.

Embora o anonimato não tivesse sido requerido pelos entrevistados e os projetos sociais estejam identificados, não existirá uma relação entre quem disse o quê a pedido dos mesmos, pelo que os depoimentos estarão apenas associados a uma sigla (ES) que designa Empreendedor Social e um número. Tendo por base a codificação dos dados anteriormente efetuada, é meu objetivo fazer uma leitura dos mesmos articulando categorias e subcategorias em que foram organizadas.

\subsection{Entrada na atividade empreendedora}

Um dos primeiros objetivos das entrevistas foi compreender de que forma surge o empreendedorismo social na vida dos entrevistados, isto é, se já se tinham envolvido em iniciativas empreendedoras anteriormente e explorar como surge o empreendimento social, a área em que se enquadra e o modo de financiamento do projeto.

\subsubsection{Fatores que despoletam o Empreendedorismo Social}

Os empreendimentos sociais na vida dos entrevistados surgem através de diferentes âmbitos, sendo de destacar a deteção de uma necessidade social, isto é, o facto de existir uma dada lacuna em determinada área, levou-os a pensar que podiam criar algo para colmatar essas falhas na sociedade. Na verdade, como já foi visto na revisão da literatura, os empreendedores sociais são pessoas que estão atentas ao que os rodeiam e que se focam nas necessidades à sua volta.

"Percebi que havia uma lacuna enorme nas escolas na área da educação alimentar" (ES3) 
"Comecei a perceber que o que faltava eram condições que pudessem disponibilizar às pessoas todo o conhecimento que nós temos e com isso fazer com que elas pudessem iniciar projetos de recuperação para maximizar o potencial (...)"(ES9)

A deteção de uma necessidade social não é o único fator que despoleta a criação de um empreendimento social já que alguns entrevistados que fizeram referência à mesma, enquadram-se também no âmbito da sua formação académica ou da sua prática profissional. Cerca de cinco dos empreendimentos surgiram associados à formação académica dos entrevistados.

"Surge muito ligado ao design, o projeto surge com a desculpa ou a ideia de desenvolver uma tese de mestrado ..." (ES1)

"Percebi que algo não resultava bem e que a grande falha era o facto de não ter envolvido, durante o projeto de mestrado, a comunidade envolvente (...)” (ES10)

Por outro lado, cinco outros empreendimentos surgem associados à prática profissional dos entrevistados.

"Nós já tínhamos trabalhado na área de intervenção comunitária (...) e sempre achamos, nós trabalhamos num contrato local de desenvolvimento social e sempre achámos que havia projetos muito interessantes mas que não tinham uma vertente de grande sustentabilidade” (ES7)

\subsubsection{Envolvimento em iniciativas empreendedoras anteriormente}

O empreendedorismo na vida dos entrevistados não é uma novidade para alguns elementos, sendo que três dos entrevistados estiveram já envolvidos em iniciativas de empreendedorismo comercial.

"Tive uma editora, tive uma agência de design, tive uma agência de modelos, fui diretor de marketing, fiz um projeto ligado à vela...” (ES13) 
"Tive, aquele negócio de família, em que nos últimos anos era praticamente eu que geria" (ES5)

Uma das entrevistadas esteve já envolvida em iniciativas de empreendedorismo comercial e de empreendedorismo social.

"Aos 18 anos iniciei uma atividade na área da cerâmica, e sempre tive dividendos com isso e ainda tenho (...) Neste momento tenho dois projetos paralelos onde tenho receitas, fora a minha atividade. O [projeto] é um, entre muitos, daqueles que eu desenvolvi e criei sendo que este foi muito acarinhado pela comunicação social mas já tive projetos tão ou mais interessantes. Já tive milhões de projetos na área social" (ES6)

Os restantes nove entrevistados relatam não terem estado envolvidos em nenhum tipo de iniciativas de empreendedorismo (comercial ou social), contudo referem ter estado sempre ligados à área social ou à causa do projeto em si.

“Não tive, sempre tive ligado a causas humanistas, artísticas..." (ES2)

"Sempre trabalhei por conta de outrem, para o Estado, fui professora no ISSSP mas não foi isso que caracterizou a minha atividade profissional; aquilo que me caracteriza a atividade profissional é o trabalho na comunidade, nas comunidades onde fui passando" (ES11)

\begin{tabular}{|l|c|}
\hline Envolvimento anterior em iniciativas empreendedoras & Entrevistados \\
\hline Iniciativas de empreendedorismo comercial & 3 \\
\hline Iniciativas de empreendedorismo comercial e social & 1 \\
\hline Sem envolvimento em iniciativas empreendedoras & 9 \\
\hline
\end{tabular}

Tabela 8 - Envolvimento dos entrevistados em iniciativas empreendedoras

\subsubsection{Modo de financiamento do projeto}

O financiamento deste tipo de empreendimentos nem sempre é fácil conseguir e é uma preocupação acrescida que os empreendedores sociais têm de ter para além das questões sociais. Embora o modelo de empresa social tivesse sido referido como o desejo 
de alguns dos empreendedores sociais, a realidade é que o modo de financiamento dos projetos entrevistados ainda não passa por aí. Assim, a maioria dos empreendedores garante o financiamento dos seus projetos através de diversas fontes, tendo sido referidas as candidaturas a projetos, o mecenato social, as doações, áreas dentro do projeto que produzem receita, prestação de serviços, campanhas de marketing e financiamento do próprio estado.

"Os financiadores, da segurança social, educação, ex-dren, da saúde e financia-se com comparticipação dos clientes e através do mecenato social também” (ES5)

"Ficamos com 10\% das receitas de todos os eventos ou todos os programas que são organizados por nós, temos sponsors e agora estamos a desenvolver as áreas de financiamento como consultoria, formação" (ES8)

Somente um dos empreendedores sociais refere ter recorrido apenas a financiamento próprio, tendo para isso abdicado dos seus próprios bens para iniciar o seu projeto e tendo depois criado um modelo hibrido, ou seja, em que uma parte do projeto não tem fins lucrativos e a outra parte tem com o objetivo de recuperar o investimento próprio feito inicialmente.

“O que tive que fazer foi arranjar capital para investir (...) Então na altura em 2007, ainda se vendiam casas e vendi a minha casa. E então com o dinheiro da casa eu construi o espaço. Crio uma unipessoal, uma maneira de eu um dia, com algum lucro que pudesse gerar, recuperar o investimento feito. E depois em paralelo, o que eu fiz foi criação uma associação sem fins lucrativos, por isso neste momento somos híbridos, ou seja, sou uma unipessoal proprietária do espaço e que tem que ter a preocupação de gerar receitas para recuperar o investimento feito ali" (ES3)

\subsection{4. Área social do empreendimento}

Paralelamente ao modo como as pessoas se envolveram no seu projeto, também as áreas dos empreendimentos sociais estão geralmente associadas ora à área de formação da 
pessoa, ora à área onde exercem a sua profissão, que acabam no fundo por se interligar de alguma forma se pensarmos que a tendência é as pessoas trabalharem na sua área de formação académica.

"Na escola sempre tive ligada a projetos de promoção da saúde” (ES3)

"Nós gostamos muito da parte das histórias e de conhecer as pessoas e de capacitar pessoas também na questão por isso temos trabalhado bastante nesta área” (ES7)

\subsection{Expectativas}

Como vimos na literatura, as expectativas que o empreendedor possui podem influenciar o esforço que vai despender na sua ação na procura dos resultados desejados. Assim, foi objetivo perceber, junto dos entrevistados, quais eram as suas expectativas, nomeadamente se havia de facto a expectativa de terem o seu próprio empreendimento e se as que tinham face á criação do mesmo foram ou não cumpridas.

\subsubsection{Expectativas de ter empreendimento próprio}

No que concerne à expectativa de ter o seu próprio empreendimento, as respostas dividem-se, sendo que metade dos empreendedores sociais afirmam não ter essa expectativa.

"Não, isso foi uma coisa que surgiu naturalmente. Ainda hoje não me vejo como um empreendedor, vejo-me como uma pessoa que com uns colegas decidiu criar alguma coisa” (ES12)

“Não...eu aliás quando comecei a planear a minha vida na adolescência, pensei ser um carneiro igual aos outros. Portanto, incluir uma carreira, fosse ela qual fosse, com estatuto, salário bom, um carro, uma casa (...) (ES13)

A outra metade refere sempre ter tido a vontade e a expectativa de ter o seu próprio empreendimento. 
"Sim, sempre tive expectativas de ter o meu próprio projeto" (ES7)

“É assim, eu sempre tive essa vontade de criar as minhas próprias coisas (...), eu percebi que o meu objetivo da vida era criar as minhas próprias empresas, criar os meus próprios projetos, não trabalhar para ninguém (ES8)"

\begin{tabular}{|l|l|}
\hline Sim & Não \\
\hline $50 \%$ & $50 \%$ \\
\hline
\end{tabular}

Tabela 9 - Expectativas de ter empreendimento próprio (\%)

\subsubsection{Expectativas na criação do projeto}

Esta questão é vista de forma muito positiva por todos os entrevistados já que nenhum referiu não terem sido cumpridas as suas expectativas. Pelo contrário, $70 \%$ dos inquiridos referem ter sido superadas, principalmente no que diz respeito ao crescimento que todos os projetos tiveram e que não tinha sido planeado.

"Ultrapassadas largamente. Nunca imaginei que isto que começou por um projeto de investigação, se tornasse nacional" (ES10)

"Está a exceder as minhas expetativas, nunca pensei que isto fosse chegar onde chegou. Acreditei sempre como acreditei em todos os projetos onde estive (...) quando comecei este projeto achei que era assim uma coisa que envolveria algumas instituições principais da cidade, que não crescesse muito em termos de parcerias porque é um tema muito quente” (ES11)

"Começou com uma ideia, um pequeno conceito que queríamos experimentar e ver se resultava e que excedeu imenso as nossas expectativas" (ES12)

Os restantes $30 \%$ referem ter sido cumpridas ao fim de algum tempo, sendo que as dificuldades (que veremos mais à frente) que foram surgindo não permitiram afirmar que 
as expectativas tivessem sido logo cumpridas mas que está a ser um processo positivo em construção.

"Eu acho que ainda estão a ser. Isto ainda está a evoluir, todos os dias é uma luta, sem saber se vamos conseguir. Ainda está a ser uma construção. Mas se eu estou a gostar de fazer, estou. E dá-me muito gozo (...) Sim está a corresponder, está a ser uma viagem gira” (ES4)

"Para já tem sido extremamente positivo o projeto e tem correspondido imenso ás nossas expectativas (...) e se calhar gostariamos de já estar formadas até como associação e se calhar até algum rendimento superior para conseguirmos trabalhar mais tempo no projeto, mas demora, demora tempo" (ES7)

\subsection{Obstáculos e dificuldades}

Um dos objetivos desta investigação foi também explorar de que forma os obstáculos poderão ou não constituir uma barreira na prossecução do projeto, e desta forma, criar um impacto na motivação que o empreendedor social tem para desenvolver o seu empreendimento. Assim, procurou-se conhecer os obstáculos enfrentados no início da criação do projeto e os atuais e de que forma eles são ou não ultrapassados.

\subsubsection{Obstáculos enfrentados na criação do empreendimento social}

Quando questionados acerca dos obstáculos que enfrentaram na criação do seu empreendimento a mobilização de recursos financeiros e humanos e a burocracia aliada ao processo foram os mais mencionados. Contudo, as respostas são muito divergentes já que outros obstáculos surgiram e são apresentados na tabela 10.

\begin{tabular}{|c|c|c|}
\hline Obst: & Depoimento & $\%$ \\
\hline $\begin{array}{c}\text { Mobilização de } \\
\text { recursos } \\
\text { humanos } \\
\text { /financeiros }\end{array}$ & $\begin{array}{l}\text { "Um foi ... a parte financeira é sempre um bocado”(ES2) } \\
\text { "No início, recursos humanos. Como nós próprios. Porque la está, não } \\
\text { podíamos estar a } 100 \% \text {, mas ao mesmo tempo queríamos avançar com as } \\
\text { coisas para a frente" (ES4) } \\
\text { "Primeiro como se juntam pessoas; e como se põe pessoas a trabalhar }\end{array}$ & 35,7 \\
\hline
\end{tabular}




\begin{tabular}{|c|c|c|}
\hline & $\begin{array}{l}\text { sem fundos económicos" (ES10) } \\
\text { "Sobretudo ao nível da sustentabilidade, ou seja, a dificuldade de } \\
\text { conseguir recursos numa fase de arranque para a sustentabilidade do } \\
\text { projeto e eu acho que é aí que empatam a maioria dos projetos" (ES13) }\end{array}$ & \\
\hline Burocracia & $\begin{array}{l}\text { "As partes burocráticas demoraram imenso tempo para ser reconhecida } \\
\text { como IPSS na área da saúde para poder recorrer a financiamentos" } \\
\text { (ES9) } \\
\text { "Acho que os obstáculos foram sempre os mesmos...é a falta de rigor do } \\
\text { cumprimento das obrigações institucionais por parte do estado(...)e na } \\
\text { altura o ministro anunciou financiamentos que nunca saíram (...) Os } \\
\text { serviços são muito burocratizados em Portugal” (ES11) } \\
\text { "O trabalho máximo foi a instalação, porque é Portugal, porque é uma } \\
\text { loucura de burocracias (...)” (ES3) }\end{array}$ & 21,4 \\
\hline Inovação & $\begin{array}{l}\text { "O segundo foi talvez a inovação, pelo facto de fazer arte com todos os } \\
\text { utentes à mistura" (ES2) } \\
\text { "Depois o enquadramento legal de coisas que são inovadoras, é um país } \\
\text { completamente quadrado, se não encaixar lá num quadradinho qualquer, } \\
\text { os técnicos que estão a atender já não sabem o que fazer...o melhor é } \\
\text { chumbar e não fazer nada. Outra questão é essa, a dificuldade de } \\
\text { inovar" (ES3) }\end{array}$ & 14,2 \\
\hline Comunicação & $\begin{array}{l}\text { "A questão da comunicação ...porque a comunicação e fundamentalmente } \\
\text { por confiança (...) A comunicação sempre foi um problema. Todo o resto } \\
\text { dos procedimentos, a forma como está agilizado, nada...” (ES6) }\end{array}$ & 7 \\
\hline $\begin{array}{l}\text { Gestão do } \\
\text { tempo }\end{array}$ & $\begin{array}{l}\text { "Acho que o maior risco é aquela questão da balança, não termos o } \\
\text { tempo que gostaríamos para disponibilizar para o projeto. E nós } \\
\text { costumamos dizer que se nós não investirmos tudo agora que estamos } \\
\text { numa fase de construção, e se deixarmos perder que o projeto morre" } \\
(\text { ES7) }\end{array}$ & 7 \\
\hline $\begin{array}{l}\text { Tomada de } \\
\text { decisão }\end{array}$ & $\begin{array}{l}\text { "É preciso tomar uma decisão de que é isto que se quer fazer, } \\
\text { principalmente quando começamos como um hobby, depois temos que } \\
\text { tomar a decisão que, pronto, é isto que quero fazer e vou dedicar os } \\
\text { próximos anos a isto, é uma decisão que tem que ser tomada e } \\
\text { obviamente não é fácil" (ES8) }\end{array}$ & 7 \\
\hline
\end{tabular}




\begin{tabular}{|c|l|c|c|}
\hline & "Podia ter criado um modelo ad hoc, novo, inovador, que fosse & \\
Falta de & diretamente às convicções e pressupostos. Qual era o problema, a & \\
notoriedade e & ameaça? Ninguém me conhece no mercado dos projetos sociais, ninguém \\
credibilidade/ & sabe quem eu sou, nunca dei provas portanto eu primeiro preciso & \\
Inexperiência & estabelecer alguma notoriedade e credibilidade” (ES13) & 7 \\
na área & "Talvez um bocadinho os meus próprios condicionamentos internos, a & \\
& $\begin{array}{l}\text { limitação que eu tinha por não conhecer o meio ambiente e os projetos } \\
\text { sociais" (ES13) }\end{array}$ & \\
&
\end{tabular}

Tabela 10 - Obstáculos dos empreendedores sociais na criação do empreendimento

\subsubsection{Superação de obstáculos}

No discurso dos entrevistados percebemos que todos eles conseguiram meios alternativos para ultrapassarem as dificuldades mencionadas. Não se pode afirmar que exista um truque ou uma fórmula, mas que existe uma vontade de os ultrapassar isso sim, e a forma como eles são ultrapassados permite-nos afirmar que estes empreendedores sociais mostram características de persistência, resiliência e criatividade para encontrar soluções. Assim, o facto de terem aparecido estes obstáculos, não foram um mote para desistir ou perder a motivação. Os empreendedores sociais procuraram fontes de financiamento alternativas $(40 \%)$, construir uma boa rede de contactos $(20 \%)$, encarar os problemas de forma positiva (20\%) e agarrar em modelos de projetos já existentes (20\%), adaptando para dar credibilidade aos seus próprios projetos.

"Daí eu ter decidido agarrar num modelo que já era credível, já era conhecido, embora com um pequeno upgrade do modelo e no fundo era uma réplica com um upgrade do modelo que já existia e ninguém punha em dúvida” (ES13)

“Os obstáculos têm sido ultrapassados... trabalhando, também temos uma boa rede de...temos criado uma boa rede de contatos, pessoas que nos têm ajudado (...) ao abrirmos o projeto a outras pessoas e outras pessoas terem dados outros contatos, contribuintes até para o nosso projeto, e outros projetos quererem aliar-se connosco na construção, acaba por haver uma ajuda mútua" (ES7) 


\subsubsection{Preparação para enfrentar obstáculos}

Quando inquiridos sobre esta questão, metade dos entrevistados refere ter estado preparado para enfrentar os obstáculos referidos anteriormente, sendo que, mais uma vez, o facto de terem estes obstáculos não foi um mote para não lutar pelos seus objetivos.

"Sim ...hum ...como hei-de dizer, apesar de serem obstáculos, não eram obstáculos que me impediam de lutar e eu sempre fui muito determinado" (ES2)

"Acho que sim, acho que nunca senti que não tivesse e acho que o facto de também sentir isso ajudou a não tê-los" (ES13)

Pelo contrário, a outra metade de entrevistados refere não se ter sentido preparado, na altura da criação do projeto, para enfrentar os obstáculos mencionados.

"Não, claramente. Quer dizer... não. Não, achamos se calhar no início que seria mais fácil. Mas depois á medida que nos fomos apercebendo que a coisa era assim, tivemos que tomar decisões". (ES4)

"Eu acho que nós nunca estamos preparados porque nunca sabemos o que é que nos vai acontecer e que imprevistos é que vão surgir..."(ES7)

Dos empreendedores que referem não estar preparados, quase todos afirmam que teriam avançado na mesma com o projeto se tivessem tido conhecimento das dificuldades que iriam enfrentar, reforçando que o processo poderia ter sido diferente se houvesse este conhecimento e que o facto de terem tanta paixão pelo seu trabalho acaba por anular o sentimento mais negativo que possa existir face às dificuldades encontradas no percurso.

“Ai avançava sem dúvida (...) Porque ás vezes, não vou negar, que ás vezes mesmo nós entre equipa dizemos, os caminhos são duros (...) mas acabamos por ter tanta paixão por aquilo 
que fazemos, e trabalhar com a comunidade e com as pessoas, que isso acaba por ser superado" (ES7)

Apenas um dos entrevistados refere que não avançaria com o projeto se tivesse conhecimento dos obstáculos que iria encontrar na criação do seu projeto.

"As dificuldades são muito maiores do que eu imaginava e ainda bem que eu não imaginava, eu acho que é assim com qualquer empreendedor, ainda bem que nós empreendedores, quando começamos uma iniciativa, somos ingénuos e não temos a mínima noção das dificuldades... o ser naive e não ter experiência é uma coisa boa até (... ) ainda bem que eu não sabia que ia estar 4 anos a tentar construir, que vinha uma crise destas que nunca mais me tinha metido nisto" (ES3)

\subsubsection{Obstáculos atuais}

O crescimento de qualquer projeto traz, obviamente, outro tipo de preocupações acrescidas, inerentes a esse próprio crescimento e a tudo a que ele está associado. Neste estudo não há exceção, sendo que é interessante perceber que a maioria dos obstáculos atuais que os empreendedores sociais enfrentam estão de facto relacionados com o crescimento do projeto, ou seja, associados ao facto de este ter mais pessoas, exigindo por isso uma melhor gestão das mesmas e requerer mais tempo disponível. Também a questão dos recursos financeiros é muito referida, havendo uma clara associação com a crise económica e financeira que o país atravessa e que afeta os financiamentos dos projetos. Na tabela 11 apresentam-se os depoimentos que ilustram os obstáculos atuais.

\begin{tabular}{|c|l|}
\hline Obstáculos atuais & \multicolumn{1}{c|}{ Depoimento } \\
\hline Gestão do tempo & $\begin{array}{l}\text { "Responder a tempo, com competência e com solução. Hoje obriga-nos a } \\
\text { estarmos mais atentos, ter mais cuidados, toda uma serie de personagens } \\
\text { que se enveram que me obrigaram a não mudar o registo" (ES1) } \\
\text { "Gostaria de ter mais tempo para disponibilizar para o projeto (...)" } \\
(E S 7)\end{array}$ \\
\hline
\end{tabular}




\begin{tabular}{|c|l|}
\hline \multirow{2}{*}{ Recursos financeiros } & $\begin{array}{l}\text { "Neste momento estamos também a tentar arranjar fontes de } \\
\text { sustentabilidade porque com a crise tornou-se mais dificil" (ES2) }\end{array}$ \\
& $\begin{array}{l}\text { "Tem tantas preocupações na parte de negócio da sustentabilidade } \\
\text { financeira que estou com menos tempo e conseguir fazer menos e do lado } \\
\text { da medição do impacto" (ES3) }\end{array}$ \\
\hline $\begin{array}{c}\text { Gestão e motivação } \\
\text { de pessoas }\end{array}$ & $\begin{array}{l}\text { "É as equipas com quem estou a trabalhar, eu coordeno, recruto, } \\
\text { basicame conseguir que atrás de mim venham outros malucos que } \\
\text { adiram aoto" (ES3) }\end{array}$ \\
\hline
\end{tabular}

Tabela 11 - Obstáculos atuais enfrentados pelos empreendedores sociais

\subsubsection{Superação dos obstáculos atuais}

Os obstáculos atuais, paralelamente aos obstáculos já enfrentados, continuam a ser ultrapassados por todos os empreendedores, que continuam na procura de soluções alternativas e possuem características de liderança, autoestima e resiliência que os fazem prosseguir com a sua iniciativa. Assim, é possível referir que os obstáculos não constituem um meio para desistir do projeto.

“Isso só é conseguido se transmitires confiança, paixão, honestidade e isso é uma maneira de viver" (ES1)

"E por isso estamos todos os meses a pensar em ideias novas para não depender tanto do estado e passar a ter fontes de financiamento nossas (...) Queremos abrir mais duas filiais (...) vamos saber muito em breve se conseguimos o dinheiro e se financiarem alguns técnicos daqui vão para lá, podemos abranger mais pessoas e isso é que é a nossa vontade. Agora estou preocupado em arranjar soluções para resolver isso (...) em vez de me queixar penso em coisas positivas e alternativas" (ES2) 


\subsubsection{Impacto dos obstáculos na motivação de um potencial empreendedor social}

Compreender a perceção que os empreendedores sociais possuem face a esta questão foi também um objetivo do estudo. Quando questionados, cerca de 40\% dos inquiridos referem que os obstáculos poderão influenciar a motivação de um potencial empreendedor social hoje em dia.

"Acho. Primeiro há pessoas que não conseguem fazer essa transição, e por outro lado, há pessoas que tem mais dificuldade em definir objetivos e trabalhar em projetos sem perceber onde é que aquilo vai dar "(ES8)

"Sim eu penso que é muito difícil criar um projeto e é preciso mesmo muita força de vontade "(ES12)

Cerca de $60 \%$ dos entrevistados referem que os obstáculos não impactam na motivação do empreendedor social, e inclusive alguns elementos fazem referência ao facto da própria motivação ser um determinante neste sentido.

"Não, depende da sua motivação (...) Inovação social dá que é preciso mudar mentalidades e tu não mudas num dia" (ES1)

"Não inviabiliza...eu acho que quando uma pessoa tem autodeterminação e quer mesmo fazer uma coisa, e se faz aquilo que gosta com alguma paixão, as soluções aparecem" (ES3)

\subsection{Sucesso na perspetiva do empreendedor social}

Foi também importante explorar a questão do sucesso na perspetiva do empreendedor social, ou seja, o foco não é investigar o sucesso do empreendimento social, esse seria outro possível tema de investigação, mas sim compreender a perceção que o empreendedor tem do seu próprio sucesso e em que sentido isso pode ou não influenciar a motivação para continuar no seu projeto, bem como aquilo que o empreendedor social acha que pode ser necessário para obter sucesso. 


\subsubsection{Sucesso como percurso individual}

Cerca de $46 \%$ dos entrevistados afirmam sentirem-se bem-sucedidos, principalmente pelo facto de estarem a fazer algo que gostam; há uma associação ao percurso profissional que têm tido e ao projeto que construíram, como se pode ler nos seus depoimentos.

"Acho que sou uma pessoa que tenho sorte de fazer coisas boas que me dão um resultado bom, aquilo que eu quero; acho que sou bem-sucedido porque trabalho muito (...) por isso acho que sou uma pessoa quase 100\% feliz" (ES2)

"Eu acho que sim, só precisava de conseguir aqui a parte financeira mais desafogada, mas está bem, não está mal, mas sim considero-me, estou a fazer aquilo que queria, está a acontecer" (ES3)

Porém, é interessante perceber que quando inquiridos sobre esta questão, dois elementos remetem a sua perceção de ser bem-sucedido para aquele que consideram ser o sucesso do seu próprio empreendimento, sendo que um dos entrevistados já havia referido sentir-se bem-sucedida a nível pessoal anteriormente (ES3).

"É um desafio grande mas estou a adorar o desafio e para mim já é sucesso porque há muitos shinning eyes à minha volta, tanto dos miúdos como das famílias e estou feliz por dar trabalho e dinheiro a pessoas (...) Isto nos dias que corre é um orgulho para mim e se eu conseguir a sustentabilidade financeira disto e acho que vou conseguir, neste momento conseguimos pagar as contas não é, consolidar isto, só pode crescer" (ES3)

"Quando avaliamos o nosso percurso, percebemos que as pessoas desde que vieram para cá deixaram de ser hospitalizadas. É isso que procuramos portanto é a minha satisfação (...) Acho que refletindo sobre sete anos de trabalho aquilo que conseguimos fazer é um sucesso estonteante" (ES9)

Para os restantes empreendedores sociais, cerca de $38 \%$, a noção de ser bemsucedido ainda não foi alcançada por considerarem que ainda precisam de fazer mais para 
se sentirem bem-sucedidos, embora grande parte considere que o seu percurso esteja a ser positivo e seja um meio para alcançar esse sucesso.

"Não, ou seja, não atingi nem metade do que queria atingir na minha vida, nem um terço. Acho que estou no caminho certo para conseguir aquilo que quero" (ES8)

"Acho que para eu ser bem-sucedido ainda preciso fazer muito mais mas isso tem a ver com o meu grau de exigência" (ES13)

\subsubsection{Competências e capacidades do empreendedor social}

No sentido de explorar a confiança que os empreendedores sociais entrevistados têm nas suas próprias competências, a questão de quais devem ser as competências e capacidades de um empreendedor social para obter sucesso e como é que a pessoa as adquiriu, foi também objeto de estudo. Surgiram diversas características que, na verdade, foram apontadas na revisão da literatura como sendo caracterizadoras do empreendedor social. Algumas que mais se destacaram foram a resiliência, a capacidade de liderança, a empatia e ter paixão no trabalho que se faz. Assim, parece que a motivação é um dos elementos fundamentais na prossecução deste tipo de projetos. Uma síntese dos principais requisitos necessários apontados pelos inquiridos e respetivas percentagens, apresentam-se compilados na tabela 12, demonstradas nos seus depoimentos.

\begin{tabular}{|c|l|c|}
\hline $\begin{array}{c}\text { Competências } \\
\text { para obter } \\
\text { sucesso }\end{array}$ & \multicolumn{1}{|c|}{ Depoimento } & $\%$ \\
\hline $\begin{array}{c}\text { Resiliência/pers } \\
\text { istência }\end{array}$ & $\begin{array}{l}\text { "Ter muita persistência, resistência e principalmente muita resiliência } \\
\text { (...) tem que ter paixão pelo que quer fazer e depois tem que ter }\end{array}$ & \\
& $\begin{array}{l}\text { "A persistência...é um elemento fundamental, porquê? Porque um } \\
\text { ganho aqui no projeto pode ser a pessoa começar a tomar banho (...) } \\
\text { (ESI1) }\end{array}$ & 30 \\
\hline
\end{tabular}




\begin{tabular}{|c|c|c|}
\hline Empatia & $\begin{array}{l}\text { "Eu acho que há } 360 \text { maneiras de ver a mesma coisa. A primeira coisa } \\
\text { que um empreendedor social tem de fazer é sair da sua bolha e ver as } \\
\text { outras todas e só assim vais perceber o que na realidade é necessidade } \\
\text { dos outros" (ESI) }\end{array}$ & 30 \\
\hline $\begin{array}{l}\text { Capacidade de } \\
\text { liderança/visão }\end{array}$ & $\begin{array}{l}\text { "Fazer com que os outros acreditem em nós e façam da nossa visão } \\
\text { também a deles e se crie uma visão coletiva desse projeto e pronto, eu } \\
\text { acho que quando isso acontece, a chave do sucesso está garantida" } \\
\text { (ES2) } \\
\text { "Ser um líder de si próprio e para os outros. Para poder trabalhar com } \\
\text { questões sociais tem de ter características de lider e inspiração (...)" } \\
\text { (ES10) }\end{array}$ & 20 \\
\hline $\begin{array}{l}\text { Paixão pelo } \\
\text { trabalho }\end{array}$ & $\begin{array}{l}\text { Gosto por aquilo que está a fazer (ES4) } \\
\text { "A motivação e gostar mesmo daquilo que se está a fazer" (ES7) }\end{array}$ & 10 \\
\hline $\begin{array}{l}\text { Vontade de } \\
\text { aprender }\end{array}$ & $\begin{array}{l}\text { E o que acho também muito importante em qualquer empreendedor, a } \\
\text { vontade de aprender, que é quando nos metemos numa iniciativa, por } \\
\text { algum motivo, experiencia pessoal, para além disso acho que as pessoas } \\
\text { devem aprender tudo sobre aquilo, estar disponíveis para aprender tudo } \\
\text { (ES3) }\end{array}$ & 5 \\
\hline $\begin{array}{l}\text { Experiência } \\
\text { profissional }\end{array}$ & $\begin{array}{l}\text { "Acho que é necessário ter alguma experiencia profissional para se ser } \\
\text { capaz de criar depois o seu próprio projeto. Não digo que tinha que ter } \\
\text { dez ou vinte anos de experiência, mas acho que é preciso algum contato, } \\
\text { para se perceber o que é que se faz bem, o que é que se faz mal”(ES7) }\end{array}$ & 5 \\
\hline Disponibilidade & $\begin{array}{l}\text { "Disponibilidade de tempo sem dúvida "(ES7) } \\
\text { "Primeiro que tudo, sejam cientes da vontade e disponibilidade que } \\
\text { tenham (...)Por isso, um empreendedor social tem de querer. Eu quero } \\
\text { fazer isto" (ES9) }\end{array}$ & 5 \\
\hline $\begin{array}{l}\text { Capacidade de } \\
\text { inovação/difere } \\
\text { nciação }\end{array}$ & $\begin{array}{l}\text { "É necessário termos algum fator diferenciador e estar constantemente } \\
\text { a tentar inovar porque rapidamente o mercado acaba por exigir. Porque } \\
\text { há outras pessoas também criativas e inovadoras e que podem fazer } \\
\text { melhor, portanto nós temos que estar constantemente a atualizar." } \\
\text { (ES7) }\end{array}$ & 5 \\
\hline
\end{tabular}

Tabela 12 - Perceção dos entrevistados das competências necessárias ao empreendedor social para obter sucesso 
Todos os entrevistados consideram que a aquisição destas competências foi feita através da experiência, quer a nível pessoal, profissional ou de formação académica. Consideram que é uma aprendizagem que acontece com o crescimento pessoal e com a própria experiência que foram adquirindo. No presente é algo que vão adquirindo e aprendendo com o próprio projeto e que o facto de terem essas competências é positivo para o próprio projeto.

"Adquiri ao longo da minha experiência enquanto pessoa. Eu acho que são competências que nós adquirimos á medida que vamos construindo o nosso caminho, e também depende muito das nossas opções que fazemos á volta do nosso caminho” (ES7)

"Uma intervenção cientificamente informada e formada, eu trabalho assim porque sou assistente social. Acredito que se fosse uma voluntária não teria seguido este caminho, se fosse uma voluntária sem a preparação que eu tenho do ponto de vista da formação, trabalharia se calhar doutra maneira" (ES11)

"Estou a aprender, todos os dias, em cada local. Aprender a inspirar os outros e a nós mesmos, estar atentos, estar nesse borbulho ativo que é a vida, agarrar oportunidades” (ES10)

Um dos entrevistados, apesar de não ter referido anteriormente a necessidade de um empreendedor social ter competências de gestão, após ter refletido sobre as suas próprias competências, conclui que sente que é necessário para si próprio obter estas ferramentas na área da gestão, no sentido de ter mais conhecimento de como garantir a sustentabilidade do seu projeto.

"O que tenho de fazer em mim é ganhar competências na área da gestão, obter uma visão mais comercial, ganhar mais dinheiro e vai ter que ser essa a principal preocupação nos próximos dois anos “(ES3) 


\subsection{Representações}

O estudo das representações ou perceções que os entrevistados possuem sobre o empreendedorismo social e o empreendedorismo empresarial e de si próprios enquanto empreendedores sociais completa a investigação com importantes contributos no sentido de se compreenderem as suas motivações e constituiu, desta forma, outro dos objetivos deste estudo.

\subsubsection{Diferenças entre empreendedorismo social e empreendedorismo comercial}

A maioria dos entrevistados considera que existem diferenças entre os dois tipos de empreendedorismo, destacando-se a criação de valor social ao invés da geração de lucros, ainda que esta possa ser também uma preocupação na sustentabilidade do projeto. Reforçam também a diferença que existe no trabalho com as pessoas, que implica obviamente um impacto distinto e um esforço e tempo diferente de trabalhar noutro tipo de projetos.

“A única diferença são os resultados...o resultado do ponto de vista da aplicação e o resultado do ponto de vista da missão. Da aplicação que é a aplicação dos lucros e mais-valias em que o empreendedor social investe novamente na organização e daí a economia social estar tão em voga, enquanto que o empresário não investe na totalidade digamos assim. Depois é a questão da missão...enquanto o empresário tem uma missão que é atingir sozinho um determinado patamar, o empreendedor social pretende atingir o topo da pirâmide acompanhado por muita gente” (ES5)

Um dado interessante apontado por um dos empreendedores sociais é o facto de ele achar que os empreendedores sociais falam sempre na primeira pessoa do plural, ao passo que o empreendedor comercial fala na primeira pessoa do singular e, na verdade, ao longo das entrevistas isso foi notável nas palavras dos inquiridos. Parece existir, em boa medida, um sentimento de identificação e de pertença dos entrevistados com a noção de empreendedor social. 
"Enquanto que o Empreendedor social fala sempre na primeira pessoa do plural, o nosso, o empresarial fala no meu” (ES5)

“Ah, existem, sem dúvida (...) não há grandes hierarquias, nós trabalhamos, eu e a Sandra ${ }^{9}$, nenhuma coordena, coordenamos as duas (...) As pessoas que trabalham connosco, que são colaboradoras têm o mesmo poder que nós temos(...) Portanto não há aquela rigidez a nível de autoridade e a nivel de forças de poder(...)Depois também tem a questão efetivamente, não estamos aqui para gerar lucro, não é? (...)Trabalhar com pessoas é muito diferente de trabalhar na área comercial (...)Porque no empreendedorismo social a gente lança um produto, se o produto tem muito sucesso aquilo escoa e OK, e segue. No empreendedorismo social as coisas não são assim, demora muito tempo, trabalha-se com pessoas, como eu disse, eu acho que esta questão das pessoas e dos indivíduos tem um impacto muito grande nos projetos” (ES7)

"Logo no primeiro ponto que é, nós nunca temos em vista o lucro. Nós precisamos sempre de financiamento ou seja, nós nunca conseguimos construir assim um plano de negócios, ter assim uma visão sustentada a longo prazo, porque nós estamos sempre dependentes de alguma ajuda exterior (...)" (ES12)

No seio destas representações, destacam-se ainda alguns elementos que consideram que existem diferenças entre o empreendedorismo social e o empreendedorismo comercial mas que veem os dois fenómenos como algo que se complementa e que um não pode existir sem o outro já que ambos contribuem para cada um deles. Ou seja, o empreendedor social tem um foco social mas deve procurar também o foco financeiro no sentido de garantir a sustentabilidade do projeto e o empreendedor comercial, mais focado na geração de lucro, deve também procurar dar resposta às questões sociais porque isso lhe poderá trazer benefícios pessoais e para a empresa.

“Existem muitas diferenças entre as pessoas, não é? Há pessoas que procuram o lucro exclusivamente. Há pessoas que fazem as coisas porque querem mudar o mundo. Há pessoas que querem ter impacto na vida. Mas isso independentemente da área, há pessoas que estão no empreendedorismo comercial, mas o objetivo é mudar o mundo. O Facebook mudou o mundo e o

\footnotetext{
${ }^{9}$ Nome fictício.
} 
Mark Zuckerberg hoje tem uma fortuna de 20 mil milhões de dólares. Muitas vezes as grandes empresas não começam necessariamente com a procura de lucro, começam porque a pessoa tem uma ideia, acha que vai ter impacto, acha que vai resolver um problema e portanto, o objetivo é sempre mudar o mundo, mas é muitas vezes mudar o mundo e ter esse impacto” (ES8)

"Existe uma tendência atual que eu acho muito interessante, enquanto que aqui há uns anos essa distinção entre empreendedor comercial e social era uma distinção separatista, no sentido de criar uma clivagem entre um e outro, hoje a tendência que se verifica é ao contrário, é uma tendência de partilha de valor no sentido da convergência entre o empreendedorismo comercial e o social e cada um deles vê que pode gerar valor um para o outro ou seja, os empreendedores comerciais perceberem que podem continuar a gerar lucro criando mais impacto social e os empreendedores sociais perceberam que a criação de receita pode ser uma forma de sustentabilizar o seu impacto social. E esta convergência que é chamada partilha de valor é o que está a criar os pilares da nova economia social" (ES13)

\subsubsection{Representação de si próprio: Criatividade e inovação}

A perceção dos entrevistados face a si próprios enquanto empreendedores sociais permite-nos explorar por um lado as representações que têm de si próprios e, por outro lado, conhecer algumas características do empreendedor social.

70\% dos entrevistados considera-se criativo e inovador, características já apontadas na literatura como sendo distintivas do empreendedor social, pelo facto de se tentarem diferenciar, procurarem novas soluções para o seu projeto e para obterem financiamento, por terem constantemente novas ideias e encontrarem recursos que ninguém tinha pensado, e isto é visto como sendo fundamental.

"Sou, claramente. Estou sempre a criar e inovar e não é só [no projeto]. Tenho uma predisposição mental se quiseres, de personalidade para estar sempre a tentar criar soluções novas e por isso sim, considero-me uma pessoa iminentemente criadora e inovadora e acho que é um ponto diferenciador em qualquer projeto, num projeto social ainda mais mais porque na realidade o que nós procuramos é arranjar soluções alternativas àquelas que já existem a um custo muito mais baixo ou com um grau de eficácia muito mais alto ou ambos, recorrendo a recursos que 
normalmente as pessoas não pensam. Nós pensamos em recursos que mais ninguém pensa e para isto é preciso manter uma chama de criatividade altamente aberta por isso sim, considero-me altamente criado" (ES13).

Os restantes $\mathbf{3 0 \%}$ dos entrevistados não se consideram criativos nem inovadores ou referem apenas uma das características, não havendo grande identificação com esta questão.

"Acho que não. Criativa e inovadora...acho que criativos são os artistas. Eu tento ver aquilo que é preciso, pelo menos nesta área. Não acho que seja criativa nem inovadora" (ES4)

"Eu acho que se calhar inovador, porque o mundo hoje já nada se cria, está tudo se cria, apenas se ajusta, aí sim posso achar que a nível de adaptação ao que existe e às novas dificuldades, ai posso-me considerar inovador e não criador" (ES5)

\subsubsection{Aspetos positivos e negativos de ser um empreendedor social}

Os aspetos positivos de ser um empreendedor social estão muito associados, nas palavras dos entrevistados, ao impacto social que criam. Os negativos estão mais relacionados com as dificuldades encontradas durante o processo e a gestão do tempo, já que referem falta de tempo para trabalhar nos projetos ou timings muito apertados para concretização dos mesmos. Os aspetos positivos e negativos apontados pelos empreendedores sociais apresentam-se compilados na tabela 13, tendo entre parêntesis a frequência, isto é o número de vezes que foram referidos pelos entrevistados.

\begin{tabular}{|c|c|}
\hline Aspetos positivos & Aspetos negativos \\
\hline Impacto social (7) & As dificuldades encontradas no processo (6) \\
Autonomia (3) & Gestão do tempo (timings) (6) \\
Liberdade de decisão (3) & Incompreensão política e social (5) \\
Mente aberta, pensar de forma diferente (3) & Sentimento de prepotência (3) \\
Realização pessoal (2) & Baixos salários (2) \\
Conhecer pessoas (2) & Não conseguir desligar do projeto (2) \\
Participação ativa do público-alvo (1) & Falta de reconhecimento (2) \\
\hline
\end{tabular}


Capacidade de inovação (1)

Tabela 13 - Aspetos positivos e negativos de ser um empreendedor social

\subsection{Aprendizagens}

\subsubsection{Recomendações a potenciais empreendedores sociais}

As recomendações que os entrevistados dariam a um potencial empreendedor social demonstram as aprendizagens que retiraram do seu processo e a motivação que sentem para continuar no projeto. Uma das que mais se destaca é a criação de redes de pessoas, que permitirão alcançar novas parcerias, novos contactos e, dessa forma, diferentes formas de atuar e novas oportunidades. Reforçam a ideia de ser persistente, uma das características do empreendedor social já referida anteriormente, e de acreditar na mudança e na realização dos seus sonhos, ainda que, com ideias realistas que vão ao encontro das verdadeiras necessidades das pessoas. Para uma melhor compreensão destas recomendações, elas foram agrupadas na tabela 14, juntamente com alguns depoimentos das entrevistas e respetiva percentagem de respostas.

\begin{tabular}{|c|c|c|}
\hline Recomendações & Depoimentos & $\%$ \\
\hline $\begin{array}{l}\text { Redes de } \\
\text { contactos, } \\
\text { networking }\end{array}$ & $\begin{array}{l}\text { "Para mim eu acho que é ...trabalho, redes, as pessoas não dão valor } \\
\text { nenhuma networking, a participarem em redes nacionais e } \\
\text { internacionais mas é a partir daí que obtém conhecimentos, surgem } \\
\text { oportunidades, aprendizagem e crescimento e em Portugal as pessoas } \\
\text { não percebem o valor das redes" (ES8) } \\
\text { "Eu costumo dizer que o truque para qualquer projeto é pessoas, } \\
\text { pessoas e mais pessoas, e a tua capacidade de te relacionares, } \\
\text { identificares recursos e fazeres pontes entre as pessoas e conseguires } \\
\text { pôr isso em movimento a favor do interesse que tu queres gerar" } \\
\text { (ES13) }\end{array}$ & 30 \\
\hline Ser persistente & $\begin{array}{l}\text { "Ser persistente...quando temos um sonho e acreditamos que ele é } \\
\text { bom e vai gerar mudança, temos de testá-lo, verificar e se ele se } \\
\text { mantém vivo e com força ser persistentes" (ES10) }\end{array}$ & 30 \\
\hline Acreditar na & "É assim, eu acho que acima de tudo uma atitude muito positiva e & 20 \\
\hline
\end{tabular}




\begin{tabular}{|c|c|c|}
\hline mudança & $\begin{array}{l}\text { uma atitude de que é possivel acreditar na mudança (...)Agora, } \\
\text { lamentar-nos e continuarmos a achar que não há nada a fazer, para } \\
\text { mim não é o caminho, e acho que não é a postura de nenhum } \\
\text { empreendedor (...)" (ES7) } \\
\text { "Seguir para a frente e não se deixarem desmotivar pelas } \\
\text { adversidades que podem surgir nesse caminho, porque no fim o fruto é } \\
\text { muito gratificante, de todo o nosso tempo e investimento pessoal" } \\
\text { (ES12) }\end{array}$ & \\
\hline $\begin{array}{l}\text { Ter paixão pelo } \\
\text { trabalho }\end{array}$ & "Gostar do que vai fazer. Gostar, sem dúvida" (ES4) & 10 \\
\hline $\begin{array}{l}\text { Ser sonhador mas } \\
\text { realista }\end{array}$ & $\begin{array}{l}\text { "Eu acho que o truque é nós juntarmos, usando uma metáfora, } \\
\text { conseguir juntar o céu e a terra ou seja, trazer elementos de realismo } \\
\text { àqueles que são os nossos sonhos, as nossas ambições, sim senhor ser } \\
\text { sonhador, acreditar nos sonhos, ter visão, mas com os pés na terra e } \\
\text { jogando com o que se tem" (ES13) }\end{array}$ & 10 \\
\hline
\end{tabular}

Tabela 14 - Recomendações dos entrevistados a um potencial empreendedor social

\subsubsection{Mudanças na vida dos empreendedores sociais}

Face à questão colocada “o que mudou em si?”, cujo objetivo era explorar o que tem representado para a pessoa ser um empreendedor social, as respostas dos entrevistados remetem-nos para questões de crescimento a nível pessoal e profissional, mudança na forma como os empreendedores sociais veem o mundo e as pessoas com quem trabalham e a vontade de continuar a lutar pelos seus objetivos e pelo trabalho que têm vindo a desenvolver. As mudanças referidas pelos empreendedores sociais encontram-se representadas na tabela 15 , juntamente com os seus depoimentos.

\begin{tabular}{|c|l|c|}
\hline Mudanças & \multicolumn{1}{|c|}{ Depoimentos } & $\%$ \\
\hline $\begin{array}{c}\text { Respeito pelo } \\
\text { outro e } \\
\text { acreditar no } \\
\text { outro }\end{array}$ & $\begin{array}{l}\text { "um respeito enorme pelas pessoas (...) São os meus heróis. Um desprezo } \\
\text { profundo pelas pessoas que abusam do poder e com isso impedem estas } \\
\text { pessom aquilo que são, que têm potencial para ser" (ES9) }\end{array}$ & \\
& $\begin{array}{l}\text { "Mapacidade humana de transcender e ultrapassar os obstáculos e limites" } \\
\text { (ESI3) }\end{array}$ & 28 \\
\hline
\end{tabular}




\begin{tabular}{|c|c|c|}
\hline $\begin{array}{l}\text { Ter uma nova } \\
\text { visão }\end{array}$ & $\begin{array}{l}\text { "Hum...experiência...eu acho que ter uma visão, acho que foi muito } \\
\text { enriquecedor" (ES3) } \\
\text { "Mudou a minha visão de ver o mundo" (ES5) } \\
\text { "Se calhar fiquei mais sensivel para as carências dos outros, porque eu } \\
\text { neste momento consigo ter uma boa ideia da quantidade de carências que } \\
\text { existem em diferentes partes da sociedade que antes não tinha(...) mudou } \\
\text { a minha visão (ES12) }\end{array}$ & 28 \\
\hline $\begin{array}{c}\text { Crescimento } \\
\text { pessoal }\end{array}$ & $\begin{array}{l}\text { "Foi...o perceber que...quando mais crescemos, menos sabemos e isso é } \\
\text { bem verdade e mais duvidas temos sobre a nossa existência, a sociedade, } \\
\text { o que é o mundo" (ES2) }\end{array}$ & 14 \\
\hline $\begin{array}{l}\text { Vontade de } \\
\text { continuar a } \\
\text { trabalhar e } \\
\quad \text { lutar }\end{array}$ & $\begin{array}{l}\text { "Eu acho que o que mudou mais em mim foi efetivamente a minha atitude } \\
\text { positiva e esta força de querer continuar a andar para a frente apesar de } \\
\text { tudo á minha volta parecer que está mais em baixo (...) nem que seja eu a } \\
\text { acreditar nesta ilusão de que as coisas podem melhorar ou que as coisas } \\
\text { podem mudar, que me fazem mover" (ES7) }\end{array}$ & 14 \\
\hline $\begin{array}{l}\text { Conhecer } \\
\text { pessoas e } \\
\text { aprender com } \\
\text { as mesmas }\end{array}$ & $\begin{array}{l}\text { "(...) foi conhecer tanta tanta gente, imensas histórias de vida e com elas } \\
\text { aprendi muito porque cada pessoa ensina-nos sempre coisas" (ES2) } \\
\text { "Acho que o que foi mais enriquecedor foi as pessoas fantásticas que se } \\
\text { cruzaram no meu caminho" (ES3) }\end{array}$ & 7 \\
\hline $\begin{array}{l}\text { Aprender a } \\
\text { defender uma } \\
\text { causa }\end{array}$ & $\begin{array}{l}\text { "O que mudou em mim? Nunca tinha pensado nisso... este projeto em } \\
\text { mim... há uma coisa por exemplo que falei noutro dia que é, fiquei a } \\
\text { saber melhor o que é defender melhor uma causa, certo?" (ES11) }\end{array}$ & 7 \\
\hline
\end{tabular}

Tabela 15 - Mudanças nos entrevistados enquanto empreendedores sociais

\subsection{Desistência do projeto}

\subsubsection{Motivos para desistir do projeto}

$\mathrm{Na}$ procura das razões que poderiam levar os entrevistados a desistir do seu empreendimento, foram encontrados cinco tipos de motivos, sendo que os primeiros dois foram os que mais se destacaram: pessoais (motivos familiares ou de doença), criação de novos projetos, financeiros, migração e o próprio projeto terminar. Na tabela 16 podemos ver quais as razões mais mencionadas, através da percentagem de empreendedores sociais 
que as referiram. Podemos afirmar que à exceção da criação de novos projetos, que demonstra uma vontade positiva de continuar a criar e inovar, as outras, com conotação mais negativa, mostram que apenas razões com carácter forte, como problema de saúde ou de família ou razões financeiras, é que fariam o empreendedor social desistir.

\begin{tabular}{|c|c|c|}
\hline $\begin{array}{c}\text { Motivos } \\
\text { para desistir }\end{array}$ & Depoimento & $\%$ \\
\hline $\begin{array}{l}\text { Razões de } \\
\text { índole } \\
\text { pessoal } \\
\text { (doença, } \\
\text { família) }\end{array}$ & $\begin{array}{l}\text { "Problema de saúde ou família porque dificilmente ele vai parar e } \\
\text { naturalmente vou-me afastar dele" (ES1 } \\
\text { "E depois constrangimentos da vida, desde um acidente simples, a } \\
\text { ocorrência de outras motivações da história de vida" (ES10) }\end{array}$ & 35 \\
\hline $\begin{array}{l}\text { Criação de } \\
\text { novos } \\
\text { projetos }\end{array}$ & $\begin{array}{l}\text { "Um projeto novo. Se eu entretanto me lembrar de alguma coisa } \\
\text { que queira fazer e adore... porque eu sou daquelas pessoas que } \\
\text { adora criar projetos" (ES8) } \\
\text { "(...) Tenho de ir criar outros projetos inovadores em áreas que eu } \\
\text { sinta que não estão trabalhadas" (ES5) }\end{array}$ & 35 \\
\hline $\begin{array}{l}\text { Razões de } \\
\text { índole } \\
\text { financeira }\end{array}$ & $\begin{array}{l}\text { "Zero agora na conta. Não ter dinheiro para pagar a quem... não } \\
\text { ter recursos para continuar a fazer. Não é o não dormir, é o não } \\
\text { ter mesmo recursos para continuar" (ES4) }\end{array}$ & 14 \\
\hline Migração & "No projeto o único motivo era se eu emigrasse" (ES6) & 7 \\
\hline $\begin{array}{l}\text { Término do } \\
\text { projeto }\end{array}$ & $\begin{array}{l}\text { "Não sei porque é um projeto e os projetos podem } \\
\text { acabar..."(ES13) }\end{array}$ & 7 \\
\hline
\end{tabular}

Tabela 16 - Motivos para desistir do empreendimento social

Dos entrevistados, dois elementos responderam que não desistiriam do projeto no presente, contornando a questão de forma mais positiva e não fazendo referência aos motivos já referenciados. Contudo, pode não lhes ter ocorrido esses motivos e terem apenas pensado a questão de forma mais positiva, já que afirmam que nada os poderia fazer desistir 
pois é algo que faz parte do seu percurso e que fazem questão que assim continue a ser, como se vê num dos depoimentos.

"Neste momento não há nada que me impeça de abandonar um projeto. Posso dizer que muitas das vezes as minhas opções profissionais e as minhas opções pessoais dependem muito do [projeto]. Não abdico de determinadas coisas porque se cheguei até aqui não vou recuar e não vou desistir” (ES7)

\subsection{Motivações}

\subsubsection{Motivações na criação do empreendimento social}

O principal objetivo desta investigação foi conhecer e explorar as motivações dos empreendedores sociais na criação e desenvolvimento do seu projeto. Diversos tipos de motivações foram encontrados. No sentido de facilitar a leitura e sintetizar ideias, os resultados são apresentados na tabela 17 , sendo que a forma como se chegou aos mesmos é discutida em seguida.

\begin{tabular}{|c|c|c|}
\hline \multicolumn{2}{|r|}{ Motivações dos empreendedores sociais } & $\%$ \\
\hline $\begin{array}{l}\text { Altruísmo } \\
\text { (pull) }\end{array}$ & $\begin{array}{l}\text { Vontade de trabalhar para bem e benefício dos outros constitui um } \\
\text { fator de motivação }\end{array}$ & 92 \\
\hline Paixão (pull) & $\begin{array}{l}\text { O interesse e a vontade pessoal de ingressar no empreendedorismo } \\
\text { social, gosto pelo trabalho realizado, pela área e pelas pessoas foi } \\
\text { também um fator motivacional }\end{array}$ & 61 \\
\hline $\begin{array}{l}\text { Influência de } \\
\text { role models }\end{array}$ & $\begin{array}{l}\text { O facto de os empreendedores sociais terem alguém próximo } \\
\text { envolvido neste tipo de iniciativas, constitui uma influência para } \\
\text { ingressar no empreendedorismo }\end{array}$ & 58 \\
\hline Voluntariado & $\begin{array}{l}\text { O facto dos empreendedores sociais terem feito voluntariado foi um } \\
\text { dos fatores que motivou a ser empreendedor social }\end{array}$ & 53 \\
\hline $\begin{array}{l}\text { Inovar e criar } \\
\quad(\text { pull })\end{array}$ & $\begin{array}{l}\text { A vontade de inovar e de criar projetos é um fator de motivação } \\
\text { para criar o empreendimento social }\end{array}$ & 23 \\
\hline
\end{tabular}




\begin{tabular}{|c|l|c|}
\hline $\begin{array}{c}\text { Oportunidade } \\
(\text { pull })\end{array}$ & $\begin{array}{l}\text { A criação do empreendimento adveio de uma oportunidade que } \\
\text { surgiu na vida do empreendedor }\end{array}$ & 23 \\
\hline $\begin{array}{c}\text { Fatores } \\
\text { relacionados }\end{array}$ & $\begin{array}{l}\text { A criação do empreendimento deve-se a dois fatores: à necessidade } \\
\text { de criação de emprego e à desilusão e insatisfação com empregos } \\
\text { anteriores }\end{array}$ & 7 \\
$\begin{array}{c}\text { com o } \\
(\text { push })\end{array}$ & & \\
\hline
\end{tabular}

Tabela 17 - Motivações dos empreendedores sociais na criação do empreendimento social

\section{Altruísmo (fator pull)}

O altruísmo foi a motivação mais mencionada, por $92 \%$ dos entrevistados, como sendo a vontade de trabalhar em prol do bem-estar da sociedade e a preocupação em fazer os outros felizes. Na verdade, esta motivação sempre pareceu ser óbvia, se tivermos em conta que a revisão da literatura apontava como característica dos empreendedores sociais o facto de eles serem pessoas altruístas. Por outro lado, existem, como veremos à frente, razões menos altruístas; contudo, esta foi a mais mencionada e aquela que parece realmente ter movido os entrevistados na criação do seu empreendimento, como podemos ver em alguns dos seus depoimentos:

"Poder fazer uma coisa para os outros e não para nós, eu quero que os outros beneficiem, porque se o outro estiver bem, eu naturalmente vou estar bem” (ES1)

"É mesmo a gratificação que tiramos de ver os outros felizes ou mais felizes, e conseguirmos extrair muito potencial de pessoas que acham que não o têm” (ES12)

No mesmo sentido, os entrevistados $n^{\circ} 2$ e $n^{\circ} 3$ complementam esta ideia acrescentando ainda que a questão financeira não é uma prioridade: 
“Eu não posso fazer as coisas só para ganhar dinheiro, tenho que fazer as coisas porque sei que me dão prazer e que estou a lutar por um mundo melhor, por um mundo onde as pessoas são mais pessoas e menos objetos" (ES2)

"Não queria, não ia começar algo para ficar rica, não era o meu objetivo. Eu queria era fazer algo para ajudar os miúdos e as famílias, isso fazia sentido para mim na minha vida" (ES3)

Nesta noção de altruísmo podemos ainda ver um certo idealismo e crença de que é possível "mudar o mundo", por isso está implícita uma vontade de lutar por uma sociedade mais justa e igualitária:

"É o facto de acreditar que ajudar a desenvolver as capacidades e autonomia das pessoas, podemos fazer algo melhor, é um bocadinho aquilo de acreditar que podemos mudar o mundo" (ES7)

\section{Paixão (fator pull)}

Este fator, também mencionado na literatura nas categorias das motivações no empreendedorismo comercial, está associado ao gosto pelo trabalho em si e um prazer inerente na área e no trabalho efetuado. É um tipo de motivação intrínseca e como já foi referido no capítulo II, diz respeito a um interesse pessoal na tarefa empreendedora (Carsrud \& Brannback, 2011), tendo sido mencionado por $61 \%$ dos entrevistados. Nas suas palavras, a criação do empreendimento não teve por base uma necessidade, mas sim uma vontade inerente a uma paixão, sendo algo que faz mover a pessoa, atraindo-a para uma área do seu interesse e sendo, por isso, considerada uma motivação do tipo pull.

"Não foi aquela ideia de [preciso de] ou tenho [necessidade de], foi a [ vontade de] (...) era a área que eu gostava (...) era algo que estava a fazer sozinho enquanto me desse prazer" (ES1) 
"Isto de ter o próprio emprego, eu não tenho necessidade de ter uma coisa minha, eu tenho necessidade de trabalhar numa coisa que acredito (...) Eu acho que é o gosto pela área, o gosto pelo trabalho que estou a fazer, a mim dá-me imenso gozo, dá-me imenso gozo” (ES4)

\section{Influência de role models}

O facto de os entrevistados terem alguém próximo envolvido em processos de empreendedorismo parece ter influência no seu envolvimento, já que mais de metade dos entrevistados $(58 \%)$ referem ter sido influenciados por outros empreendedores, desde familiares, amigos ou grupo de pares, tal como podemos ver em alguns dos seus depoimentos.

"O meu pai, a minha mãe...claro que sim, somos todos empreendedores. Eu acho que é uma questão que faz parte do meu código genético, da minha educação...(...) , a minha mãe começou a trabalhar aos 42 anos como empreendedora (...) o meu irmão é empresário de sucesso que ganhou vários prémios não só em Portugal como em outros países” (ES6)

“A minha família em si e muitos amigos, uma das pessoas que considero mais fabulosa (...) foi ela que criou grande parte do projeto (...); ser amigo dela e partilhar muitas questões sociais foi inspirador e influenciou de certeza" (ES10)

\section{Voluntariado}

O voluntariado, associado aos valores que a pessoa tem e ao sentimento de utilidade, foi também um dos motivos mais mencionados por 53\% dos entrevistados como tendo tido influência na sua motivação. A experiência que tiveram anteriormente, quer na área do projeto, quer noutras, ajudou-os a pensar também na área e no projeto que poderiam desenvolver posteriormente.

"Fiz, fiz. Nesta área e na área social. Não nesta área específica. Já sou voluntaria desde os 14 anos de idade (...)Sim, isso sem dúvida. Isso sem dúvida que influenciou, pela questão que eu disse, pelo facto de haver necessidade de nós estarmos em experiências e em contacto com outras 
instituições, outras redes, para também percebermos o que é que gostamos, o que é que queremos fazer e em que modelo é que o pretendemos fazer" (ES7)

“O voluntariado já vem de alguns tempos (...) influenciou no crescimento em dar algo em prol dos outros sem ser recercido economicamente (...) conhecer outras realidades do ser humano e efetivamente muitas destas regras de ligação entre as pessoas aprendi aí no voluntariado" (ES10)

\section{Inovar e criar (fator pull)}

A vontade que o indivíduo tem de criar novos projetos ou de inovar num já existente se diferenciar foi uma motivação que já apareceu nas motivações no empreendedorismo comercial e tem também algum relevo no empreendedorismo social, o que faz sentido se virmos $70 \%$ dos entrevistados se consideram inovadores e criadores. Ainda que esta motivação tenha surgido nas palavras de alguns empreendedores sociais, ela não é tão representativa como as anteriores, tendo sido mencionada por $23 \%$ das pessoas, sendo que para o empreendedor social $n^{\circ} 8$ foi a motivação mais determinante na criação do empreendimento.

“A minha motivação empreendedora veio do facto de eu gostar de criar coisas, gostar de criar projetos (...) acima de tudo para mim, pessoalmente, é mesmo esta vontade de criar coisas, criar projetos" (ES8)

\section{Oportunidade (fator pull)}

O reconhecimento de uma oportunidade foi outra motivação que surgiu no decurso das entrevistas, tendo sido mencionada por $23 \%$ dos inquiridos. Esta noção de oportunidade remete-nos mesmo para o sentido da palavra, já que surgiram oportunidades na vida destes elementos que os fizeram agarrá-la, não motivados por algum tipo de recompensa externa, mas sim por uma vontade interna de fazer algo com sentido na sua vida. Dois deles foram motivados por um concurso que procurava que dessem ideias e tendo a ideia sido selecionada, decidiram avançar, tal como se lê nas palavras do empreendedore $\mathrm{n}^{\circ} 3$ : 
"Achei mesmo que tinha de fazer isto, era uma oportunidade de algo que para mim fazia sentido e achava que tendo ganho o concurso (...) eu senti que tinha que inventar condições para isso acontecer" (ES3)

O empreendedor social $\mathrm{n}^{\circ} 13$ fez referência à oportunidade, na medida em que esteve "atento aos sinais que apareceram no caminho" (ES13) e procurou seguir essa oportunidade tendo sempre " um certo idealismo no sentido em que sempre acreditei que tinha uma missão e um sonho de significado para a minha vida e que era capaz de o concretizar" (ES13).

\section{Fatores relacionados com o trabalho (fator push)}

Para o empreendedor social $n^{\circ} 13$, a sua motivação adveio não só do reconhecimento de uma oportunidade, mas surgiu também a questão da insatisfação com os empregos anteriores, tendo sido o único empreendedor social que referiu esta categoria. Assim, e tal como foi referido na literatura, podemos afirmar que os empreendedores podem ser motivados simultaneamente por fatores push e fatores pull. Este empreendedor teve uma série de empregos fora da área social, depois criou projetos de empreendedorismo comercial e percebeu que não estava satisfeito, pelo contrário desiludido com algumas circunstâncias.

"Esperava trazer justiça ao mundo e quando comecei a ser advogado pensei que ia prender bandidos e rapidamente percebi que não ia prender nenhum, deixei escapar alguns e trabalhei para vários e fiquei um bocado desiludido e deixei direito (...)Fui para o BCP para a área comercial experimentar a experiencia de trabalhar numa grande organização (...)quando cheguei ao fim percebi que não queria nada daquilo e e cheguei ao BCP e disse "vou-me embora"(...) e eu disse "pois, mas eu não estou feliz" e comecei uma série de projetos de empreendedorismo(...)Em 2006, estava eu como diretor de marketing de um grupo de comunicação em Lisboa e a pessoa responsável pelo grupo fez uma grande marosca na empresa e deixou 30 pessoas sem trabalho. Eu na altura aquilo serviu-me como um alerta de introspeção. Costumo dizer que [o projeto] foi um misto de desilusão, oportunidade e idealismo" (ES13) 
Houve ainda um determinado conjunto de motivações que faziam parte da entrevista e que, tendo aparecido na revisão da literatura como sendo motivações para o empreendedorismo, poderiam também ser motivações no empreendedorismo social mas na verdade não constituem motivações para os empreendedores sociais entrevistados. Contudo, eles têm alguma relevância e, por isso, vale a pena explorar agora os quatro tipos de motivações, as quais se designarão de motivações residuais.

\subsubsection{Motivações residuais}

\section{Vontade de ser o próprio chefe}

Para a maioria dos empreendedores sociais entrevistados, embora ser o próprio chefe não seja um fator motivador para criar empreendimento, é algo que por um lado traz vantagens, como sendo a liberdade de decisão, autonomia, trabalhar em algo que se gosta e se acredita. Por outro lado também são apontadas diversas desvantagens por estes mesmos entrevistados, nomeadamente o facto de se ter que decidir sozinho, exigir grandes responsabilidades e tempo, como podemos ver em alguns dos seus depoimentos. Poderá contudo, em alguns casos, ser considerado um fator para continuar a envolver-se em projetos de empreendedorismo.

"É bom porque não tenho propriamente de dar "améns" a ninguém. Por outro lado, implica outras responsabilidades, se alguma coisa corre mal a culpa é minha, é minha e de quem está comigo (...) Mas ao mesmo tempo depois, quando consigo coisas, também fico muito contente” (ES4)

“As grandes decisões, tenho de as decidir, não é fácil. É por isso que sou, continuo a ser, enfermeiro em part-time e dá-me algum equilíbrio porque aí sou mandado e é muito bom chegar lá, fazer o trabalho com os meus doentes e vir-me embora, porque aqui não; aqui muita coisa, tudo funciona, mas muita coisa tenho que decidir (...) Mas também tem um lado bom, ser o meu chefe dá-me a liberdade de poder criar, poder pensar, poder ter a liberdade (...) poder ser pago para poder fazer aquilo que me dá prazer e isso nem toda a gente pode fazer" (ES2) 
Por outro lado, para três empreendedores sociais esta questão tem uma conotagem muito negativa, essencialmente porque se sentem sozinhos no momento de tomada de decisão.

"É doloroso...é um caminho solitário muitas das vezes. Eu costumo fazer a analogia com um veleiro em alto mar, em que estou sozinho e preciso de chegar ao meu porto" (ES5)

“Vejo-me muito só, olhe vejo-me muito só (...) na hora de decidir está-se só. E ás vezes aí até tenho medo, porque não tenho a certeza nunca, apesar de ouvir sugestões, de ser aquele o caminho" (ES11)

\section{Reconhecimento}

Embora a categoria reconhecimento seja apontada como um dos fatores de motivação dos empreendedores comerciais e pudesse ser considerada um dos fatores para iniciar um projeto, já que a teoria de McClleland defende que é um traço dos empreendedores, neste estudo o reconhecimento não é um fator de motivação para criar um projeto de empreendedorismo social. Ainda que, na perceção de todos os entrevistados, o reconhecimento pessoal exista, não foi uma motivação para ingressar nas suas aventuras. Para alguns elementos o reconhecimento é visto como algo muito positivo que contribui para a sua motivação hoje em dia mas que não é uma preocupação.

"Sim, completamente, em termos pessoais trouxe-me muitos reconhecimentos que eu não imaginava alguma vez ter. Em termos sociais, o IES conseguiu ajudar a definir aquilo que somos e podes-te assumir como empreendedor social” (ES10)

"Por um lado sim, porque pronto, eu nunca liguei muito a isso, a verdade é que através [do projeto] conheci um mundo de gente e de coisas que se calhar doutra maneira não conheceria; não tiro muito partido delas" (ES2)

Inclusive, alguns dos entrevistados referem que esse reconhecimento é mais importante na medida em que lhes traz visibilidade ao projeto e não a si próprios. Ainda 
assim, o reconhecimento é importante como uma forma de agradecimento e como uma força para continuar a trabalhar, como podemos ver nas palavras do entrevistado $n^{\circ} 6$ e $n^{\circ} 3$ :

"Sim, neste momento claramente até porque há uma moda em termos de empreendedorismo e inovação social, que é uma moda positiva porque também cria, faz um click em termos de “atenção é preciso ver o que está à nossa volta de outra forma”(...) reconhecimento passa a ser importante porque quando se tem alguma mensagem com algum valor de tornar as pessoas mais conscientes de si próprio (...) O reconhecimento e agradecimento são questões básicas no relacionamento humano. Quem não o faz perde por não fazer porque é sempre multiplicado o esforço anterior, quem recebe agradecimento e reconhecimento, renova com mais energia, é humano" (ES6)

"Eu acho que sim, porque mais na lógica da visibilidade que está a ter o projeto porque eu já me sentia realizada profissionalmente (...) Mas é obvio que sim, no meu caso porquê? Porque tive um IES que me reconheceu, isso é muito motivador, sentir o reconhecimento do trabalho. Mas no meu caso eu não fui por aí, não é por causa disso, ajuda à motivação, ajuda a crescer porque dá visibilidade"(ES3)

\section{Realização pessoal}

A necessidade de realização pessoal é uma das motivações que surgiu na literatura do empreender comercial paralelamente ao reconhecimento e à vontade de ser o próprio chefe. Contudo, neste estudo, a necessidade de realização não é evidente na criação do empreendimento social. Quando questionados acerca desta questão, os entrevistados são mais realizados com o projeto, mas esta não dependeu apenas da concretização do mesmo e não foi com esse intuito de se tornarem mais realizados que criaram o projeto.

"Isso é das coisas que eu desde o início do ano, porque foi nessa altura que eu mudei de trabalho e que se calhar também me permitiu dedicar mais tempo ao projeto, senti que sou extremamente realizada. Porque faço exatamente aquilo que eu gosto. Está dependente da concretização do projeto e de trabalhar na área social que é aquilo que me move todos os dias e o projeto como está inserido naquilo que eu gosto sem dúvida que sim” (ES7) 
"Nós para sermos felizes temos de nos realizar em várias áreas ou em todas, na afetiva, social, financeira, sexualidade, enfim em todas elas. Eu optei por estas, por as minhas, pelo projeto, a junção de todas deu a minha pessoa que é uma pessoa quase feliz" (ES2)

A realização pessoal para uns já existia antes da criação do projeto e para outros foi uma das consequências de terem criado o projeto.

“Acho que no meu caso não. Já estava realizada nas outras áreas, mesmo a nível familiar, com filhas, etc., mas acho que sou muito mais feliz e mais realizada por causa deste projeto" (ES3)

Para três dos entrevistados, a realização ainda não aconteceu no sentido em que sentem que ainda têm de fazer mais.

"Não me sinto realizada...ou seja, sinto que estou cada vez mais perto daquilo que eu quero, sinto-me feliz com o percurso que estou a ter mas não me sinto realizada porque estou longe da realização" (ES8)

\section{Vontade de correr riscos}

Esta categoria motivacional, também mencionada nas categorias das motivações empreendedoras no capítulo II, não constitui um fator de motivação na criação dos empreendimentos sociais deste estudo. Ou seja, embora nove dos entrevistados refira existir risco no seu empreendimento, eles não consideram ter sido uma motivação na criação do projeto, sendo que oito deles afirmam inclusivamente não gostar de correr riscos. Ainda assim, tomaram esses riscos na criação do seu projeto, o que pode demonstrar alguma tendência de propensão ao risco, característica própria de qualquer empreendedor quando sabe que criar um projeto tem obviamente riscos associados.

"Quando nos atiramos para as coisas não pensamos nos riscos, pensamos em todos os sonhos e agarramo-nos a eles e se eu tivesse pensado no risco no início, como sou uma pessoa 
ansiosa, não tinha feito nada... Hoje em dia tenho outros medos, vou gerindo esses medos, sou ansiosa, mas ambivalente, sonhadora” (ES9)

"Sim há um forte risco, de eu perder tudo que tinha. Não gosto nada, acho que ninguém gosta mas está subjacente, há que assumi-lo” (ES3)

$\mathrm{Na}$ opinião dos restantes quatro entrevistados, não existe risco associado ao projeto, pelo contrário, consideram que eles estão a crescer ou a replicarem-se.

“Acho que não há riscos, só há beneficios, eu por acaso acho que não há riscos nenhuns, pelo contrário" (ES11)

"Não, de modo algum, aliás ele está em fase de replicagem" (ES6)

\subsubsection{Alteração nas motivações ao longo do tempo}

Compreender o impacto que a motivação sofre ao longo do tempo foi também um dos objetivos do estudo. Quando colocada esta questão, os entrevistados possuem três diferentes tipos de perceção: a perceção de que as motivações se mantém, de que as motivações são maiores com o crescimento e sucesso do projeto, no sentido em que estão mais motivados, e a perceção de que as motivações são diferentes.

Mais de metade dos entrevistados considera que a sua motivação aumentou com o sucesso do empreendimento e com a experiência adquirida; por um lado, o facto de ainda haver muito trabalho por fazer no projeto e, por outro lado, o facto de verem resultados positivos movem a pessoa para querer fazer cada vez mais, ou seja, parece existir aqui uma relação entre o sucesso e a motivação.

À medida que a perceção que o empreendedor social tem face ao sucesso aumenta, a motivação também é maior, havendo uma vontade de fazer ainda mais. Isto é importante na medida em que quase metade dos entrevistados consideram-se bem-sucedidos, pelo que isso pode ser um bom mote para continuar o seu projeto. 
“É muito maior (...) se tivéssemos a certeza que isto amanhã estava resolvido e não tínhamos de nos preocupar mais, se calhar a motivação era menor porque ela é inversamente proporcional ao desafio; quanto maior o desafio, mais motivado ficas" (ES1)

"A questão do empreendedorismo social era uma palavra que não usava; criar mais valor social não usava; queria criar valor para as pessoas e que estas tivessem mais dinheiro do bolso mas não o exprimia através de indicadores; hoje, com o crescimento do projeto e tentativa de o institucionalizar, requer indicadores de gestão, de impacto, a pensar no projeto de forma pragmática (...)Está mais claro para mim aquilo que me move para trabalhar com as pessoas neste projeto" (ES10)

"O meu principal fator motivador é constatar que por um lado consegui ter um impacto muito grande a um nível mas por outro lado perceber que posso ter um impacto maior a outro nivel" (ES13)

Três entrevistados têm a perceção de que as suas motivações atualmente são as mesmas aquando do início da criação do projeto. No fundo isto representa a mesma vontade de lutar pelos seus objetivos e não significa que a motivação tenha diminuído, mas é notável no seu discurso alguma hesitação e alguma revolta perante determinadas situações.

“A mesma motivação. Hoje sinto a mesma energia...quer dizer, não lhe posso dizer que não fique, não me incomode, uma revolta que sinto quando vejo a utilização perversa dos parcos recursos para fins fictícios (...) revolta-me ver pessoas a ocuparem lugares por interesse próprio e não por amor à causa porque eu tenho tanto amor (...)Hoje continuo com o mesmo desassossego, há um desassossego que foi nascendo e se tornou insuportável e eu não podia estar sem fazer nada. Hoje ainda o sinto..." (ES9)

"São as mesmas, só que hoje eu consigo firmá-las de forma mais sustentada do que quando era mais miúda." (ES11)

Os outros dois elementos têm a perceção de que são diferentes, sendo que um considera que o trabalho que hoje lhe está associado é diferente daquele que começou por 
fazer no projeto e que isso se torna mais desmotivante nesse sentido, embora haja uma clara vontade de se manter no projeto, como se vê no seu depoimento:

“A parte que não trocaria ou vejo diferente é que na altura, uma coisa pequenina, que está a crescer, é fácil controlar, fácil de gerir, fácil de sonhar... agora, o papel passou um bocadinho para, como há pouco dinheiro, pouca gente com vontade de gerir, eu tenho de ser o gestor não é, eu não queria ser o gestor, eu gosto de ser o sonhador, o que vai motivar, o que cria novos projetos, que vai idealizando novos conceitos, que é esse o papel do empreendedor que agora se fala e eu não me identifico mas que esse papel ficou um bocadinho de lado, tento não ficar muito porque acho que temos de estar sempre a inovar, e estamos, fazemos coisas novas, mas agora estou mais centrado no dinheiro, que é horrivel não é" (ES2)

O outro elemento, o entrevistado $n^{\circ} 5$, considera que são diferentes na medida em que possui outros objetivos, mas não está menos motivado.

"Eu diria que são diferentes. Diria que nós trabalhávamos muito na questão de garantir os serviços a algumas pessoas, a partir de agora tem que se começar também a pensar que as próprias pessoas (...) possam garantir e seguir a sua via e por isso é que temos as questões politicas para resolver" (ES5)

\subsubsection{Diferença nas motivações na criação de um empreendimento comercial e social}

No sentido de explorar a perceção que os empreendedores sociais possuem face às diferenças nas motivações para criarem o empreendimento social e o comercial, apenas foram inquiridos os que referiram já ter estado envolvidos anteriormente em iniciativas de empreendedorismo comercial, sendo cinco elementos no total.

A perceção de um dos elementos (nº) é que as motivações são as mesmas na medida em que a sua principal motivação é a vontade de inovar e criar, quer na criação deste empreendimento social quer nos projetos que já esteve envolvida: 
"Sim. Eu gosto de criar coisas (...) a minha motivação é de criar coisas" (ES8)

Os restantes elementos têm a perceção de que são diferentes, na medida em que os projetos de empreendedorismo comercial tiveram por trás uma necessidade de criação de emprego e uma necessidade de obtenção de reconhecimento pessoal, motivações que não estiveram por trás da criação do empreendimento social.

"Então montei o atelier com um amigo na altura, não tínhamos trabalho, ninguém dá trabalho a um miúdo de 18 anos nesta área (...).” (ES1)

"Foram diferentes obviamente. Quando criei os projetos de empreendedorismo comercial que criei, basicamente o meu objetivo era ser inovador, diferente, irreverente, marcar a diferença, era um objetivo mais de reconhecimento de mim mesmo, ou seja, estava numa fase de necessidade de maior afirmação e daí o objetivo mais centrado em mim. Quando comecei o projeto de empreendedorismo social eu já tinha tido a noção de que a solução para a minha realização não passaria necessariamente por satisfazer as minhas necessidades imediatas e de reconhecimento perante a sociedade ou mim mesmo" (ES13) 


\section{V- Discussão e conclusões}

Numa fase inicial deste estudo propusemo-nos a procurar respostas para três questões de investigação, que serviram de base para o percurso desenvolvido em direção a possíveis respostas às questões. Em jeito de síntese, apresentaremos de seguida as grandes conclusões que resultam da análise dos resultados do capítulo anterior e que constituem, desta forma, a resposta às referidas questões de investigação.

\section{1. - Motivação dos indivíduos a iniciarem um empreendimento de âmbito social}

As motivações na criação do empreendimento social encontradas neste estudo, enquadram-se, na sua maioria, em fatores de ordem pull. Como revisto no capítulo II, estes fatores atraem os indivíduos para iniciarem um negócio (Kirkwood \& Walton, 2010) e vimos também que são mais prevalentes do que os fatores push (Segal et al, 2005) o que é relevante uma vez que estes empreendedores motivados por fatores pull têm maior probabilidade de sucesso (Amit and Muller, 1995). Em jeito de síntese, eis os resultados das motivações de ordem pull dos entrevistados na criação do empreendimento social na tabela 18.

\begin{tabular}{|c|c|}
\hline \multicolumn{2}{|c|}{ Motivações dos empreendedores sociais na criação do empreendimento } \\
\hline Fatores pull & Fatores push \\
\hline $\begin{array}{c}\text { Altruísmo } \\
\text { Paixão } \\
\text { Inovar e criar } \\
\text { Oportunidade }\end{array}$ \\
\hline \multicolumn{2}{|c|}{ Fatores relacionados com o trabalho } \\
\hline \multicolumn{2}{|c|}{ Influência de role models } \\
Voluntariado
\end{tabular}




\section{Tabela 18 - Motivações na criação do empreendimento social}

Vale a pena destacar o altruísmo por ter sido a mais referida por todos os empreendedores, isto é, uma vontade de realizar um projeto com ações em benefício dos outros ao invés de efetuar ações para benefício próprio ou com o objetivo de obter qualquer tipo de recompensa externa. Neste sentido, percebemos que embora a sustentabilidade dos projetos seja uma preocupação de todos os empreendedores sociais, a obtenção de lucros para beneficio próprio não é um objetivo para nenhum dos elementos. A paixão também teve enorme relevância nas palavras dos empreendedores sociais, inerente, como já foi referido, o gosto pelo trabalho e pela área onde trabalham. A vontade dos empreendedores sociais de criarem algo novo foi também uma motivação para alguns elementos, sendo que $70 \%$ dos entrevistados se considera criativo e inovador, portanto existe aqui uma certa vontade de fazer as coisas de forma diferente, acreditando que esta inovação pode trazer benefícios aos projetos já que as soluções já existentes no mercado não têm resolvido determinados problemas sociais. O reconhecimento de uma oportunidade foi outro dos fatores de ordem pull que surgiu, sendo que os empreendedores sociais que a referiram foram capazes de agarrar um desafio e desenvolver uma ideia, o que também demonstra que estes indivíduos são capazes de enfrentar desafios e criar novos projetos quando não tinham essa necessidade.

Os fatores motivacionais de ordem push, foram muito pouco significativos, tendo apenas surgido os fatores relacionados com o trabalho, sendo que um dos entrevistados refere ter ingressado no empreendedorismo social por insatisfação com empregos anteriores. Ainda que pouco significativo, isto demonstra que os fatores de ordem push e pull não são mutuamente exclusivos, corroborando as ideias descritas na literatura.

Ainda dentro das motivações no empreendedorismo, associada à teoria da expectativa-valor, encontramos a influência de role models, ou seja, o facto de estes empreendedores sociais terem alguém na família ou no grupo de pares que tenham estado envolvidos em algum tipo de iniciativa empreendedora, serviu de modelo e foi um fator que influenciou na sua motivação para ingressarem no empreendedorismo social. O mesmo se 
pode afirmar da prática de voluntariado, onde a transmissão dos valores e a experiência que os entrevistados tiveram nessas ações, influenciou na motivação para criarem o seu projeto.

Ainda que algumas motivações pareçam ter mais relevância do que outras, não existe aqui uma ordem de importância, todavia isto poderia ser melhor explorado num estudo de ordem quantitativa.

No que diz respeito a outro tipo de motivações que se pensou poderem ter algum tipo de influência na motivação para criar um empreendimento social, na realidade elas não se verificaram neste estudo. A vontade de ser o próprio chefe não é relevante para a maioria dos empreendedores, ainda que possa trazer diversas vantagens atualmente, não foi um motivo na criação do projeto. Embora a propensão ao risco seja uma característica apontada aos empreendedores comerciais, o mesmo não se pode afirmar dos empreendedores sociais já que, na realidade, este não foi um fator de motivação para criar o seu projeto, embora eles tenham atualmente a noção dos riscos que os projetos correm. Na verdade, a maioria não gosta de correr riscos e tenta controlá-los; ainda assim, sabendo ou não dos riscos que iriam correr, demonstram resiliência e motivação para os enfrentarem.

Na mesma lógica, e pensando na teoria da motivação de McClelland, que defende que os empreendedores possuem uma alta necessidade de realização e reconhecimento, neste estudo foi comprovado o contrário relativamente aos empreendedores sociais, já que o reconhecimento pessoal é visto como algo positivo mas não como fator motivador e a realização pessoal já foi atingida por alguns dos entrevistados antes da criação deste projeto, ainda que ele esteja a contribuir de forma muito positiva para a mesma. Para outros elementos, a realização pessoal também não dependeu do projeto porque simplesmente ainda não aconteceu, pois os empreendedores sociais sentem que ainda têm de fazer mais, mostrando assim ambição e motivação para continuar a lutar pelos seus objetivos.

\section{2. - Diferenças entre as motivações para o empreendedorismo social e as motivações para o empreendedorismo tradicional}


A resposta a esta questão envolve duas perspetivas que se complementam. Por um lado, a perceção dos entrevistados anteriormente envolvidos em iniciativas de empreendedorismo comercial, que afirmam haver diferenças nas motivações que os levaram a criar esses projetos e os empreendimentos sociais. Os primeiros tiveram por trás motivações de ordem push, associadas à necessidade de criação de emprego ou de reconhecimento pessoal e a criação dos empreendimentos sociais associadas às motivações já referidas. Ademais, as suas próprias opiniões face a esta questão revelam que existem diferenças na questão da obtenção de lucro (comercial) por aposto à criação de valor social, bem como facto de sentirem que por ser um trabalho que envolve e tem implicações diretas na vida dos públicos-alvo torna-se mais exigente a nível de tempo e disponibilidade emocional.

Por outro lado, os resultados da pesquisa, por confronto com a revisão da literatura, confirmam-nos que existem diferenças nas motivações empreendedoras, embora existam também alguns pontos em comum. Na tabela 19 são explicitadas as motivações de ambos os tipos de empreendedorismo, referindo-se as que são comuns e as que não o são.

\begin{tabular}{|c|c|c|}
\hline Motivação & $\begin{array}{c}\text { Empreendedorismo } \\
\text { comercial }\end{array}$ & Empreendedorismo social \\
\hline Inovar/criar & $\mathrm{x}$ & $\mathrm{x}$ \\
\hline Independência & $\mathrm{x}$ & --- \\
\hline Reconhecimento & $\mathrm{x}$ & $\mathrm{x}$ \\
\hline Roles (modelo) & $\mathrm{x}$ & --- \\
\hline Sucesso financeiro & $\mathrm{x}$ & --- \\
\hline Realização & $\mathrm{x}$ & $\mathrm{x}$ \\
\hline Paixão & $\mathrm{x}$ & $\mathrm{x}$ \\
\hline Fatores relacionados com o \\
trabalho (insatisfação)
\end{tabular}




\begin{tabular}{|c|c|c|}
\hline oportunidade & & \\
\hline Altruísmo & --- & $\mathrm{x}$ \\
\hline
\end{tabular}

Tabela 19 - Diferenças e semelhanças nas motivações entre empreendedorismo comercial e social

À semelhança do que acontece no empreendedorismo comercial, também no empreendedorismo social as motivações para iniciar um empreendimento são mais do tipo pull. Ainda assim, enquanto que no empreendedorismo comercial estas motivações pull estão mais associadas a uma motivação extrínseca, isto é, existe uma maior preocupação com a obtenção de sucesso financeiro, independência e reconhecimento, no empreendedorismo social é um tipo de motivação mais intrínseca, no sentido em que a pessoa não cria o empreendimento com o intuito de obter recompensas externas mas sim pelo interesse pessoal que tem na tarefa empreendedora e por uma preocupação iminentemente altruísta com o bem-estar dos outros. Assim, o esforço que dedicam nas suas tarefas tem objetivos menos centrados em si próprios, mas sim nos outros e nos objetivos concretos do projeto. As experiências que tiveram no passado, imbuíram nestes empreendedores sociais um conjunto de valores que os fizeram optar por esta escolha e por este tipo de trabalho, ao invés de um empreendimento centrado na obtenção de lucro para benefício próprio ou na criação de um trabalho que lhes trouxesse qualquer outro tipo de recompensa externa como reconhecimento ou status, por contraposição à satisfação gerada com aquilo que fazem em prol da sociedade e deles próprios.

\section{3. - O impacto da motivação no processo de desenvolvimento do projeto, nomeadamente, quais são os obstáculos, expectativas e alteração nas motivações ao longo do tempo.}

No capítulo IV já exploramos quais os principais obstáculos enfrentados pelos empreendedores sociais na criação do projeto bem como a forma como foram superados. Ao longo do tempo, e nomeadamente com o crescimento que o projeto foi tendo, os obstáculos cingem-se mais à questão financeira, muito relacionada com o contexto 
socioeconómico atual, à questão da mobilização de recursos humanos e a gestão do tempo. Importa realçar que é na forma como as dificuldades têm sido ultrapassadas, na procura de soluções alternativas e inovadoras, que percebemos que houve desde o início da criação do empreendimento e continua a existir atualmente, uma capacidade de luta e uma motivação cada vez maior para continuar e enfrentar estes obstáculos. Se é verdade que a maioria dos indivíduos não estava preparado para os enfrentar, é também referido que avançariam na mesma com o projeto se tivessem tido conhecimento dessas mesmas dificuldades. A motivação sofre alteração ao longo do tempo na medida em que o impacto das dificuldades enfrentadas não é relevante ao ponto de os desmotivar mas tem, de certa forma, um efeito contrário - a motivação é maior. Na verdade, isto é explicitado mesmo nas suas palavras quando referem que as dificuldades não terão impacto na vontade de um empreender social que queira hoje iniciar um projeto, principalmente se isso estiver dependente da sua motivação e autodeterminação, ou seja, se estas existirem, as dificuldades não serão um mote para não avançar com o projeto. A explicação poderá estar no facto de a maioria dos empreendedores sociais terem a perceção de que o seu projeto está a ser bem-sucedido e de que as suas expectativas foram superadas. Os elementos que não consideram ser ainda bemsucedidos, referem que não o são porque ainda têm de fazer mais, isto é, procuram na sua ação continuada o alcance desse sucesso, que acreditam ser possível chegar com este projeto. Além disso, também o facto de terem adquirido novas competências com a sua experiência pessoal e profissional, como a capacidade de resiliência, humildade e empatia perante o outro e paixão pelo trabalho, competências que consideram essenciais num potencial empreendedor social, aumenta a sua crença de que estão mais capazes de continuar o projeto e desejar dar resposta a objetivos ainda mais ambiciosos.

Ou seja, como diz a teoria da expectativa-valor, as expetativas que a pessoa possui sobre o sucesso, as crenças sobre a capacidade para ser bem-sucedido e as motivações que o leva a querer ser empreendedor definem o seu comportamento (Eccles \& Wigfield, 2002).

Por isso percebemos que os únicos motivos que os fariam desistir do seu empreendimento seriam, na sua maioria, razões de falta de saúde ou algum problema familiar, problemas financeiros graves que os impedissem de pagar as contas ou a intenção de realizar novos projetos nesta área. 


\subsection{Reflexão final}

A presente dissertação pretende contribuir para o conhecimento do fenómeno do empreendedorismo social, e espera-se que uma das implicações práticas seja a de ajudar potenciais interessados no desenvolvimento de um projeto social. Contribui para esse conhecimento através de alguns casos reais de empreendedorismo social com exemplos de projetos e de empreendedores sociais que nos falam, nas suas entrevistas, de todo o processo de criação de um projeto social, do ponto de vista mais pessoal.

Contribui, claramente, para aquele que foi o principal objetivo do estudo, conhecer as motivações no empreendedorismo social, ou seja, explorar as motivações que levam os empreendedores sociais a se envolverem nestas aventuras e prosseguirem, ainda que com obstáculos e desafios, com os seus projetos. Concluímos que estas motivações estão muito relacionadas por um lado, com o perfil da pessoa, na medida em que poderá ter um interesse pessoal por esse trabalho e uma missão altruísta na procura do bem-estar do outro e, por outro lado, estará muito relacionado também com as suas experiências anteriores (de voluntariado por exemplo), as suas aprendizagens e expectativas. A sua crença de que é possível que os outros com quem trabalham mudem, ou seja, a criação de impacto social, objetivo para o qual criam os seus projetos, fá-los estar ainda mais motivados. Definitivamente, neste estudo, a geração de lucro não é um objetivo primordial para o empreendedor social, embora exista um desafio em todos os projetos, o de garantir a sua sustentabilidade. Assim, a motivação parece ter um impacto enorme na prossecução dos objetivos dos empreendedores e no sucesso das suas iniciativas.

Ademais, traz uma perspetiva de quais são os principais obstáculos na criação e desenvolvimento de um empreendimento social, tendo sido destacados a mobilização de recursos humanos e financeiros e a gestão do tempo, as principais competências necessárias ao empreendedor social como por exemplo o facto de ter que se ter persistência, capacidade de liderança e empatia, bem como algumas recomendações a quem queira hoje iniciar um projeto deste âmbito, nomeadamente o reforço pela resiliência necessária para obter sucesso. 
Este estudo levanta ainda questões e ideias que poderão ser discutidas pelos políticos na construção de novas políticas de apoio a empresas sociais e pelos gestores e empreendedores na gestão dos seus projetos, como por exemplo, o networking, isto é, a criação de redes e de sinergias entre as pessoas e os projetos.

Acredita-se ainda que, este estudo, ao trazer exemplos concretos de empreendedorismo social e do sucesso e motivação que os entrevistados demonstram, poderá contribuir para que outros ganhem motivação para avançar com os seus projetos. A visibilidade que o empreendedorismo social tem neste momento não pode passar apenas por uma "moda" mas por trazer, realmente, verdadeiras soluções para os problemas. Não necessitam ser novas, podem ser replicadas tendo em conta o que já existe.

Por fim, é também um reconhecimento ao maravilhoso trabalho que tem sido feito ao nível de empreendedorismo social, concretamente aos projetos que temos aqui tão perto!

\subsection{Limitações do estudo e sugestões para investigações futuras}

Esta investigação, sendo de âmbito qualitativo, teve como método de recolha de dados a utilização de entrevistas. Este método tem algumas limitações na medida em que pode conduzir a respostas ambíguas e não totalmente verdadeiras, já que a presença do entrevistador pode inibir o entrevistado. Ademais, o facto de ter sido efetuado um limitado número de entrevistas, não permite tirar conclusões generalistas e representativas do ponto de vista estatístico. Neste sentido, através do uso de uma amostra maior poderia ser realizado um estudo com uma abordagem quantitativa que permitisse efetuar generalizações e validar as conclusões aqui obtidas. Uma amostra mais alargada de empreendedores sociais poderia permitir validar com mais precisão as conclusões desta investigação.

Dada a crescente importância que o empreendedorismo social tem tido, outros temas poderiam merecer uma investigação, nomeadamente o impacto social que as práticas de empreendedorismo social têm tido na sociedade ou a avaliação e a perceção que os empreendedores sociais têm do sucesso do seu projeto e em que medida ele influencia as suas motivações. 
Ademais, este estudo foca-se apenas em empreendedores sociais a atuar em Portugal e, tendo em conta que o contexto, nomeadamente, os níveis de empreendedorismo dos países e os seus recursos, podem influenciar a propensão para os processos de empreendedorismo nos quais as pessoas se envolvem, seria interessante que investigações futuras pudessem fazer uma comparação das diversas motivações nos diferentes países e assim, obter uma perspetiva mais alargada sobre o tema e a influência que o contexto socioeconómico pode ter na motivação. 


\section{Bibliografia}

Aldrich, H. (2000). Organizations evolving. Beverly Hills: Sage.

Amit, R. e Muller, E. (1995), "Push and pull entrepreneurship (two types based on motivation)", Journal of Small Business and Entrepreneurship, Vol. 12 No. 4, pp. 64-80.

Austin, J., Stevenson, H., e Wei-Skillern, J. (2006). "Social and commercial entrepreneurship: Same, different, or both?”, Entrepreneurship Theory \& Practice, Vol. 30 No.1, pp. 1-22.

Bardin, L. (1997), Análise de Conteúdo, Lisboa: Edições 70.

Beardwell, I., Holden, L. e Claydon, T. (2004), Human Resource Management - A contemporary approach. Great Britain: Prentice Hall.

Bogdan, R. e Biklen, S. (1994), Investigação Qualitativa em Educação - Uma introdução à teoria e aos métodos. Porto: Porto Editora.

Borkowski, N. (2009), Organizational Behavior, Theory and Design in Healthcare, London: Jones and Bartlett Publishers

Brooks, A. (2009). Social entrepreneurship: A modern approach to social value creation. Upper Saddle River, NJ: Pearson-Prentice Hall.

Bygrave, W. e Zacharakis, A. (2011), Entrepreneurship, New Jersey: Wiley.

Carson, D., Gilmore, A., Perry, C. e Gronhaug, K. (2001), Qualitative Marketing Research, London: Sage Publications. 
Carsrud, A., e Brannback, M. (2011). "Entrepreneurial Motivations: What Do We Still Need to Know?", Journal of Small Business Management, Vol. 49 No.1, pp. 9-26.

Carter, N. M., W. B. Gartner, K. G. Shaver e E. J. Gatewood (2003), "The career reasons of nascent entrepreneurs", Journal of Business Venturing, Vol. 18, pp. 13-39.

Certo, S. e Miller, T. (2008), "Social Entrepreneurship: Key issues and concepts”, Business Horizons, No 51, pp. 267-271

Dacin, P., Dacin, M. e Matear, M. (2010), “Social entrepreneurship: Why we don't need a new theory and how we move forward from here", Academy of Management Perspectives, pp.38-57

Davis, S. (2002), "Social Entrepreneurship: Towards an entrepreneurial culture for social and economic development", International Board Selection Committee, Ashoka: Innovators for the Public, pp. 1-34.

de Bruin, A., Brush, C. e Welter, F. (2007), “Advancing a framework for coherent research on women's entrepreneurship", Entrepreneurship Theory and Practice, Vol. 31 No.3, pp. $323-40$.

Dees, G. (1998). "The meaning of social entrepreneurship". Retirado de http://www.caseatduke.org/documents/dees_sedef.pdf

Dorado, S. (2006). "Social entrepreneurial ventures: different values so different process of creations, no?", Journal of Developmental Entrepreneurship, pp. 319-343. 
Drost, E. (2012), “A Model of Entrepreneurship Education and Entrepreneurial Intention", EURAM 12 $2^{\text {th }}$, Rotterdam, pp. 1-28.

Drucker, P. (1999). Innovation and Entrepreneurship, Butterworth-Heinemann, Oxford.

Dunkelberg, W., Moore, C., Scott, J. e Stull, W. (2012), "Do entrepreneurial goals matter? Resource allocation in new owner-managed firms", Journal of Business Venturing, pp.1-16

Eccles, J. S., A. Wigfield e U. Schiefele (1998), "Motivation to succeed", in W. Damon e N. Eisenberg, Handbook of child psychology, 5th edition, Vol. 3, pp.1017-1095.

Eccles, J. S. e A. Wigifield (2002), "Motivational, beliefs, values, and goals", Annual Review of Psychology, Vol. 35, pp. 109-132.

Edelman, L.F., Brush, C.G., Manolova, T.S. e Greene, P.G. (2010), "Start-up Motivations and Growth Intentions of Minority Nascent Entrepreneurs". Journal of Small Business Management, Vol. 48, No. 2, pp.174-196

Edmondson, A. and McManus, S. (2007), "Methodological fit in management field research", Academy of Management Review, Vol. 32 No. 4, pp. 1155-1179.

Giacomin, O., Janssen, F., Pruett, M., Shinnar, R., Llopis, F. e Toney, B. (2011), "Entrepreneurial intentions, motivations and barriers: Differences among American, Asian and European students", International Entrepreneurship Management Journal, Vol 7, pp. 219-238 
Guia Prático do Empreendedor (2012), http://www.ei.gov.pt/files/institucional/5guiapraticoempreendedor.pdf, acedido a 15 de janeiro de 2012.

Hall, K., Miller, R. e Millar, R. (2012), “Jumped or pushed: what motivates NHS staff to set up a social enterprise?", Social Enterprise Journal, Vol.8, pp. 49-62

Haugh, H. (2007), "New strategies for a sustainable society: the growing contribution of social entrepreneurship", Business Ethics Quartely, Vol. 17, pp.743-749

Hechavarria, D., Renko, M. e Matthews, C. (2012), “The nascent entrepreneurship hub: goals, entrepreneurial self-efficacy and start-up comes", Small Business Economics, Vol. 39, pp. 685-701

Hessels, J., Gelderen, M. e Thurik, R. (2008), "Entrepreneurial aspirations, motivations, and their drivers". Small Business Economy, Vol. 31, pp. 323-339.

Hisrich, R., M. Peters e D. Shepherd (2010), Entrepreneurship, 8th Edition, McGraw Hill International Edition.

Instituto de Empreendedorismo Social (2013), "Empreendedorismo Social", http://www.ies.org.pt/conhecimento/empreendedorismo_social/, acedido a 2 de janeiro de 2013.

Gummesson, E. (2005), “Qualitative research in marketing: Road-map for a wilderness of complexity and unpredictability", European Journal of Marketing, Vol. 39, Iss: 3 pp.309327

Kelly, D. J., N. Bosma e J. E. Amorós (2011), “Global Entrepreneurship Monitor: 2010 Global Report", Global Entrepreneurship Monitor. 
Kirkwood, J. (2009),"Motivational factors in a push-pull theory of entrepreneurship", Gender in Management: An International Journal, Vol. 24 No.5, pp. 346 - 364

Kirkwood, J. e Walton, S. (2010), "What motivates ecopreneurs to start businesses?", International Journal of Entrepreneurial Behavior \& Research, Vol. 16 Iss: 3, pp.204-228

Kirzner, I. (1973). Competition and entrepreneurship. Chicago: University of Chicago Press.

Krueger, N. e Brazeal, D. (1994), "Entrepreneurial Potential and Potential Entrepreneurs", Entrepreneurship Theory and Practice, pp.91-104.

Leadbeater, C. (1997), The Rise of the Social Entrepreneur, Demos, London.

Locke, E. A. (2000), "Motivation, cognition, and action: and analysis of studies of task goals and knowledge", Applied psychology: An International Review, Vol. 49, $\mathrm{N}^{\circ} 3$, pp. 408-429.

Mair, J. e Noboa, E. (2003). "Social entrepreneurship: How intentions to create a social enterprise get formed” (Working Paper \#521). Barcelona, Spain: IESE Business School.

Mair, J. and Noboa, E. (2005), "How Intentions to Create a Social Venture Are Formed - A case study", IESE Business School, No 593, pp. 1-29

Mair. J e Martí, I. (2006), "Social entrepreneurship: A source of explanation, prediction and delight", Journal of World Business, No 41, pp. 36-44 
Marques, C., Ferreira, J., Ferreira, F. e Lages, M. (2012), "Entrepreneurial orientation and motivation to start up a business: evidence from the health service industry. Entrepreneurship Management Journal”, New York, published online: 22 december.

Milliken, J. (2001), "Qualitative research and marketing management", Management Decision, Vol. 39 Iss: 1, pp. 71-78

Miller, T., Grimes, M., McMullen, J. e Vogus, T. (2012), "Venturing for others with heart and head: How compassion encourages social entrepreneurship". Academy of Management Review, Vol.37 No.4, pp. 616-640.

Moore, C. (2009), "Exploring the Social Entrepreneur: Individual and Organizational Identity Construction", Investigação - Trabalhos em curso, Paper 148, Marquette University

Moran, C. M., Diefendorff, J.M., Kim, T.Y. e Liu, Z.Q. (2012), “A profile approach to selfdetermination theory motivations at work". Journal of Vocational Behavior, Vol. 81, pp354-363

Moreira, C. D. (1994), Planeamento e Estratégias da Investigação Social, Lisboa: Instituto Superior de Ciências Sociais e Politicas.

Mulgan, G. e Landry, L. (1995), “The Other Invisible Hand: Remaking Charity for the $21^{\text {st }}$ Century", Demos/Comedia, London.

Naffziger, D.W., Hornsby, J.S., e Kuratko, D.F. (1994), “A Proposed Research Model of Entrepreneurial Motivation”. Entrepreneurship Theory and Practice, pp. 29-42. 
Nga, J. e Shamuganathan, G. (2010), "The influence of personality traits and demographic factors on social entrepreneurship start up intentions”, Journal of Business Ehtics, 95, pp. 259-282

Parente, C., Lopes, A. e Marcos, V. (2012), "Defining Social Entrepreneurship: Lessons from Portuguese Organizational Dynamics", Tenth International Conference of the International Society for Third-Sector Research Siena, pp.1-27

Quivy, R. e Campanhoudt, L. (2008). Manual de Investigação em Ciências Sociais, Lisboa: Gradiva.

Qu, S. Q. e Dumay, J. (2011), “The Qualitative Research Interview”, Qualitative Research in Accounting \& Management, Vol. 8 No. 3, pp. 1 - 51.

Rahman, K. e Rahman, S. (2011), "Entrepreneurship needs and achievement motivations of descendant Latin-Japanese entrepreneurs in Japan”, International Journal of Entrepreuneurship, Vol. 15, pp. 99- 119

Rubio, A., Aragon, A. e Esteban, N. (s/d), "How distinct social entrepreneurship is from commercial entrepreneurship", Investigação - Trabalho em curso, project 11837/PHCS/09 of Fundación Séneca, Región de Murcia.

Schumpeter, J. A. (1934), The Theory of Economic Development. Cambridge, MA: Harvard University Press.

Segal, G., Borgia, D. e Schoenfeld, J., (2005),"The motivation to become an entrepreneur", International Journal of Entrepreneurial Behaviour \& Research, Vol. 11 Iss: 1 pp. 42 - 57 
Seelos, C. e Mair, J. (2005), "Social Entrepreneurship: Creating new business models to serve the poor", Business Horizons, Vol. 48, pp. 241-246

Sen, P. (2007), “Ashoka's big idea: Transforming the world through social entrepreneurship", Futures, No 39, pp.534-553

Shane, S. e S. Venkataraman (2000), "The promise of entrepreneurship as a field of research", Academy of Management Review, Vol. 25, № 1, pp. 217-226.

Shane, S., Locke, E.A. e Collins, C. (2003), "Entrepreneurial motivation", Human Resource Management Review, Vol. 13, pp. 257-79.

Shaw, E.; Carter, S., (2007), "Social entrepreneurship: Theoretical antecedents and empirical analysis of entrepreneurial processes and outcomes". Journal of Small Business and Enterprise Development, Vol. 14 No.3, pp. 418 - 434

Steinerowski, A., Jack, S. e Farmer, J. (2008), "Who are the social entrepreneurs and what do they actually do?", Frontiers of Entrepreneurship Research, Babson College Entrepreneurship Research Conference (BCERC ), Vol. 28: Iss. 21, Article 2.

Sud, M.; VanSandt, C. e Baugous, A. (2009), "Social Entreprenership: the role of Institutions", Journal of Business Ethics, Vol.85, pp. 201-216

Thompson, J., Alvy, G. e Lees, A. (2000), "Social entrepreneurship - a new look at the people and the potential". Management Decision, Vol. 38 No. 5, pp. 328-38.

Thompson, J. (2002), “The world of the social entrepreneur", International Journal of Public Sector Management, Vol. 15 Iss: 5 pp.412-431 
Thompson, J. (2004), "The facets of the entrepreneur: identifying entrepreneurial potencial", Management Decision, Vol. 42, pp. 243-258

Thompson, J. e Doherty, B. (2006), "The diverse world of social enterprise: A collection of social enterprise stories", International Journal of Social Economics, Vol. 33 Iss: 5, pp. $361-375$

Whitman, J. (2011). "Social Entrepreneurship: An Overview". In Bygrave, W. \& Zacharakis, A., Entrepreneurship (pp.564-582). New Jersey: Wiley.

Williams, N. e Williams, C. (2012), "Evaluating the socio-spatial contingency of entrepreneurial motivations: A case study of English deprived urban neighbourhoods", Entrepreneurial \& Regional Development: An International Journal, Vol. 24, pp. 661-684

Wilson, F., Kickul, J. e Marlino, D. (2007), "Gender, Entrepreneurial Self-efficacy and Entrepreneurial Career Intentions: Implications for Entrepreneurship Education", Entrepreneurship Theory and Practice, pp. 387-406.

Yunus, M. (2010), Building Social Business - The new kind of capitalism that serves humanity's most pressing needs, Editorial Presença: Lisboa.

Zahra, S. E., Gedajlovic, E., Neubaum, D. O., \& Shulman, J. M. (2009). “A typology of social entrepreneurs: Motives, search processes and ethical challenges". Journal of Business Venturing, Vol. 24 No.5, pp. 519-532. 


\section{Anexos}

\section{Guião de entrevista}

Identificação dos empreendedores sociais

Nome

Idade

Género

Habilitação académica

Situação profissional anterior/atual

Profissão anterior

Data de início do projeto

Aufere de salário com o empreendimento ou obtém rendimentos por outra via

Q1. Quando teve início a sua prática empreendedora e em que iniciativas já esteve, ou não, envolvido.

Q2. Como surgiu a vontade de ser empreendedor?

Q3. Que projeto criou? (objetivos, missão, trabalho desenvolvido; pessoas assalariadas, voluntários envolvidos, como se financia o projeto, evolução em termos financeiros, clientes...).

Q4. Quais foram as suas principais motivações na criação deste projeto?

Q5. As motivações que teve para criar o seu projeto mantêm-se hoje em dia ou alteraramse?

Q6. Sempre teve expectativas de ter o seu próprio empreendimento? Foi algo planeado? 
Q7. Quais eram as suas expectativas iniciais face à criação do projeto? Foram cumpridas?

Q8. Acha que existem diferenças entre um empreendedor comercial e um empreendedor social? Quais?

Q9. Já esteve envolvido na criação de algum projeto de empreendedorismo comercial? Se sim, que motivações teve para o criar? São diferentes das que teve para criar este projeto?

Q10. (se tiver respondido que não na questão 9) Porque criou uma iniciativa social e não comercial?

Q11. Sente que é uma pessoa criativa? E inovadora? Porquê?

Q12. Sente que o facto de ter o seu próprio projeto lhe confere um reconhecimento que não teria anteriormente? Esta também foi uma motivação para criar este projeto? E hoje em dia serve como fator motivador?

Q13.Possui outras pessoas na família/próximas que tenham criados projetos empreendedores? (Ou outros empreendedores). Sente que isso influenciou de alguma forma a sua vontade de prosseguir com um projeto próprio?

Q14. Antes de criar o seu projeto já fez voluntariado nesta área? E atualmente? Isso influenciou de alguma forma o projeto em que se envolveu?

Q15. Acha-se bem-sucedido? Porquê?

Q16. Sente-se realizado? A sua realização pessoal e/ou profissional esteve dependente da criação deste projeto? 
Q17. O que acha de ser o seu próprio chefe?

Q18. Sente que há forte risco associado a este projeto? Que outras situações na sua vida considera terem sido situações em que correu risco? Gosta de correr riscos?

Q19. Principais obstáculos com que se deparou no início da criação do projeto? E hoje em dia? Como tem ultrapassado esses obstáculos?

Q20. Estava preparado para enfrentar essas dificuldades? Se não estava, e se hoje soubesse que iria enfrentar essas dificuldades, avançaria com o projeto na mesma?

Q21. Acha que esses obstáculos são suficientemente fortes para inviabilizar as motivações de um potencial empreendedor social?

Q22. Quais acha que devem ser as capacidades e competências de um empreendedor social para obter sucesso? Sente que sempre as teve ou foi algo que adquiriu com o tempo? (Como adquiriu essas competências?)

Q23. O que recomendaria a outros empreendedores sociais?

Q24. O que mudou em si? Que efeitos teve e o que tem representado para si ser um empreendedor social?

Q25. Razões que o poderiam levar a abandonar a prática.

Q26. Quais considera serem os aspetos positivos e negativos de ser um empreendedor social? 